\title{
PIRÓLISE DA TURFA E ANÁLISE DO SEU CARVÃo
}

\section{DIMAS AGOSTINHO DA SILVA}

Engenheiro Florestal

Orientador: Prof. Dr. JOSẼ OTĀVIO BRITO

Dissertação apresentada à Escola Superior de Agricultura "Luiz de Queiroz", da Iniversidade.de São Paulo, para obtenção do título de Mestre em Engenharia Florestal.

P I R.A.C I C A B A

Estado de São Paulo - Brasil

Dezembro - 1987 


$$
\begin{aligned}
& \text { Silva, Dimas Agostinho da } \\
& \text { Pirólise da turfa e análise do seu carvão. }
\end{aligned}
$$
Piracicaba, 1987.

$121 \mathrm{p}$.

$$
\text { Diss.(Mestre) - ESALQ }
$$

Bibliografia.

- 1. Carvão vegetal - Análise 2. Energia - Fonte alternativa 3. Turfa - Carbonỉzação 4. Turfa em e nergia I. Escola Supérior de Agricultura Luiz de Queiroz, Piracicaba

$$
\text { CDD } 662.74
$$


Aprovado en: 12/02/88

Comissão julgadora

Prof. Dr. José Otāvio Brito

ESALQ/USP

Prof. Dr. Luiz Ernesto Geroge Barrichelo

ESALQ/USP

Dr. Walter Suiter Filho

CAFSB/MG

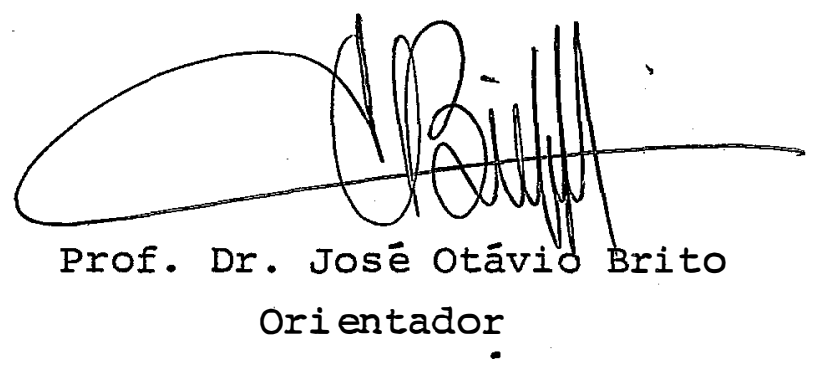


Este trabalho

Ofereço à

- meus pais: Toninho e Alacoque

- meus irmãos: Myrian, Fatinha, Célia, Célio, Mariza, Dirceu, Mônica e. Toninha

- meus sobrinhos: Camila, Paula, Rodrigo, Armindinho, Eugenia e Arminda

- meus cunhados: Zé do Carmo, Miguel, Dinha, Henrique, Ālva ro, Fátima e Arrmindo

- meus avós (in memorian): Joaquim, Antônia, Bironga e Francisca

- amizade de: família Williams Valentim, irmã Lavinha e membros do movimento focolaris

- meu recanto preferido: Madre de Deus de Minas

Dedido à Lourdes e ao Diminhas

Louvo. à Deus e a Nossa Senhora Aparecida 


\section{AGRADECIMENTOS}

- Ao Prof. Dr. José otívio Brito, de maneira muito especial, pelo incentivo, apoio e orientação;

- ao Prof: Dr. Hilton Thadeu Zarate do Couto, pello auxilio na análise estatística;

- ao Prof. Dr. Luis Ernesto George Barrichelo pela cooperação, incentivo e sugestões;

- aos colegas da Pós-Graduação em Engenharia Florestal pela convivência e incentivo;

- à Enga Ftal. Vera Lex Engel pela colaboração e versão do resumo para o inglês;

- aos colegas do INPA, pelo incentivo e amizade;

- às bibliotecárias Marialice M. Poggiani, Odair T.Meneghtti de Paris, Silvana M. Gregorio e Sonia C. da Rocha pela ajū da nas consultas e revisão bibliográfica;

- ao Técnico Udemilson Luis Ceribelli e Rudney Siviero pela ajuda nas análises laboratoriais;

- aos funcionários, Beatriz Regina Duarte Novaes, João Luís Duarte Novaes e Maria Regina Buch, pela colaboração e apoio; 
- aos professores, funcionários e estagiários do Departamento de Ciēncias Florestais e do IPEF, em especial do Setor de Quimica, Celuinse e Energia, pela convivência e auxi1io;

- ao Ministério da Ciēncia e Tecnologia, CNPq e INPA pela oportunidade;

- à Escola Superior de Agricultura "Luiz de Queiroz"/USP, pe la realização do curso;

- à Cerâmica Criciuma e Mineradora Conventos pela cessão de material;

- ao Prof: Dr. Carlos Celmente Cerri pela ajuda nas análises;

- ao Engo Saulo de Luca pelo apoio na coleta do material;

- à cidade de Piracicaba, pela acolhida;

- à SONAR - Serviços de Datilográfia S/C Ltda., pelo serviço datilogrāfico;

- à todos que de uma maneira ou de outra contribuiram para a realização deste trabalho. 
-vi.

I N D I C E

página

IISTA DE TABELA $\ldots \ldots \ldots \ldots \ldots \ldots \ldots \ldots \ldots \ldots \ldots \ldots \ldots \ldots \ldots \ldots$

viii

IISTA DE FIGURA $\ldots \ldots \ldots \ldots \ldots \ldots \ldots \ldots \ldots \ldots \ldots \ldots \ldots \ldots \ldots \ldots \ldots$

xi

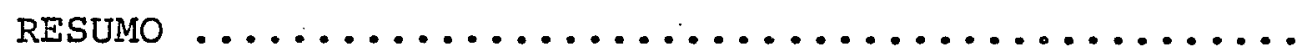

xiii

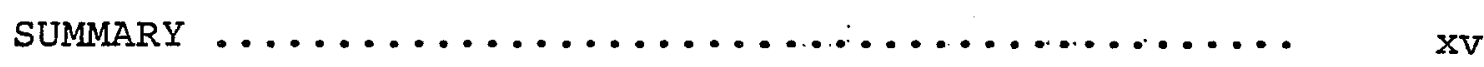

1. INTRODUÇÃo $\ldots \ldots \ldots \ldots \ldots \ldots \ldots \ldots \ldots \ldots \ldots \ldots \ldots \ldots$

2. REVISÃo $\ldots \ldots \ldots \ldots \ldots \ldots \ldots \ldots \ldots \ldots \ldots \ldots \ldots \ldots \ldots \ldots \ldots \ldots \ldots$

2.1. Caracteristica da turfa .............. 6

2.2. Disponibilidade e formas de exploração ..... 10

2.3. Comportamento da turfa frente ao processo de pirólise ........................ 13

2.3.1. Rendimento dos produtos .......... 13

2.3.2. Caracteristica do carvão ......... 21

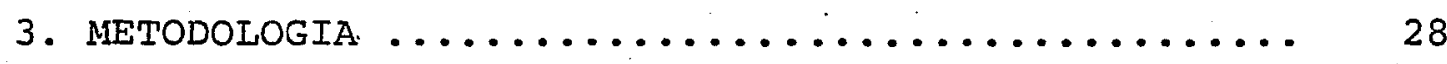

3.1. Preparo e caracterização da turfa ......... 30

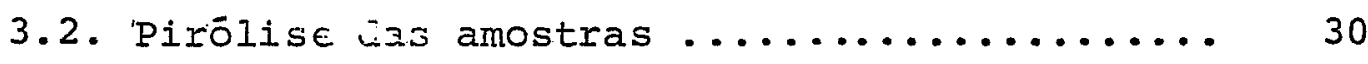

3.3. Avaliação do rendimento e taxa de redução granulométrica da turfa na Firöliss ...... 32

3.4. Análises do carvão de turfa ........... 34

3.5. Delineamento estatístico ............. 35

4. RESULTAdOS E DISCUSSÃo .................... 38 
.vii.

página

4.1. Caracterização da turfa $\ldots \ldots \ldots \ldots \ldots \ldots \ldots .38$

4.2. Resultados da firólise cia turfa ......... 39

4.3. Taxa de redução granulométrica da turfa .... 53

4.4. Caracteristicas do carvão de turfa ........ 59

4.4.1. Densidade e porosidade do carvão .... 59

4.4.2. Poder calorifico superior do carvão.. 70

4.4.3. Análise imediata do carvão ........ 78

5. CONCLUSÕES $\ldots \ldots \ldots \ldots \ldots \ldots \ldots \ldots \ldots \ldots \ldots \ldots . \ldots \ldots$

6. REFERENCIAS BIBLIOGRAFICAS $\ldots \ldots \ldots \ldots \ldots \ldots \ldots . .65$

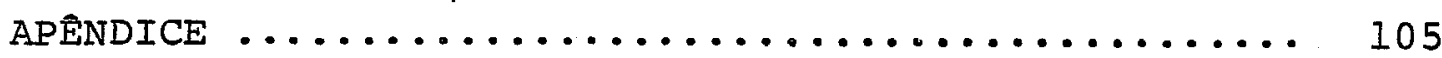


LISTA DE TABELAS

TABELA NO

pägina

01 Discriminação de turfa baseada principalmente no grau de decomposição e na quantidade

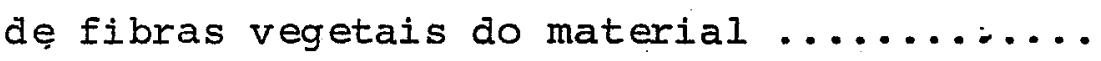

02 Recursos identificados de determinadas turfeiras em alguns Estados brasileiros.......

03 Esquema de análise de variância empregado nos

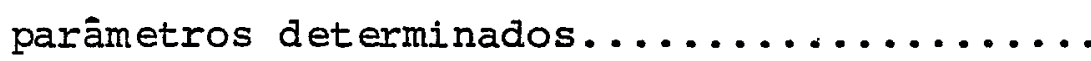

Caracterização da turfa $\ldots \ldots \ldots \ldots \ldots \ldots \ldots$

05 Resultados médios da pirólise da turfa em rendimento gravimétrico...............

Valores de $\mathrm{F}$ para rendimento gravimétrico dos produtos da pirólise da turfa ............

07 Comparação das médias de rendimento gravimétrico dos produtos da turfa em função da tem peratura final e taxa de aquecimento........

08 Comparação de médias de rendimento gravimētrico em carvão de turfa e voláteis conden sāveis em função da temperatura final e tem-

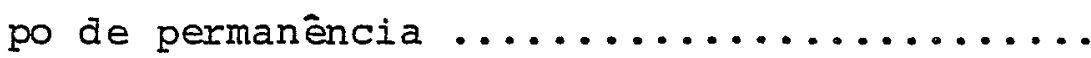

09 Comparação de médias de rendimento gravimētrico de carvão de turfa em função da taxa de aquecimento e tempo de permanência....... 
10 Resultados médios da taxa de redução granulo métrica da turfa frente à pirólise.........

11 Valores de $F$ para taxa de redução granulométrica da turfa frente à pirólise ..........

12 Comparação de médias para taxa de redução granulométrica da turfa frente à interação taxa de aquecimento e temperatura final.....

13 Resultados médios de densidade e porosidade do carvão de turfa..$\ldots \ldots \ldots \ldots \ldots \ldots \ldots \ldots$

14 Valores de $F$ para densidade e porosidade do carvão de turfa $\ldots \ldots \ldots \ldots \ldots \ldots \ldots \ldots \ldots \ldots$

15 Comparação de medidas de densidade verdadeira, densidade aparente e porosidade do carvão de turfa em função da temperatura final

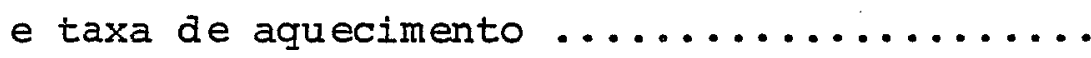

16 Resultados médios do poder calorifico superior do carvão de turfa.................

17 Valores de $F$ para poder calorifico superior do carvão de turfa..................

18 Comparação de médias do poder calorífico superior do carvão de turfa em função de cada fator testado na pirólise ................

19 Resultados médios da análise imediata do cạ vão de turfa $\ldots \ldots \ldots \ldots \ldots \ldots \ldots \ldots \ldots \ldots \ldots$ 
20 Valores de $F$ para anālise imediata do carvão de turfa .......................... 80

21 Comparação de médias do teor de matérias voläteis do carvão de turfa em função da tempe ratura final e taxa de aquecimento .........

22 Comparação de mëdias do teor de matérias volāteris e de cinzas do carvão de turfa em função da temperatura final e tempo de perma

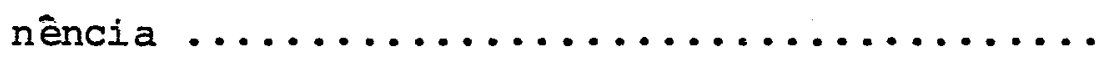

23 Comparação de mëdias de anälise imediata do carvão de turfa em função da taxa de aquecimento e tempo de permanência ............ 


\section{IISTA DE FIGURAS}

FIGURA NO

pāgina

01 Representação esquemātica do equipamento usa

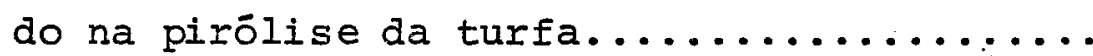

02 Efeito da taxa de aquecimento, temperatura final e tempo de permanência no rendimento gravimëtrico do carvão de turfa

03 Efeito da taxa de aquecimento, temperatura final e tempo de permanência no rendimento gravimétrico de volāteis condensāveis ......

04. Efeito da taxa de aquecimento, temperatura final e tempo de permanēncia no rendimento gravimētrico de volāteis não condensãveis...

05 Efeito da taxa de aquecimento e temperatura final na taxa de reaução granulomētrica da turfa .........................

06 Efeito da taxa de aquecimento e temperatura final na densidade verdadeira do carvão de turfa .........................

07 Efeito da taxa de aquecimento e temperatura final na densidade aparente do carvão de

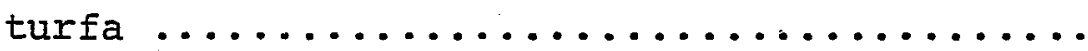

08 Efeito da taxa de aquecimento e temperatura final na porosidade do carvão de turfa...... 
09 Efeito da taxa de aquecimento e temperatura final no poder calorifico superior cio carvão

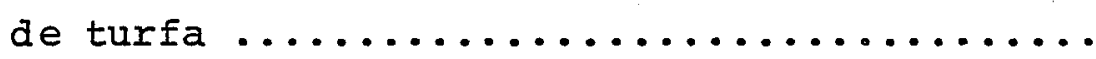

10 Efieito do tempo de permanência e temperatura final do poder calorifico superior do carvão

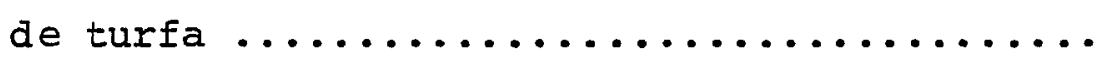

11 Efeito da taxa de aquecimento, temperatura final e tempo de permanência no teor de matérias voláteis do carvão de turfa ........

12 Efeito da taxa de aquecimento e temperatura final no teor de cinzas do carvão de turfa.

13 Efeito da taxa de aquecimento, temperatura final e tempo de permanencia no teor de car

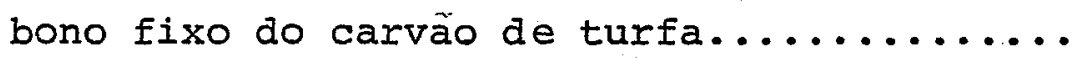




\title{
PIRÓLISE DA TURFA E ANALISE DO SEU CARVÃO
}

\author{
Autor: DIMAS AGOSTINHO DA SILVA \\ Orientador: Prof. Dr. JOSE ETĀVIO BRITO
}

RESUMO

o presente trabalho objetivou o estudo do com portamento de turfa frente a pirólise, visando averiguar os efeitos da temperatura final, da taxa de aquecimento edo tem po de permanência na temperatura final no rendimento do produtos sólidos (carvão), voláteis condensáveis e voláteis não-condensāveis e nas características do carvão obtido. ES tas caracteristicas foram densidade verdadeira, densidade aparente, porosidade, poder calorifico superior, teores de materiais voláteis, de cinzas, de carbono fixo e tambēm a tạ xa de redução granulométrica.

Procedeu-se a pirölise da turfa em retorta elētrica de laboratório empregando as temperaturas de 300 , $450,600,750$ e $900^{\circ} \mathrm{C}$, às taxas de aquecimento de 1,3 e $5^{\circ} \mathrm{C} /$ minuto e tempo de permanência na temperatura final de 30 e 90 minutos. 
testados na pirólise de turfa, a temperatura final proporcio nou maior efeito na variação dos rendimentos gravimētricos dos produtos e características analisadas no seu carvão. No geral, a turfa originalmente classificada acima de $10 \mathrm{~mm}$ sofreu redução nessa granulometria a níveis de 40-45\% após a pirólise. Quanto maior a temperatura final de pirölise, maior foi o rendimento em voläteis, densidade verdadeira, a densidade aparente, o poder calorifico superior, o teor de cinzas e o teor de carbono fixo, enquanto foi menor o rendimento gravimétrico e o teor de matérias voláteis do carvão de turfa. A porosidade do carvão de turfa foi o parâmetro que apresentou-se menos influenciado pelos fatores testados. o poder calorífico superior foi correlacionado positivamente com a produção de vóláteis durante a pirólise e com o teor de carbono fixo do carvão de turfa. A obtenção do carvão de turfa é viāvel com possibilidades mūltiplas de aplicações, dạ das as diferentes caracteristicas obtidas. 


\title{
PYROLISIS OF PEAT AND ANALYSIS OF ITS COAL
}

\author{
Author: DIMAS AGOSTINHO DA SILVA \\ Adviser: Prof. Dr. JOSĒ OTĀVIO BRITO
}

SUMMARY

This paper has the objective of studying the behavior of peat in face of pyrolisis, towards checking the effects of final temperature, rate of heating and time of permanence at the final temperature in the yield of solid products (coal) condensable and non-condensable volatiles, besides the characteristics of coal produced. These characteristics were: actual density, apparent density, porosity, superior calorific power, content of volatiles materials, ashes, fixed carbon and also granulometric reduction.

The pyrolisis has been made in electric mufle of laboratory, using the temperatures of $300,450,600,750$ and $900^{\circ} \mathrm{C}$, at the heating rate of 1,3 and $5^{\circ} \mathrm{C} / \mathrm{minute}$, and time of permanence at the final temperature of 30 and 90 minutes. 
By the results, it has been observed that among the factors tested in pyrolisis. of peat, the final temperature had the major effect at the variation of gravimetric yield of products and characteristics analysed on its coal. Generally, the peat classified at first above $10 \mathrm{~mm}$ has suffered a reduction on its granulometry, at levels of 40-45\% after the pyrolisis. As greater the final temperature of pyrolisis, the larger the yield of volatiles, actual density, apparent density, superior calorific power, content of ashes and content of fixed carbon, while the smaller the gravimetric yield and content of volatiles materials of peat coal. The porosity of peat coal was the parameter that was less influenced by the factors tested. The superior calorific power was positively correlated with the production of volatiles during hte pyrolisis, and with the content of fixed carbon of peat coal. The production of peat coal is viable with multiple possibilities of application, in face of the different characteristics obtained. 


\section{INTRODUÇÃO}

A partir da dēcada de setenta, o mundo viu-se diante de uma grande crise energética. De um lado, uma demanda crescente de energia provocada pelo desenvolvimento in dustrial; aumento populacional e elevação do nível de vida e, por outro lado, o consumo de energia centrado na utilização de produtos petrolíferos. O petróleo tornou-se substancialmente caro e oligopólico, ficando inümeros paises diante de um quadro energético instāvel.

Tal preocupação levou e ainda tem levado vários paises importadores de petróleo para a busca de novas fontes alternativas de energia, visando a atender $\circ$ desejo da menor dependência dos hidrocarbonetos e da necessidade geopolitica de ter as reservas de energia em seus. próprios 
territórios.

o Brasil é um dos maiores paises do mundo em área, com rica e abundante flora e imensas reservas hidrominerais. Isto confere ao país grande versatilidade para ajus tar o uso de diversas fontes alternativas, sobrèssaindo entre outras: biomassa, energia solar, energia hidrāulica, :energia eōlica, turfa, etc..

Particularmente a turfa tem despontado como promissora fonte alternativa de energia. Os estudos sobre sua possivel participação no leque de fontes novas e alterną tivas de energia vem crescendo gradativamente.

A turfa tem excelente distribuição geogräfica com ocorrência en todo territōrio nacional. o potencial bra sileiro em termos de reserva de turfa è estimado em mais de 500 milhões de toneladas equivalentes de petróleo que, compa rativamente, representa o dobro da nossa reserva em gās natu ral e aproximamente $70 \%$ da nossa reserva petrolifera.

Em que pese sua potencialidade, as reais condiçōes que envolvem o uso de turfa nacional como material energético, ainda são alvo de estudos iniciais no Brasil. No 
geral, as informações existentes são aquelas oriundas de outros países.

As razões que estimulam a utilização de turfa como energētico, segundo SUSCZYNSKI (1982) e JAKKO POYRY ENENHARIA (1983), basicamente, são: a) a turfa è um combustível fóssil doméstico de uso regional; b) è um combustivel possîvel de utilização em grande e pequena escala, gerando uma sērie de benefícios sociais; c) è um combustível seguro quanto a preservação de aspectos ambientais, pois seu teor de enxofre è baixo e suas cinzas podem ser empregadas no-meIhoramento de solos; d) apōs a extração de turfa, āreas ante riormente improdutivas podem ser convertidas para agricultura e reflorestamento; e) em região com reservas abundantes de material turfáceo é a fonte energética mais econômica; f) a turfa é disponivel universalmente; g) além de sua utilização em combustão direta, da turfa podem ser obtidos uma série de outros combustiveis sólidos, líquidos e gasosos.

A nação brasileira é a maior produtora e consumidora de carvão vegetal do mundo, mas cerca de $80 \%$ deste produto provém de madeira de mata nativa causando. grande pressão de desmate e destruição às nossas florestas. A repo sição florestal existente não é suficiente e ademais o custo de madeira de reflorestamento para produção de carvão é excessivamente alto. Daí, o carvão vegetal oriundo de flores- 
tas implantadas ser de três a quatro vezes mais caro que 0 proveniente de mata nativa. Veja o caso do Estado de Minas Gerais, que sendo o maior consumidor de carvão vegetal do Brasil, ilustra tal situação. Segundo a Associação Brasileî ra de Carvão Vegetal (1986), este Estado possui. uma reserva florestal correspondente a $1,245 \times 10^{6} \mathrm{~m}^{3}$ de lenha que deduzindo-se deste volume as reservas para fins legais e protecionistas e demanda para diversos usos, resta um potencial para produção de cerca de 400 milhões $\mathrm{m}^{3}$ de carvão vegetal, suficiente apenas para atender a demanda num periodo de apro ximadamente 15 anos, mantendo a atual proporção de mata nati va e de reflorestamento na obtenção deste insumo. Acrescenta-se ainda, o fato de pesquisadores e entidades do setor florestal preverem um escasseamento progressivo de madeira, além do fato desta ter outros usos e alguns deles mais nobres.

Um fato que merece mencionar é o carvão mineral que o Brasil possui em quantidade, mas com qualidade não adequada para uso siderürgico generalizado e com problemas de distribuição geogräfica, pois as reservas explorāveis encontram-se situadas na região sul. Esta realidade leva o país a importar cerca de $80 \%$ do carvão necessārio ao seu con sumo, principalmente na formação de coque mineral. 
Em função dos problemas existentes com a madeira e o carvão mineral, respectivamente matérias-primas para obtenção do carvão vegetal e coque mineral, acredita-se que a turfa deva ser estudada no sentido de se verificar a possibilidade do seu emprego como uma alternativa de insumo para os setores energētico e metalūrgico-siderūrgico brasileiros.

Um dos estudos básicos primeiros que se deva realizar sobre a turfa, visando-se a obtenção de carvão ou coque é o estudo laboratorial da sua pirólise. Esta é a proposta geral deste trabalho cujos objetivos especificos são:

a. caracterizar a turfa usada e determinar sua qualidade;

b. determinar os rendimentos do processo de pirólise da turfa em relação a produção de produtos sólidos, voláteis condenāveis e volāteis não-condensāveis;

c. alèm dos rendimentos, determinar as características dos produtos sólidos obtidos, com ènfase sobre as influèncias da temperatura final, taxa de aquecimento e tempo de permanência na temperatura final; 
2. REVISÃO DE ITTERATURA

\subsection{Caracteristica da turfa}

Segundo CENCIG et alii (1983), a turfa representa a primeira etapa da sērie dos combustiveis fósseis na escala metamörfica: turfa, linhito, carvão mineral, antracito, sendo teoricamente o grafite o produto final.

Pelos conceitos clāssicos energéticos, WILLIAMS BROTHERS ENGINEERING COMPANY (1979), PUNWANI (1980a), CONCEIÇÃO (1982) e MARTINO \& KURTH (1982), conceituam a turfa como sendo um combustível sólido fóssil de idade recente ou geologicamente jovem.

Alguns autores como LEPPA (1981), HINRICKSEN (1981) e SUSCZYNSKI (1982), incluem a turfa como sendo um 
perfeito composto de transição entre a biomassa e combustivel fóssil natural como o carvão mineral.

Para GOODWIN (1983), a turfa também pode ser aceita como um recurso da biomassa, ou seja uma vegetação energética derivada do sol e, as turfeiras consideradas com sitios de materiais orgânicos ou florestas energéticas antigas sepultadas e degradadas.

Segundo LARBALETRIER (s.d.), a turfa è uma ma téria esponjosa, marron ou preta, que resulta da decomposição lenta, operada em meio aquoso, de vegetais diversos e as pro priedades deste material variam muito com a natureza das plantas de origem e o grau mais ou menos avançado de decompo sição. Este mesmo autor afirma que a turfa é uma substância interessante, pois tem usos mültiplos e forma, por assim dizer, a transição natural entre a matéria viva e a matéria mi neral.

A composição química elementar da turfa é prō xima a da madeira. Segundo CHRISTIASSON (1953), PUNWANI \& RADER (1978), PUNWANI (1980a) e LEPPA (1981), a turfa apresenta uma composição química elementar média em torno de 55\% de carbono, 36\% de oxigênio, 6\% de hidrogênio, $2 \%$ de nitrogê nio e menos de $0,3 \%$ de enxofre. A madeira, segundo BRITO (1978), PETROFF \& DOAT (1978) e BRITO \& BARRICHELO (1982), contēm em média $51 \%$ de carbono, 42,5\% de oxigênio, 6,5\% de 
hidrogēnio e pequena fração de nitrogēnio e enxōfre.

As propriedades e carzateristicas entre turfas são muito variadas. Daĩ, hã vārias propostas de classificação de turfas. Há na literatura uma tendência de enquadrar as turfas baseando-se, principalmente, no grau de decom posição e na quantidade de fibras do material turfáceo. Assim, segundo COHEN (1983) as turfas são descritas como sendo fibrosa, hêmica e sáprica, cujas caracterizações são apresen tadas na Tabela 1 . Os percentuais de fibras nas turfas, de acordo com Severson et alii ${ }^{I}$, citados por LAMASTERS et alii (1983), são: mais de $70 \%$ nas fibrosas, de 70 a $40 \%$ nas hêmicas e menos de $40 \%$ nas sápricas.

Outro método de classificar turfa também de interesse exclusivamente energético, é o proposto pelo Depar tamento de Energia dos Estados Unidos da América. Este méto do, segundo PUNWAI (1980b) e KEYS (1983), reconhece duas classes: turfa combustivel - em condições seca, deve possuir poder calorifico minimo de $4400 \mathrm{Kcal} / \mathrm{kg}$, teor de cinzas não exceder a 25\%, ocorrer em depósito que em média atinja mais de 1,22 metros de profundidade e cuja área da turfeira deve situar entre 32 a 260 hectares; turfa não-combustivel - quan

1 SEVERSON, L.S.; MOOERS, H.D.; MALTERER, T.J. Inventory of of peat resorces; Koochiching Country, Minnesota. St. Paul, Department of Natural Resources, Division of Minerals, 1980 . 


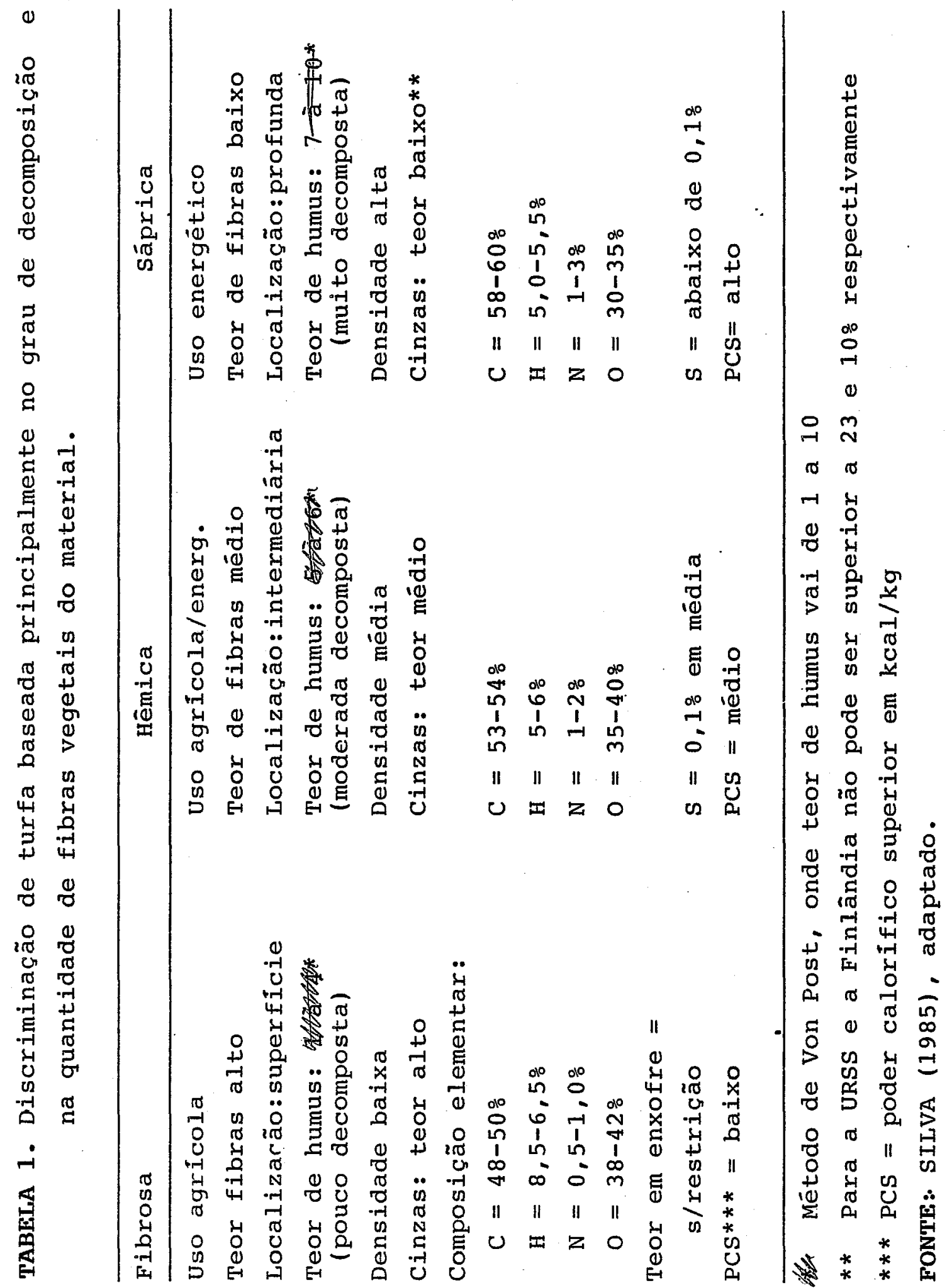


do suas caracteristicas não enquadram nas anteriores.

Para KEYS (1983), as turfas mais decompostas tendem a ter poder calorifico e densidade maiores em relação as turfas menos decompostas.

\subsection{Disponibilidade e formas de exploração}

As reservas de turfa ocorrem no mundo inteiro, porém segundo ANSON et alii (1981) e HINRICKSEN (1981), as maiores ocorrências de depósitos turfáceos são localizadas na faixa de florestas de coniferas da Finlāndia, Suécia, Estados Unidos e na Rūssia. Alguns países como Nova Zelāndia, Brasil, Argentina, Uruguais e alguns dos continente africano, segundo PUNWANI (1980a), apresentam depósitos de turfa substancialmente significativos e com boas perspectivas de viabị lidade energética.

Enfocando a reserva de turfa nacional, a maio ria dos autores concorda que ela é suficientemente significa tiva e caracteriza-se pela excelente distribuição geográfica. Ela é estimada segundo MATTAR \& DELAZARO (1980) e RODRI GUES (1983), em 25 milhões de metros cúbicos "in situ" enquanto SUSZYNSKI (1982) e KUMOTO et alii (1985) citando a Companhia de Pesquisas de Recursos Minerais e o Instituto de Pesquisas Tecnológicas de São Paulo, apresentam uma reserva 
turfácea nacional de 20,5 milhões de metros cúbicos "in situ", que em termos energéticos equivale a aproximadamente 500 mihões de toneladas equivalentes de petróleo.

Considerando os recursos e reservas energèticas globais brasileiras, segundo BRASIL-MINISTERIO DAS MINAS E ENERGIAS-BALANÇO ENERGETICO NACIONAL (1986), estes somavam ao final de 1985 9,6 bilhões de toneladas equivalentes de pe tróleo, assim distribuidas: carvão mineral 62\%, energia nuclear $22 \%$, óleo de xisto $7 \%$, energia hidráulica 3\%, petróleo 3\%, turfa 2\% e gás natural 1\%. Comparativamente, significa que em termos energéticos a reserva turfácea nacional equiva le a aproximadamente $200 \%$ da reserva de gás natural e respec tivamente $67 \%$ das reservas de petróleo e de energia hidráuli ca) Na Tabela 2, tem-se informações sobre os potenciais de determinadas turfeiras identificadas como energéticas, em al guns estados brasileiros. Todavia, nestes e nos demais esta dos do Brasil há turfeiras identificadas, porém não quantifí cadas energeticamente.

A tecnologia de exploração e processamento da turfa, é bem concebida com a redução do teor de umidade do estado natural, que é de aproximadamente $90 \%$, para valores menores que 50\% (em.geral entre 15-20\%), através de métodos de secagem ao ar ou artificialmente na sua própria área de depósito (FARNHAM, 1974 e PUNWANI \& RADER, 1978). Baseando- 
TABELA 2. Recursos identificados de determinadas turfeiras em alguns estados brasileiros.

\begin{tabular}{lccc}
\hline Estado & $\begin{array}{c}\text { Areas das } \\
\text { turfeiras } \\
(\text { ha) }\end{array}$ & $\begin{array}{c}\text { Reserva de } \\
\text { turfa em } \\
\text { base seca. } \\
(106 \text { t) }\end{array}$ & $\begin{array}{c}\text { Equiválente } \\
\text { energético } \\
(106 \text { tep) }\end{array}$ \\
\hline Bahia & 38.430 & 66,80 & 161,374 \\
Espirito Santo & 15.525 & 26,26 & 83,636 \\
Minas Gerais & 7.550 & 27,13 & 60,117 \\
Maranhão & 7.568 & 16,52 & 54,320 \\
Rio Grande do Norte & 7.000 & 17,02 & 47,273 \\
São Paulo & 4.857 & 14,96 & 32,883 \\
Rio Grande do Sul & 4.780 & 12,00 & 34,893 \\
Alagoas & 3.214 & 7,23 & 18,842 \\
Rio de Janeiro & 2.600 & 4,90 & 17,458 \\
Paraiba & 2.863 & 4,88 & 11,294 \\
Sergipe & 445 & 0,78 & 2,722 \\
\hline Total & 96.572 & 204,92 & 541,026 \\
\hline
\end{tabular}

FONTE: GALVÃ ${ }^{1}(1986)$, adaptado.

1 GALVÃO, L.A.G. (Companhia de Pesquisas de Recursos Minerais, Brasilia). Comunicação Pessoal; 1986. 
-se nisso, KUMOTO et alii (1985) e OKAGAWA (1985), citam a existēncia de duas técnicas distintas para extração de turfa. Pode-se, dessa forma, obter a turfa escarificada ou fre sada (equivale a turfa a granel) e a turfa extrudada (em for ma de tarngos). Estas são as formas de obtencão com uso mais provável no Brasil, pois requerem equipamentos simples e também dada as nossas condições climáticas de grande perío do de insolação, umidade relativa do ar pouco limitante e pe riodo de estiagem suficiente para propiciar a extração e secagem da turfa.

\subsection{Comportamento da turfa frente ao processo de pirólise}

\subsubsection{Rendimento dos produtos}

A pirólise visando a obtenção de carvão ou carbonização, è o método mais antigo de conversão de materiais como carvão mineral, turfa e madeira em produtos combustiveis e insumos diversos. A.temperatura final de degradação e a taxa de aquecimento, assim como o tempo de permanēncia na temperatura máxima final são fatores de maior importância no processo, além da própria matéria prima que está sendo usada. Estes fatores apresentam uma grande margem de variação, o que permite obter resultados di 
versos em termos de rendimento e caracteristicas de produtos e subprodutos para cada situação empregada durante o processo de pirólise.

Segundo BERTHELOT \& KLINDS (1943), dadas as condições do material de origem e sua composição atual, exis te uma forte analogia entre a pirólise de turfa e de madeira, desde condições de temperatura, atē a natureza dos produtos obtidos.

WENZL (1970), GOMES \& OLIVEIRA (1980) e OLIVEIRA et alii (1982a) afirmam que a temperatura de aquecimen to é uma das variáveis mais importante e controladora dos produtos obtidos da carbonização de madeira. A sua influencia nos rendimentos de carvão, liquidos e gases não con densáveis são bem conhecidas. Segundo Dupont ${ }^{1}$, citado por RAMALHO (1943), HARRIS (1978), OLIVEIRA et alii (1982c), ALMEIDA (1983) e FARIA (1984), quanto maior a temperatura de aquecimento, maior será o grau de destilação do material,com - consequente aumento na quantidade de líquido e gās não con densāvel; em contrapartida, ocorre uma redução no rendimento do produto sólido. OLIVEIRA et alii (1982b), estudando o com portamento da madeira de Eucalyptus grandis, com idade de 6, 8 e 10 anos, à temperatura de 300,500 e $700^{\circ} \mathrm{C}$, verificaram

$\bar{I}$ DUPONT, G. Distillation du bois. Gauthier, Villars et Cie., Paris, 1924. 
que as maiores taxas de redução no rendimento gravimétrico do carvão ocorre a temperatura mais baixas, havendo uma tendência de estabilização com a elevação da mesma. Segundo es tes autores, o aumento da temperatura facilita a dissociação do carvão com a liberação dos gases, podendo mésmo gaseificar parte de sua estrutura sólida, acarretando um decréscimo no rendimento.

\section{PETROFF \& DOAT (1978) e OLIVEIRA et alii} (1982d) mostram que o comportamento térmico da matéria prima reflete a soma das respostas térmicas de seus principais com ponentes: a hemicelulose é o componente menos estável e decompõe-se entre 225 e $325^{\circ} \mathrm{C}$; a celulose se degrada em temperaturas mais altas, entre 325 e $375^{\circ} \mathrm{C}$ e produz inúmeros compostos voláteis; a lignina é o componente mais estável e se. decompõe građualmente, entre 250 e $500^{\circ} \mathrm{C}$ e contribui, princí palmente para a formação do resíduo carbonífero.

BRITO \& BARRICHELO (1977), estudando a carbonização dos componentes individuais da madeira verificaram que a lignina apresentou rendimento mais elevado em carvão, em função da mesma ser um componente de estrutura complexa e muito resistente a ̀̀ pirólise. Semelhantemente, PETROFF \& DOAT (1978) encontraram uma correlação bastante significativa entre rendimento gravimétrico do carvão e o teor de lig nina de diversas madeiras tropicais. Também, SILVA 
encontrou nos endocarpos de palmāceas (babaçu e macaúba) con teúdo em lignina maior que na madeira de eucalipto. o mesmo autor, carbonizando estes materiais, observou que os endocar pos de palmáceas apresentaram maiores rendimentos em carvão e menores rendimentos em voláteis, quando comparados com a madeira de eucalipto.

Waksman \& Starkley ${ }^{1}$ citados por KIEHL (1985), afirmam que devido à ausēncia de quantidade suficiente de oxigênio gasoso na atmosfera (oxigênio não combinado), em consequência da saturação do material vegetal pela água onde se formam as turfeiras, não se dã a oxidação completa da matēria orgānica. A decomposição é realizada por bactérias e fungos anaeróbicos; em tais condições, constituintes como as graxas e ligrinas são pouco decompostos, enquanto outros como celulose e hemicelulose são atacados lentamente.

Assim, em função da lignina o rendimento gravimétrico em carvão de turfa deve ser sensivelmente maior em relação ao carvão vegetal obtido da madeira.

LARBALETRIER (s.d.) cita a obtenção de rendimento gravimétrico de carvão de turfa variando de 34 a $54 \%$.

I WAKSMAN S.A. \& STARKEY, C. The soil and microbe. N. York, John Wiley, 1949. 
CHRISTIASSON (1953), TRONT (1958) e Korchunov ${ }^{1}$ citado por FUCHSMAN (1980), submetendo a turfa à temperatura final de $500^{\circ} \mathrm{C}$, obtiveram rendimento em carvão sensivelmente maior que o observado para carbonização de madeira nesta mesma tem peratura. Por sua vez, SILVA \& BRITO (1987) em. outro estudo sobre termodegradação de turfas de três origens distintas e madeira de Eucalyptus grandis à temperatura final de 400$-500^{\circ} \mathrm{C}$ e taxa de aquecimento de $50^{\circ} \mathrm{C}$ a cada 30 minutos, obti veram rendimento gravimétrico em carvão em torno de 50\%, mes mo descontando-se a influência do teor de cinzas como material inerte, valor este bastante superior que o obtido para a madeira. Com relação ao rendimento em volāteis condensáveis e não condensáveis, tais autores encontraram comportamento inverso ao rendimento de carvão. Segundo eles, a madeira apresenta na sua composição química original teor de matérias voláteis superior ao de turfa e que esta seria a ra zão para explicar o menor rendimento em voláteis por parte da turfa.

$$
\text { Tratando-se da pirólise de turfa, }
$$
FUCHSMAN (1980) afirma que a baixas temperaturas, especialmente a $200-250^{\circ} \mathrm{C}$, hā rompimento de grupos carboxilicos, hemicelulose e ácidos húmicos e, no geral, em torno de 300-

1 KORCHUNOV, V.S. Increasing of solid product yield in milled beat pyrolise. International Congress, 4., Otaniemi, Finland, 1972. Proceedings, 1972. p. 165-75. 
$-312^{\circ} \mathrm{C}$ ocorre quebra na estrutura de carbohidratos, com produção de gases contendo principalmente água e dióxido de carbono, pequena quantidade de ácido acético e amônia e monó xido de carbono. o mesmo autor afirma que à temperatura superior a $300^{\circ} \mathrm{C}$ há ruptura de ligação carbono-carbono que for mam os compostos inicialmente presentes na turfa, sendo a estrutura aromática dos ácidos húmicos rompidas, bem como há desarranjo na estrutura da lignina. zHUKOV et alii explicam que a termodegradação da turfa inicia-se em 150$-200^{\circ} \mathrm{C}$ e a principal decomposição encontra-se nas temperaturas situadas entre 300 e $500^{\circ} \mathrm{C}$. Para BEL'KEVICH et alii (1971), a intensidade de decompoșição da turfa aumenta, no geral, com aumento na temperatura, sendo que de 150 a $250^{\circ} \mathrm{C}$, com cinco horas de processo, o grau de degradação térmica vai de 2 a $25 \%$

Para baixo grau de aquecimento, a produção de substâncias voláteis depende da qualidade básica da turfa e temperatura. final de pirólise. CHUKANOV et alii (1962) diz que o rendimento em produtos voláteis aumenta gra dualmente com aumento na temperatura a partir de. $400-450^{\circ} \mathrm{C}$, mas após $600^{\circ} \mathrm{C}$, torna-se insignificante a variação no rendimento final deste produto. Para SHAPATINA et alii (1960), logo após a temperatura de carbonização atingir $500^{\circ} \mathrm{C}$, a quantidade de produtos voláteis formados varia muito pouco. Segundo FUCHSMAN (1980), as reações associadas com a perda 
de peso no material termodegradado, predominantemente, completam-se até $500^{\circ} \mathrm{C}$ e que, a altas temperaturas pequenas quantidades de produtos gasosos são produzidas. 0 mesmo autor verifica que a degradação tende a completar-se em torno de 600 a $700^{\circ} \mathrm{C}$, mas entre as temperaturas de 700 e $900^{\circ} \mathrm{C}$ ain da pode haver eliminação de produtos voláteis, possivelmente predominando o hidrogênio.

O residuo sólido da turfa, obtido a $300^{\circ} \mathrm{C}$, se gundo FUCHSMAN (1980) contém considerável quantidade de oxigênio e hidrogēnio, os quais podem ser removidos a medida que aumenta a temperatura de degradação. Assim, as características de ambos os gases - condensáveis e não condensáveis, sofrem variações nos produtos que os compõem, à medida que se eleva a temperatura de degradação. Por exemplo, o mesmo au tor, verifica que até aproximadamente $550^{\circ} \mathrm{C}$ há predominância de dióxido de carbono em relação ao monóxido de carbono na composição de voláteis voläteis não-condensāveis, mas à proporção que a temperatura de aquecimentovai sendo elevada deste patamar de $550^{\circ} \mathrm{C}$, há uma situação inversa, destacando-se o monóxido de carbono sobre o dióxido de carbono na composięão dos mesmos voláteis. Ainda o mesmo autor afirma que os voláteis condensāveis, basicamente, são compostos de āgua, alguns óleos e material semelhante ao pixe e como citado anteriormen te, podem sofrer alterações em função da temperatura final em que são obtidos. 
Com relação à redução volumētrica, Ekmañ ${ }^{1}, c \underline{\underline{i}}$ tado por FUCHSMAN. (1980), afirma que a turfa ao ser degradada termicamente perde de 40-50\% em volume por particula indi vidual. A redução volumētrica, segundo o mesmo autor, inicia-se entre $250-300^{\circ} \mathrm{C}$ e atinge um gradiente mäximo a:400$-450^{\circ} \mathrm{C}$ e após $500^{\circ} \mathrm{C}$ há pouca contração adicional.

Além da temperatura final, outro fator que merece enfoque especial: no processo pirólise. é a taxa ou velocidade de aquecimento, o que significa processo com maior ou menor duração. No geral, tratando-se de processo lento, à taxa de aquecimento na pirólise varia de 0,5 a $10^{\circ} \mathrm{C} /$ minuto até atingir a temperatura final. OLIVEIRA et alii (1982d), COUTINHO (1984) e VALENTE et alii (1985) carbo nizando madeira em retorta elétrica de laboratório à tempe ratura final de $500^{\circ} \mathrm{C}$, utilizaram $1,5-2,0^{\circ} \mathrm{C} /$ minuto como taxa média de aquecimento. SILVA (1986) carbonizando madeira de eucalipto e endocarpos de palmáceas nas temperaturas finais de 300,500 e $700^{\circ} \mathrm{C}$, partindo de uma temperatura inicial de $100^{\circ} \mathrm{C}$, utilizou-se urna taxa média de aquecimento subindo $50^{\circ} \mathrm{C}$ a cada 30 minutos. Em, pirólise de turfa, - Korchunov ${ }^{2}$ citado por FUCHSMAN (1980) afirma: a) o rendimento e a quali

1 EKMAN, E. Bull. Int. Peat. Soc. 7 : 39-49, 1975.

2 KORCHUNOV, V.S. Increasing of solid product yield in milled peat pyrolise. International Congress, 4., Otaniemi, Finland, 1972. Proceedings, 1972, p. 165-75. 
dade dos produtos a baixa temperatura são influenciados pela taxa de aquecimento, pois esta determina a razão em que os fragmentos de baixo peso molecular reagem e recombinam para formar compostos não voláteis de alto peso molecular; b) em taxa de aquecimento maiores, os fragmentos de turfa tendem a volatilizar mais rapidamente e consequentemente formam menor quantidade de substâncias de alto peso molecular; c) provavelmente, as substâncias de alto peso molecular são mais estāveis e sofrem pouca volatilização e, com isso, o rendimento em carvão de turfa decresce à medida que aumenta a taxa de aquecimento.

\subsubsection{Caracteristica do carvão}

Presentemente, vamos designar o termo carvão de turfa para o produto sólido obtido da sua pirólise.

Dependendo da temperatura final de pirólise e de algumas caracteristicas do produto residual, há uma tendência de chamar o carvão de turfa de semi-coque ou coque. Para FUCHSMAN (1980), semi-coque caracterizaria o produto sólido obtido em torno de $450^{\circ} \mathrm{C}$, enquanto coque seria referente ao produto conseguido, via de regra, à maiores temperaturas. Já, segundo LARBALETRIER (s.a.), coque e carvão são sinônimos quando se trata de pirólise de turfa. 
No que tange às propriedades e caracteristi cas do carvão, elas estão intimamente ligadas aos fatores do processo de produção que the deu origem. Assim, MENDES et alii (1982) afirmam que estes fatores e o seu controle são de grande utilidade na fabricaçaõ e escolha do čarvão para ser usado para diferentes fins.

No caso da densidade, sua determinação è imtportante na caracterização do carvão, pois outras propriedades estão intimamente a ela relacionadas como por exemplo re sistēncia físico-mecānica, porosidade e quantidade de energia por unidade de volume.

Usualmente a densidade de materiais como car vão é determinada com esse produto submetido a duas condições distintas: a) carvão reduzido a pó, onde se pretende me dir a densidade da "substância carvão" e que fornece a chamada densidade verdadeira; $b$. carvão em pedaços, incluindo neste caso, sua porosidade e, que resulta na denominada densidade aparente.

MENDES et alii (1982) verificaram-que a densi dade e porosidade do carvão são fortemente influenciadas pela densidade do material de origem, pela temperatura final e taxa de aquecimento.

A maioria dos autores concorda que a densidade do carvão está intimamente ligada à densidade da matéria 
prima que the deu origem. Estudando a pirólise de madeira, PETROFF \& DOAT (1978), OLIVEIRA \& ALMEIDA (1980) e BRITO \& BARRICHELO (1982) encontraram correlação altamente significativa entre a densidade da matéria prima e a densida de do carvão obtido.

SILVA \& BRITO (1987), verificaram que o carvão de turfa é mais denso e menos poroso em relação ao carvão de madeira de Eucalyptus grandis e a razão para tal é a turfa originalmente ter apresentado maior densidade em relação a madeira.

A taxa de aquecimento pode influenciar a densidade do carvão. EARL (1975) e MENDES et alii (1982) afirmam que o carvão oriundo de uma pirólise lenta tende a ser mais denso que o obtido no processo mais rápido. Estes autores comentam que a pirólise rāpida de madeira não produz carvão com boas propriedades físicas, notadamente para fins siderúrgicos.

Quanto à temperatura final de degradação, esta tem efeito peculiar na densidade do carvão, não havendo ainda uma disponibilidade de informacōes totalmente conclusi vas a respeito. Estudando a pirólise da madeira de Prunus serotina em várias temperaturas, Blankenhorn ${ }^{1}$ et alii of blackcherry carbonized in an inert atmosphere. Wood Science. Madison, $11(11)=23-9$, July, 1978 . 
citados por OLIVEIRA et alii (1982c), verificaram uma tendēn cia da densidade aparente decrescer até por volta de $600^{\circ} \mathrm{C}$ e então aumentar até $900^{\circ} \mathrm{C}$, ençuanto a densidade verdadeira aumentou de 300 para $500^{\circ} \mathrm{C}$ e permaneceu mais ou menos constante entṛe 500 e $900^{\circ} \mathrm{C}$. Já WENZL (1970) revela que a densi dade verdadeira deve aumentar e a densidade aparente decrescer com o aumento na temperatura final de degradação. Segun do OIIVEIRA et alii (1982d), quanto maior for a temperatura de degradação, maior será o volume de poros do carvão, em de corrēncia da expulsão dos gases, provocando uma diminuição da densidade aparente. Os mesmos autores mencionam que a densidade verdadeira aumenta sistematicamente com aumento na temperatura, pois acontecem rearranjos nas cadeias de carbono à medida que há elevação da temperatura, ocorrendo diminuição na distância entre átomos de carbono.

A porosidade está ligada à densidade aparente e indica o conteúdo de vazios no produto carbonoso resultante da termodegradação. Conforme jã discutido anteriormente, - aumento na temperatura provoca expulsão dos gases, deixando vazios ou poros no interior do carvão.

Conforme afirma TROSSERO (1981) o teor de carbono fixo e o poder calorífico do carvão está em função direta da temperatura final de degradação. Todavia, MEN 
DES et alii (1982) trabalhando com termodegradação de madeiras às temperaturas de 300,500 e $700^{\circ} \mathrm{C}$, verificaram que 0 poder calorifico do carvão obtido foi maior à temperatura de $500^{\circ} \mathrm{C}$. Segundo os mesmos autores, o aumento do poder calori fico do cárvão produzido a $500^{\circ} \mathrm{C}$ é explicado em função da sua composição química elementar, pois observa-se que o teor de oxigênio cai sensivelmente quando se passa de 300 para $500^{\circ} \mathrm{C}$. De maneira mais ou menos semelhante, COUTINHO (1984) observou que o poder calorifico aumenta apenas com a elevação da temperatura na faixa de 400 a $600^{\circ} \mathrm{C}$, mantendo-se cons tante a temperaturas superiores.

- Num trabalho relativo a temperatura final de degradação de turfa e o rendimento do resíduo sólido, Keppeler e Holfmann ${ }^{1}$ citados por FUCHSMAN (1980) utilizaram as temperaturas finais de 450 a $550^{\circ} \mathrm{C}$ e turfa com teor de umida de de 7,6\%. Eles obtiveram 57,10\% de produto sólido contendo $28,15 \%$ de voláteis e poder calorifico de $6932 \mathrm{kcal} / \mathrm{kg}$ à $450^{\circ} \mathrm{C}$ e a $550^{\circ} \mathrm{C}$; o rendimento foi de $43,50 \%$ tendo o conteúdo de vo láteis de $17,50 \%$ e o poder calorifico de $7191 \mathrm{kcal} / \mathrm{kg}$. Assim, depreende-se um comportamento similar da turfa em relação à madeira frente o processo de termodegradação, quando se trata de rendimento, composição quimica e poder calorifico do produto carbonoso.

1 KEPPELER, G. \& HOLFFMANN, H. Brennstoff Chemie, 13:401-6, 1932 . 
Vários autores, WENZL (1970), EARL (1975) e FARIA (1984), JUVILLAR (1980), MENDES et alii (1982), OLIVEI RA et alii (1982b) e OLIVEIRA et alii (1982d), trabalhando com diversas madeiras, mostram que há aumento do teor de car bono fixo'à međida que aumenta a temperatura dè degradação . Segundo estes autores, o aumento do teor de carbono ocorre devido à liberação de compostos voláteis, condensáveis e não condensáveis, durante a termodegradação, formados principalmente por monóxidos de carbono, dióxido de carbono e hidrocarbonetos leves. Assim, o teor de carbono fixo no produto residual tende a aumentar, à medida que tais compostos são eliminados. Entretanto, para CouTINHO (1984) o teor de carbono fixo aumenta de forma acentuada com o aumento da temperatura na faixa de 400 a $700^{\circ} \mathrm{C}$ e se mantém constante em temperaturas de degradação superiores.

CHUKANOV et alii (1962), WENZL (1970), EARL (1975), MENDES et alii (1982), OLIVEIRA et alii (1982d) e AL MEIDA (1983), afirmam que a elevação de temperatura provoca expansão dos gases, expulsando-os do interior do carvão, o que vem determinar um menor teor de voláteis no produto final. A maioria destes autores observa que há uma correlação inversa entre a temperatura final do processo e o teor de ma térias voláteis do produto final.

Na literatura, não encontrou-se registro refe rente aos efeitos das condições de termodegradação de turfa 
no teor de cinzas. Entretanto, na termodegradação da madeira, o teor de cinzas do carvão é motivo de controvérsia. Es tudando a composição química do carvão de espécie florestal nativa, FARIA (1984) verificou que o teor de cinzas aumentou com a elevação da temperatura final. Em contra partida, HAR RIS (1980) afirma que a temperatura final de degradação não tem influēncia alguma sobre o conteúdo de cinzas. Para estas divergências encontradas, OLIVEIRA et alii (1982a) afirmam que elas podem ser acreditadas às caracteristicas de cada matéria prima utilizada na termodegradação. FUCHSMAN (1980) menciona que o teor de cinzas no produto residual vai depender do teor originalmente na turfa e das condições empregadas no processo. 


\section{METODOLOGIA}

O presente trabalho foi desenvolvido no setor de Química, Celulose e Energia do Departamento de Ciências Florestais, pertencente a Escola Superior de Agricultura "Luiz de Queiroz", da Universidade de são Paulo.

Foi utilizada turfa: procedente da Fazenda Vitória, situada no município de Araranguá, sul do Estado de Santa Catarina. A turfeira pertence a empresa COMINAS - Mi neradora Conventos S.A. do grupo CRECISA - Cerâmica Criciuma S.A.. As amostras de turfas foram retiradas de 6 pontos equidistantemente distribuidos à distāncias médias de $700 \mathrm{~m}$ em uma área piloto de 60 hectares, inserida numa turfeira de aproximadamente 2.000 hectares e com profundidade média de 2 a 2,5 metros. Sobre a turfeira predominava vegetação ras- 
teira, especialmente gramineas, havendo tambēm pequena faixa central com cobertura florestal. Escolheu-se esta origem de turfa por haver informações prévias quanto ao seu teor de enxofre que é relativamente baixo, grau de decomposição bastante avançado, facilidade de obtenção e traḅalhos pionei ros da empresa na área. Estas condições são importantes para o fim proposto no trabalho, principalmente quanto as propriedades e características dos produtos obtidos no processo de pirölise.

A turfa na forma a granel com $70 \%$ do seu volu me situada entre 10 e $30 \mathrm{~mm}$ foi coletada individualmente em cada ponto através do trado manual num perfil de 0,5 a 2,5 metros, a contar da superfície da turieira. As amostras coletadas foram misturadas perfazendo uma amostra final com vo Iume equivalente a 200 litros.

\subsection{Preparo e caracterização da turfa}

A turfa na forma a granel foi inicialmente se ca ao ar livre, homogeneizada e posteriormente seica em estuda a $\pm 105^{\circ} \mathrm{C}$. Portanto, o material foi utilizado absoluta nente isento de umidade. 
A caracterização da turfa foi efetuada através da determinação dos teores de matéria voláteis, de cinzas e de carbono fixo, densidade, porosidade, poder calorifi co superior, cujos métodos de determinação foram os mesmos empregados na análise do carvão. Ainda foi determinado o teor de carbono orgânico total da turfa utilizando-se o seguinte procedimento: amostra absolutamente seca com dimensões inferiores a 100 mesh, de peso conhecido, foi incinerada a $1.100^{\circ} \mathrm{C}$ e $\circ$ gás produzido $\left(\mathrm{CO}_{2}\right)$ foi analisado através do aparelho Carmograph 12A. O resultado foi expresso diretamente em porcentagem de carbono. As análises do teor de car bono orgânico foi realizaḍa no Departamento de Solos do Centro de Energia Nuclear na Agricultura.

\subsection{Pirólise das amostras}

Para cada ensaio utilizaram-se $400 \mathrm{~g}$ de material. Os ensaios foram realizados em retortas (muflas) elétricas devidamente equipadas para proceder a coleta das frações sólidas e líquida do processo, cujas temperaturas foram controladas por pirōmetros previamente calibrados. Uma representação esquemática do equipamento utilizado na pirólise da turfa è mostrada na Figura 1 . 


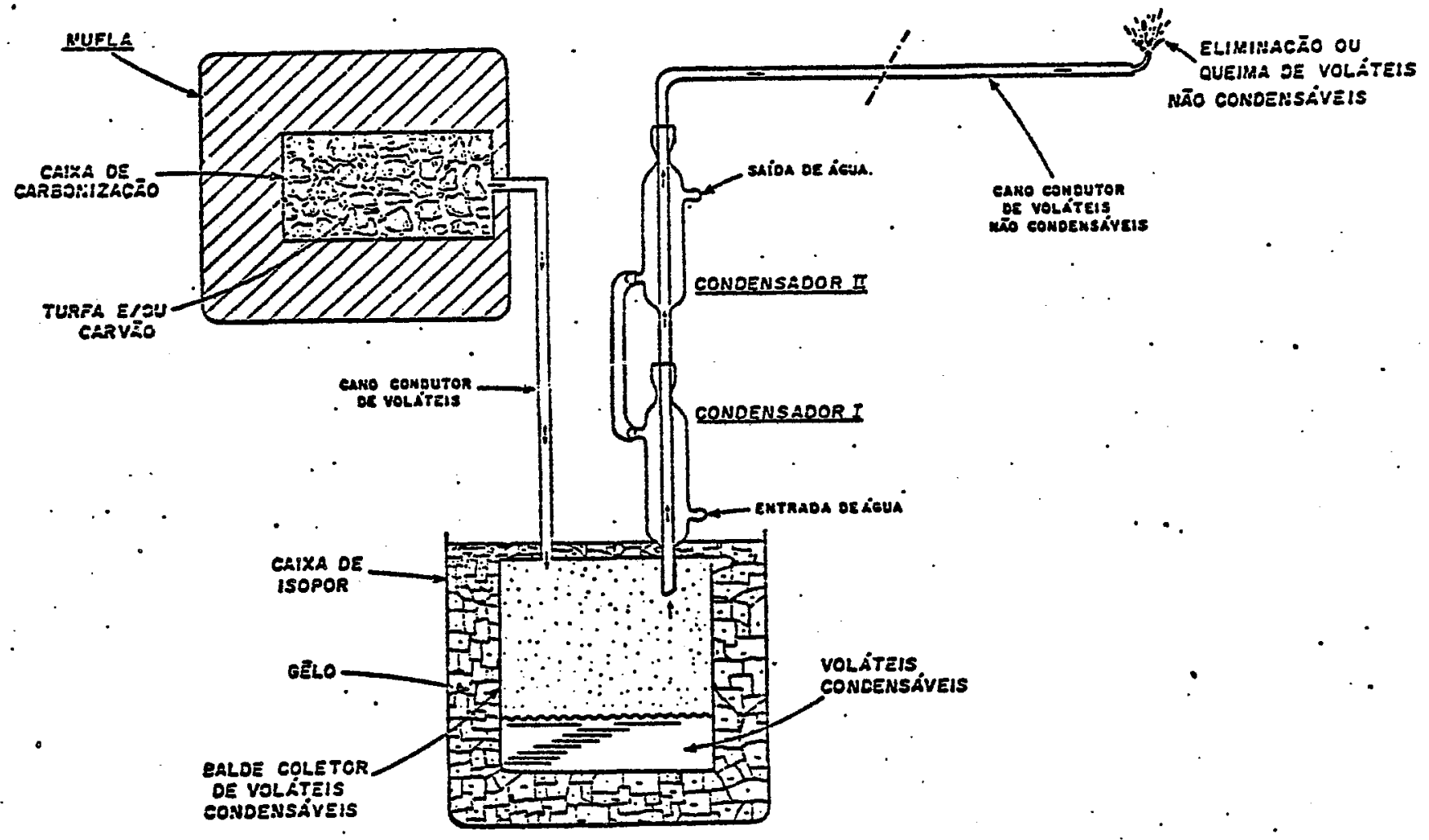

FIGURA 1. Representação esquemática do equipamento usado na termodegradação da turfa. 
Do volume inicial de 200 litros foram obtidas ao acaso, subamostras individuais de turfa que foram submeti das ao aquecimento, às temperaturas finais de $300,450,600$, 750 e $900^{\circ} \mathrm{C}$, a partir de uma temperatura inicial de $100^{\circ} \mathrm{C}$. As taxas médias de aquecimento na pirólise foram de 1,3 e $5^{\circ} \mathrm{C}$ por minuto, que caracterizam trēs taxas bem distintas e assemelham-se àquelas já usadas para madeiras e mes mo para turfas em trabalhos a niveis laboratoriais, conforme já citado anteriormente. Foram testados, também, dois tempos de permanência às temperaturas finais do processo, ou se ja de 30 e de 90 minutos. Para cada tratamento houve 2 (duas) repetições, perfazendo assim, um total de 60 ensaios.

Após cada ensaio, o aparelho foi resfriado até aproximadamenté $50^{\circ} \mathrm{C}$, procedendo-se, então, a retirada e pesagem dos produtos sólidos (carvão) e voláteis condensáveis. Os voláteis não condensāveis foram eliminados durante - processo.

3.3. Avaliação do rendimento e taxa de redução granulométrica da turfa na pirólise

Foram avaliados para cada pirólise os rendimentos gravimétricos percentuais de carvão, voláteis condensāveis com base no peso seco da turfa submetida a 
ação da: pirólise. O cálculo foi feito para cada repe tição utilizanōo a seguinte equação:

$$
R=\frac{P P}{P M S} \times 100 \ldots \ldots \ldots \ldots \text { (equação } 1 \text { ) }
$$

onde,

$\mathrm{R}$ = rendimento gravimétrico do produto sólido (carvão) ou volātil condensável $(\%)$;

PP = peso do produto sólido (carvão) seco ou do volátil condensável $(\mathrm{g})$;

PMS = peso da matéria seca $(g)$.

o rendimento em voláteis não condensáveis, foi obtido pela diferença dos rendimentos gravimétricos dos produtos sólidos e voláteis condensáveis, de um total de $100 \%$.

Tanto nà turfa original, como no seu carvão utilizando-se uma peneira de $10 \mathrm{~mm}$ de abertura, determinou-se a fração que ficou retira na mesma, utilizando-se a seguinte equação:

$$
Q=\frac{\mathrm{PFR}}{\mathrm{PTC}} \times 100 \ldots \ldots \ldots \ldots \ldots \text { (equação }
$$

onde,

Q = quantidade de turfa ou de carvão de turfa suncrior a $10 \mathrm{~mm} \mathrm{( \% );}$ 
PFR = peso da fração retida na peneira de $10 \mathrm{~mm}$ de abertura $(g)$;

PTC = peso do materiá (turfa ou carvão de turfa) usado na determinação $(g)$.

- Para determinar a taxa de reduçãó granulométrica ocorrida na termodegradação da turfa, aplicou-se os vạ lores obtiāos na equação 2 a seguir:

$$
R G=\frac{Q T-Q C}{Q T} \times 100
$$

onde,

$\mathrm{RG}=$ taxa de redução granụlométrica (\%);

$Q T=$ quantidade de turfa superior a $10 . \mathrm{mm}$ (\%).

$\mathrm{QC}=$ quantidade de carvão de turfa superior a $10 \mathrm{~mm}(\%)$.

\subsection{Anālises do carvão de turfa}

a. densidade verdadeira - obtida utilizando o método do picnômetro, citado por OLIVEIRA et alii (1982b), e expressa em $\mathrm{g} / \mathrm{cm}^{3}$.

b. densidade aparente - obtida empregando-se o método da balança hidrostática, segundo a mesma usualmente empregada para madeiras propostas pela Associação Brasileira de Celulose e Papel (M 14/74) expressa em $\mathrm{kg} / \mathrm{m}^{3}$; 
c. porosidade - foi estimada a partir da densidade aparente e da densidade verdadeira do carvão. A equação empregada foi:

Posidade $(\%)=\left(1-\frac{\text { densidade aparente })}{\text { densidade verdadeira }} \times 100 \ldots\right.$ (equação 4 )

d. poder calorifico superior - foi determinado pelo método da bomba calorimétrica, seguindo a norma NBR 8633 da ABNT - Associação Brasileira de Normas Técnicas;

e. análise imediata - foram obtidos os teores de matérias vo láteis, de cinzas e de carbono fixo através da norma NBR 8112 da ABNT.

3.5. Delineamento estatístico

Para análise estatistica dos resultados da termodegradação da turfa, utilizou-se o delineamento inteira mente casualizado com tratamentos fatoriais tendo duas repe tições por tratamento. Utilizaram-se 30 tratamentos discri minados nos fatores: 5 temperaturas finais, 3 taxas de aque cimento e 2 tempos de permanência às temperaturas finais. A Tabela 3 apresenta o esquema de análise de variância emprega do neste estudo. 
TABELA 3. Esquema de análise de variância empregado nos parā metros determinados.

Causa da variação

Grau de liberdade

Temperatura final (A)

4

Taxa de aquecimento (B)

2

Tempo de permanência (C)

Interação A x B

Interação $\mathrm{A} \times \mathrm{C}$

Interação B x C

Interação A X B X C

8

(Tratamentos)

Residuo

Após a análise de variância, procedeu-se o teste de comparação de médias por fatores e também para as interações ocorridas entre eles, utilizando o teste de WaIler-Duncan. O nivel de significância deste teste segue o mesmo dado por $F$ na análise de variāncia. 
De forma complementar e para auxiliar a discussão dos dados foram determinadas correlações estatisticas entre alguns parâmetros analisados no carvão de turfa utilizando -se de todos os resultados individuais de cada tratamento. No caso foram analisados os coeficientes de correlação.

Para os dados em porcentagem, cujo coeficiende variação foi alto (acima de 20\%), procedeu-se a transformação dos dados para arc seno $\sqrt{\mathrm{x} / 100}$. 


\section{RESULTADOS E DISCUSSÃO}

\subsection{Caracterização da turfa}

As características da turfa são apresentadas na Tabela 4.

Verifica-se que este material enquadra-se como turfa energētica, conforme proposta de classificação do Departamento de Energia dos Estados Unidos apresentada por PUNWANI (1980b) e KEYS (1983) jā citada na revisão de litera tura.

Com base em COHEN (1983) e SILVA (1985) deduz-se que a turfa usada pode tambēm ser classificada entre hêmica e sāirica, portanto com maior grau de decomposição e menor teor de fibras que tambēm implica em material destinado para fins energéticos. 
TABELA 4. Caracterização da turfa.

\begin{tabular}{|c|c|c|c|}
\hline Parāmetros & $\begin{array}{l}\text { Número } \\
\text { de } \\
\text { repet. }\end{array}$ & Médias & $\begin{array}{c}\text { Coeficiente } \\
\text { de variação } \\
\left(\frac{0}{0}\right)\end{array}$ \\
\hline Densidade verdadeira $\left(\mathrm{g} / \mathrm{cm}^{3}\right)$ & 10 & 1,61 & 3,37 \\
\hline Densidade aparente $\left(\mathrm{kg} / \mathrm{m}^{3}\right)$ & 10 & 370,00 & 9,45 . \\
\hline Porosidade $(\%)$ & 10 & 76,98 & 3,58 \\
\hline $\begin{array}{l}\text { Poder calorifico superior } \\
\text { (kcal/kg) }\end{array}$ & 5 & 4987,80 & 4,08 \\
\hline Teor matérias voláteis (\%) & 5 & 52,92 & 1,48 \\
\hline Teor de cinzas ( $\left(\frac{0}{0}\right)$ & 5. & 20,89 & 5,28 \\
\hline Teor de carbono fixo ( $(\%)$ & 5 & 26,18 & 2,81 \\
\hline Teor de carbono total ( $\left(\frac{\circ}{2}\right)$ & 3 & 32,97 & 2,58 \\
\hline
\end{tabular}

4.2. Resultados da pirólise da turfa

A Tabela 5 apresenta globalmente os resultados médios desses rendimentos, enquanto a Tabela 6 apresenta os resultados globais dos valores de F das análises de va- 
TABELA 5. Resultados médios da pirölise da turfa em rendimento gravimétrico ${ }^{1}$.

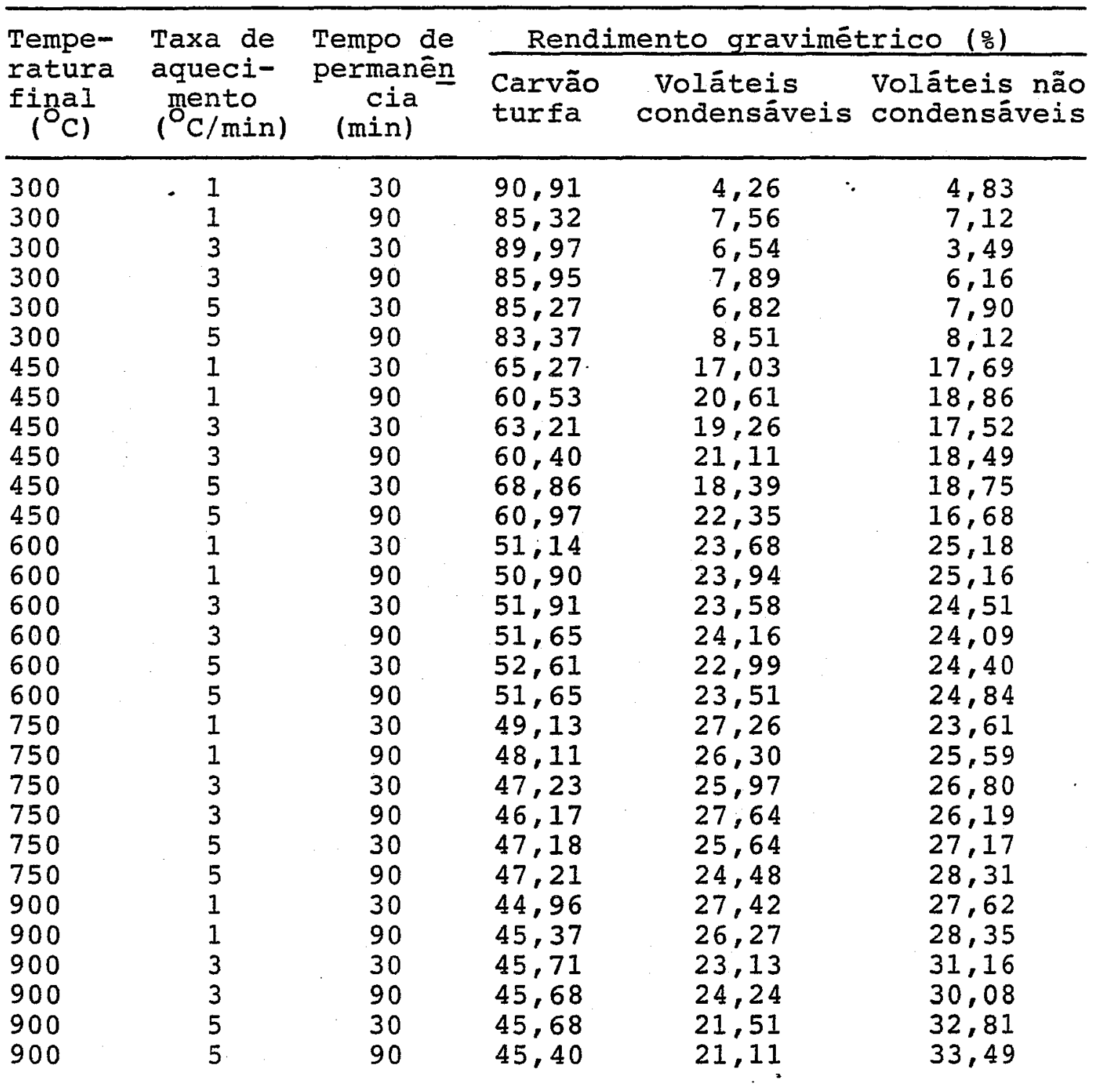

$1_{\text {Médias de duas repetições. }}$ 
riância desses resultados. Convém mencionar que os resultados individuais obtidos bem como suas análises de variância são apresentaços nas Tabelas de 24 a 27 do Apêndice.

TABELA 6. Valores de F para rendimento gravimétrico dos produtos da pirólise da turfa

\begin{tabular}{lrrr}
\hline Causa de variação & \multicolumn{1}{c}{$\begin{array}{l}\text { Carvão } \\
\text { turfa }\end{array}$} & $\begin{array}{r}\text { Voláteis } \\
\text { condensav. }\end{array}$ & $\begin{array}{r}\text { Voláteis não } \\
\text { condensáveis }\end{array}$ \\
\hline Temperatura final (A) & $9431,05 * *$ & $2046,17 * *$ & $1703,27 * *$ \\
Taxa de aquecimento (B) & $12,36 * *$ & $14,27 * *$ & $29,18 * *$ \\
Tempo de permanēncia (C) $107,71 * *$ & $50,14 * *$ & $6,87 *$ \\
Interação A X B & $14,28 * *$ & $26,17 * *$ & $11,71 * *$ \\
Interação A X C & $24,92 * *$ & $18,61 * *$ & $2,66 \mathrm{~ns}$ \\
Interação B x C & $5,19 *$ & $0,59 \mathrm{~ns}$ & $2,89 \mathrm{~ns}$ \\
\hline $\begin{array}{l}\text { Coeficiente de } \\
\text { variação (\%) }\end{array}$ & 1,03 & 2,94 & 2,76 \\
\hline
\end{tabular}

ns = não significativo

* = significativo ao nivel de $5 \%$ de probabilidade

** = significativo ao nivel de $1 \%$ de probabilidade

Quando os valores de $F$ da Tabela 6 mostraram-se significativos, procedeu-se ao desdobramento dos valores 
médios dos rendimentos para uma melhor visualização e discus são dos resultados. Tais desdobramentos são apresentados nas Tabelas de 7 a 9 .

As Figuras de 2 a 4 apresentam ilustrações so bre os efeitos dos fatores sobre os rendimentos' de produtos.

Com base nos valores de $F$ da anālise de variância apresentados na Tabela 6 , observa-se um efeito altamente significativo dos fatores temperatura final, taxa de aquecimento e tempo de permanência na temperatura final no rendimento gravimétrico do carvão de turfa. As interações entre estes fatores tambēm apresentaram significância estatistica.

Observa-se a ocorrência de uma perda gradativa de massa de turfa na forma de voláteis em função do aumen to da temperatura de degradação. Mencione-se que nesse gradiente ocorreram maiores perdas de massa durante os aquecimentos nas temperaturas mais baixas que nos aquecimentos nas temperaturas mais elevadas. Este comportamento sugere que nas temperaturas mais baixas, destacando a de $450^{\circ} \mathrm{C}$, processa-se uma série de reações e transformações quimicas mais in tensamente em relação aquelas ocorridas nas maiores temperaturas. De fato, de 600 a $900^{\circ} \mathrm{C}$ continuou havendo quedas gra dativas no rendimento gravimétrico de carvão, todavia tenden do para uma estabilização. 
TABELA 7. Comparação das médias de rendimento gravimétrico - dos produtos da turfa em função da temperatura final e taxa de aquecimento.

\begin{tabular}{|c|c|c|c|c|c|}
\hline \multirow[t]{2}{*}{ Parāmetro. } & \multirow{2}{*}{$\begin{array}{l}\text { Tempe- } \\
\text { ratura } \\
\text { final } \\
\left({ }^{\circ}\right)\end{array}$} & \multicolumn{4}{|c|}{$\begin{array}{c}\text { Taxa de aquecimento } \\
(\mathrm{C} / \text { minuto })\end{array}$} \\
\hline & & 1 & 3 & 5 & \\
\hline \multirow{5}{*}{$\begin{array}{l}\text { Rendimento em carvão } \\
\text { de turfa }(\%)\end{array}$} & 300 & $88,12 \mathrm{aA}^{*}$ & $87,96 \div a A$ & 84,32 & $a B$ \\
\hline & 450 & $62,91 \mathrm{bA}$ & $61,81 \mathrm{bB}$ & 61,91 & $\mathrm{bB}$ \\
\hline & 600 & $51,02 \mathrm{CB}$ & $51,78 \mathrm{CA}$ & 52,13 & $C A$ \\
\hline & 750 & $48,62 \mathrm{dA}$ & $46,70 \mathrm{~dB}$ & 47,19 & $\mathrm{~dB}$ \\
\hline & 900 & 45,17 eA & 45,69 eA & 45,54 & eA \\
\hline \multirow{5}{*}{$\begin{array}{l}\text { Rendimento em } \\
\text { voláteis con- } \\
\text { densáveis ( } \%)\end{array}$} & 300 & $5,91 \mathrm{~dB}$ & $7,21 \mathrm{dA}$ & 7,67 & eA \\
\hline & 450 & $18,22 \mathrm{CB}$ & $20,19 \mathrm{CA}$ & 20,37 & $\mathrm{dA}$ \\
\hline & 600 & $23,81 \mathrm{bA}$ & $23,87 \mathrm{bA}$ & 23,25 & $\mathrm{bB}$ \\
\hline & 750 & 26,78 aA & 26,81 aA & 25,06 & $a B$ \\
\hline & 900 & 26,85 aA & $23,68 \mathrm{bB}$ & 21,31 & $c C$ \\
\hline \multirow{5}{*}{$\begin{array}{l}\text { Rendimento em } \\
\text { volāteis não } \\
\text { condensáveis }(\%)\end{array}$} & 300 & $5,97 \mathrm{eB}$ & $4,83 \mathrm{ec}$ & 8,01 & \\
\hline & 450 & $18,27 \mathrm{dA}$ & $18,00 \mathrm{dA}$ & 17,71 & $d A$ \\
\hline & 600 & $25,17 \mathrm{CA}$ & $24,30 \mathrm{cA}$ & 24,62 & $C A$ \\
\hline & 750 & $24,60 \mathrm{bc}$ & $24,49 \mathrm{bB}$ & 27,22 & $\mathrm{bA}$ \\
\hline & 900 & $27,78 \mathrm{aC}$ & $30,62 \mathrm{aB}$ & 33,15 & $a A$ \\
\hline
\end{tabular}


TABELA 8. Comparação de médias de rendimento gravimētrico em carvão e voláteis condensāveis em função da temperatuia final e tempo de permanência.

\begin{tabular}{|c|c|c|c|c|}
\hline \multirow[t]{2}{*}{ Parāmetro } & \multirow{2}{*}{$\begin{array}{c}\text { Temperatura } \\
\text { final } \\
\left({ }^{\circ} \mathrm{C}\right)\end{array}$} & \multicolumn{3}{|c|}{$\begin{array}{c}\text { Tempo de permanência } \\
\text { (minutos) }\end{array}$} \\
\hline & & 30 & & 90 \\
\hline \multirow{5}{*}{$\begin{array}{l}\text { Rendimento em carvão } \\
\text { de turfa }\left(\frac{0}{0}\right)\end{array}$} & 300 & 88,72 & $a A^{*}$ & $84,88 \quad \mathrm{aB}$ \\
\hline & 450 & 63,78 & $\mathrm{bA}$ & $60,64 \mathrm{bB}$ \\
\hline & 600 & 51,88 & $c A$ & $51,40 \mathrm{cA}$ \\
\hline & 750 & 47,84 & $d A$ & $47,17 \mathrm{dA}$ \\
\hline & 900 & 45,45 & $\mathrm{eA}$ & 45,48 eA \\
\hline \multirow{5}{*}{$\begin{array}{l}\text { Rendimento em voláteis } \\
\text { condensáveis }\left(\frac{\circ}{0}\right)\end{array}$} & 300 & 5,87 & $d B$ & $7,99 \mathrm{dA}$ \\
\hline & 450 & 18,23 & $\mathrm{CB}$ & $21,36 \mathrm{cA}$ \\
\hline & 600 & 23,42 & $\mathrm{bA}$ & $23,87 \mathrm{bA}$ \\
\hline & 750 & 26,29 & $a A$ & $29,14 \mathrm{aA}$ \\
\hline & 900 & 24,02 & $\mathrm{bA}$ & $23,88 \mathrm{bA}$ \\
\hline
\end{tabular}

* As médias na coluna com mesma letra minúscula ou na linha com mesma letra maiúscula não diferem entre si pelo teste de Waller-Duncan. 
TABELA 9. Comparação de médias de rendimento gravimétrico de carvão em função da taxa de aquecimento e tempo de permanência.

\begin{tabular}{|c|c|c|c|c|}
\hline \multirow[t]{2}{*}{ Parāmetro. } & \multirow{2}{*}{$\begin{array}{c}\text { Taxa de } \\
\text { aquecimento } \\
(\mathrm{C} / \mathrm{min})\end{array}$} & \multicolumn{3}{|c|}{$\begin{array}{c}\text { Tempo de permanência } \\
\text { (minutos) }\end{array}$} \\
\hline & & 30 & & 90 \\
\hline \multirow{3}{*}{$\begin{array}{l}\text { Rendimento em carvão } \\
\text { de turfa }(\%)\end{array}$} & 1 & 60,27 & $a A^{*}$ & $58,05 \mathrm{aB}$ \\
\hline & 3 & 59,61 & $\mathrm{bA}$ & $57,97 \mathrm{aB}$ \\
\hline & 5 & 58,72 & $C A$ & $57,72 \mathrm{aB}$ \\
\hline
\end{tabular}

* As médias na coluna com mesma letra minūscula ou na linha com mesma letra maiúscula não diferem entre si pelo teste de Waller-Duncan.

- efeito da temperatura final observado no rendimento de carvão de turfa assemelha aos encontrados na literatura: que trata de pirólise de material 'orgânico. BEL'KEVICH et alii (1971) e FUCHSMAN (1980), trabalhando com pirólise de turfa, observaram que o aumento na temperatura facilita a dissociação de seus componentes com a libe ração de voláteis e consequentemente acarretando um decréscí. mo no cendimento em carvão.

O rendimento gravimétrico em carvão de turfa mostrou-se ainda influenciado pela taxa de aquecimento e tem 


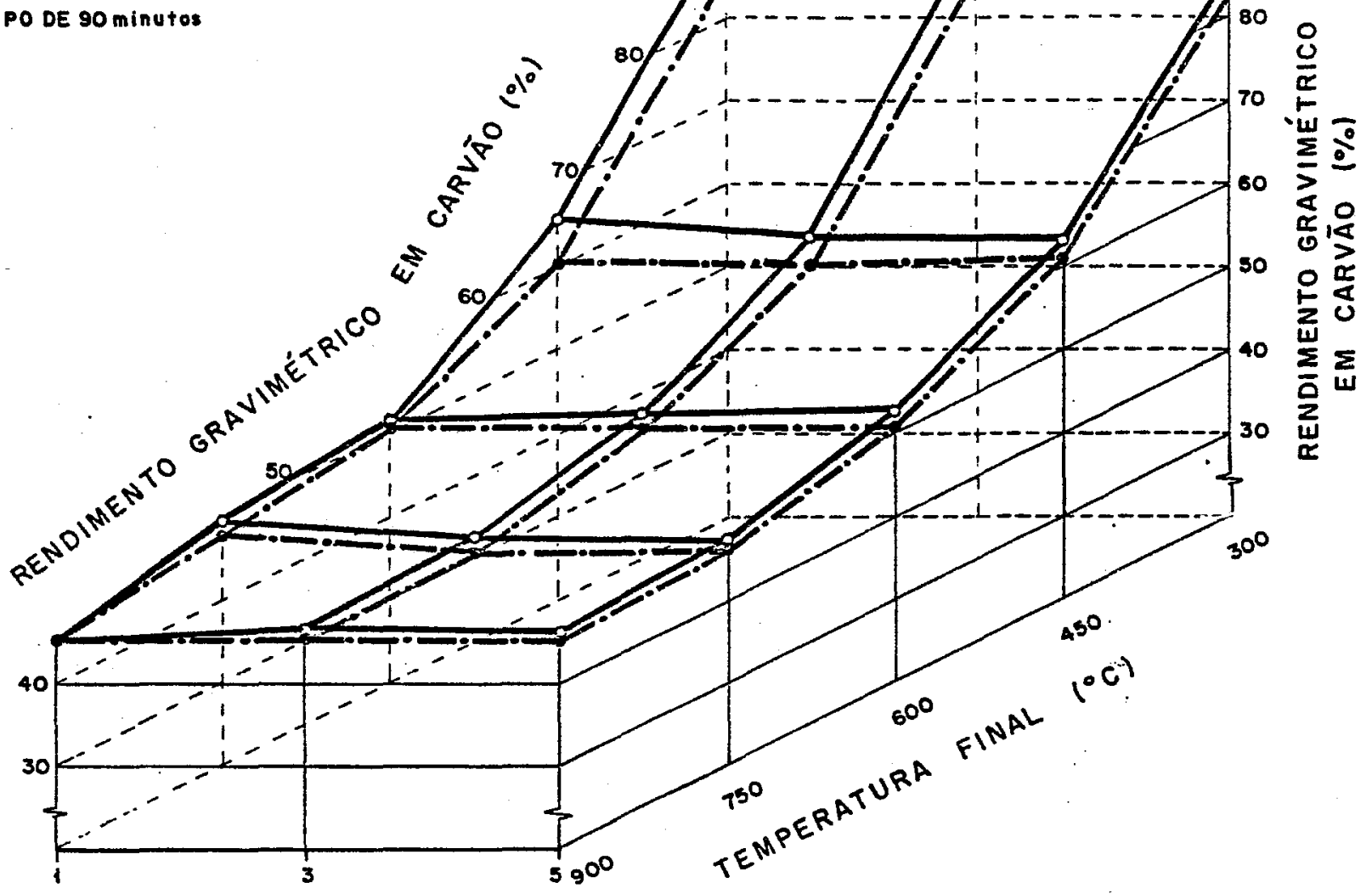

TAXA DE AQUECIMENTO

$\left({ }^{\circ} \mathrm{C} / \mathrm{minuto}\right)$

FIGURA 2. Efeito da taxa de aquecimento, temperatura final e tempo de permanência no rendimento gravimétrico de carvão de turfa. 


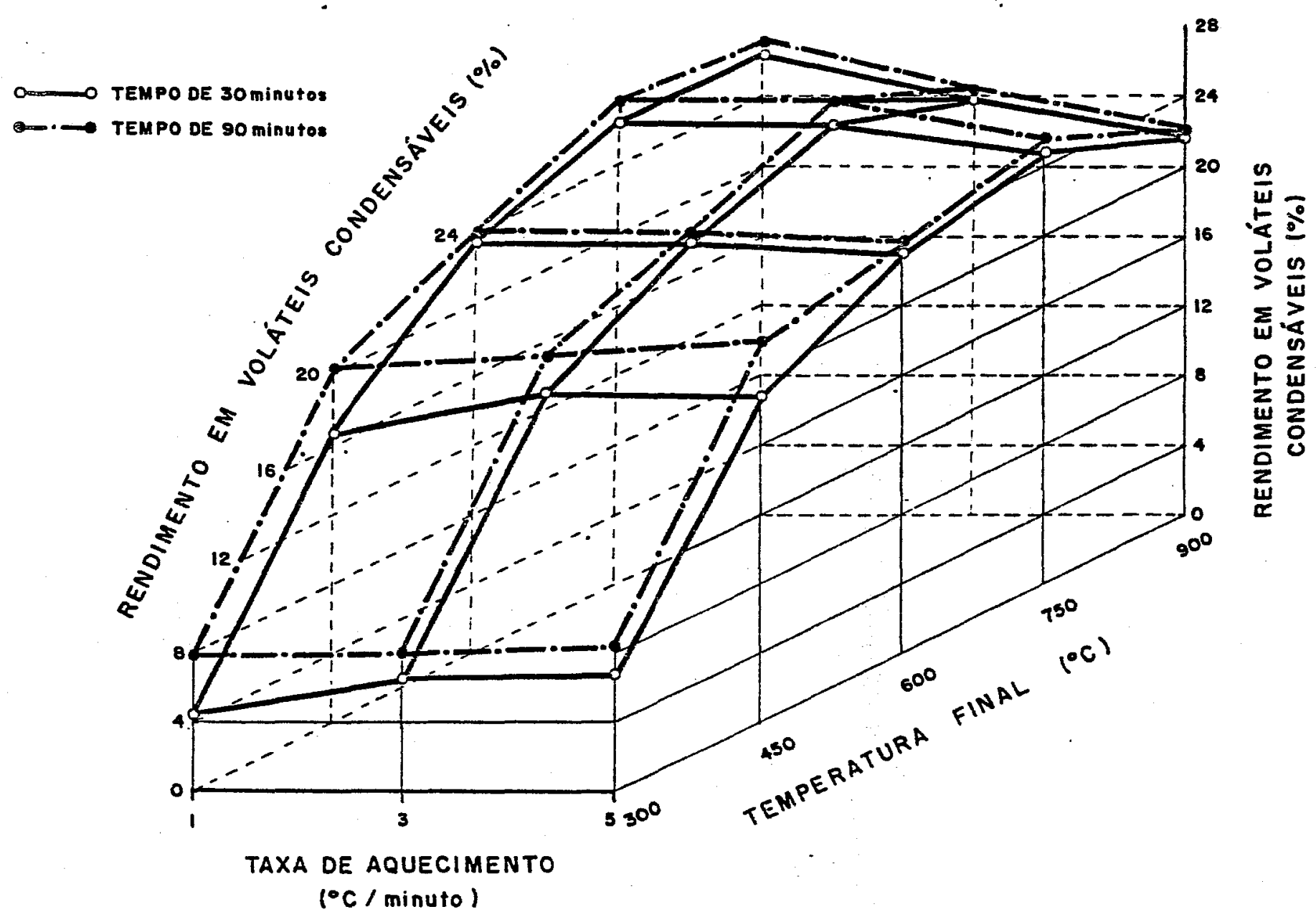

FIGURA 3. Efeito da taxa de aquecimento, temperatura final e tempo de permanēncia no rendimento gravimétrico de voláteis condensāveis. 
po de permanência na temperatura final conforme pode ser observado na Tabela 7. Verifica-se que o aumento da taxa de aquecimento foi acompanhado de uma diminuição do rendimento de carvão de turfa, particularmente nas menores temperaturas finais. Isto pode ser melhor visualizado na Figura 2. FUCHSMAN (1980) explica que em taxas de aquecimento mais rápidas a turfa tende a expelir volāteis mais abruptamente impedindo uma maior recombinação destes em compostos de alto peso molecular. Havendo formação destes compostos mais estā veis em menor quantidade, há um decréscimo no rendimento em carvão.

O tempo de permanência na temperatura final provocou efeito no rendimento gravimétrico de carvão de maneira mais ou menos semelhante aquele causado pela taxa. de aquecimento, o que pode ser melhor visualizado nas Tabelas 8 e 9.

No período de degradação mais curto, 30 minutos, o rendimento em carvão foi maior que aquele conseguido a 90 minutos, particularmente nas menores temperaturas. Por tanto, deduz-se que em periodos mais extensos, nảs condições de tempẹraturas mencionadas, hã mais oportunidade de eliminação de voláteis na turfa e por conseguinte reduz-se o seu rendimento em carvão. 
temperatura final induz efeito bem mais forte no rendimento em carvão que os demais fatores testados.

Os valores encontrados para rendimento gravimétrico de carvão de turfa, no geral, foram superiores aos normalmente encontrados na literatura. IARBALETRIER (s.d.), CHRISTIASSON (1953), TRONT (1958) e FUCHSMAN (1980) encontra ram valores em torno de $50 \%$ para rendimento gravimétrico de carvão trabalhando com turfa em temperaturas proximas de $500^{\circ} \mathrm{C}$. Por sua vez, SIIVA \& BRITO (1987) obtiveram rendimen to em carvão de turfa de $52,1,62,2$ e $62,4 \%$, respectivamente para turfas contendo $3,4,21,3$ e 18,9\% de teor de cinzas, quando carbonizadas a $450-500^{\circ} \mathrm{C}$ e taxa de aquecimento média de aproximadamente $2^{\circ} \mathrm{C} /$ minuto. Verifica-se pois, que o apa rente maior rendimento encontrado se deve ao teor de cinzas relativamente alto na turfa do presente estudo, que atuou como material inerte, uma vez que para efeito de cálculo des contando o seu teor, chega-se a quantidade de carvão de turfa produzi da semelhante aquelas da literatura em condições próximas de pirólise.

Com relação ao rendimento em volāteis condensáveis e não condensáveis, considerando os valores de $F$ da análise de variāncia da Tabela 6 , verifica-se que os fatores temperatura final, taxa de aquecimento e tempo de permanência induziram efeitos estatisticamente significativos. 
Os rendimentos em voláteis condensáveis e não condensáveis, também estatisticamente, sofreram efeitos da interação temperatura final e taxa de aquecimento, enquanto que a interação temperatura e tempo de permanência influenciou apenas o rendimento de voláteis condensáveịs. Não houve influência da interação taxa de aquecimento e tempo de permanēncia na produção dos voláteis mencionados.

Como esperava-se, o rendimento gravimétrico em voláteis procedeu-se de maneira inversa ao de carvão de turfa. Foi observado que, como regra geral, quando aumenta-se a temperatura final do processo, resulta-se em um aumento gradativo na perda de voláteis pela turfa, os quais enriquecem as fases liquida e gasosa. O efeito foi mais pronunciado quando o processo ocorreu em temperaturas mais baixas. Este comportamento está de acordo com as observaçōes de SHAPATINA et alii (1960) e CHUKANOV et alii (1962) para os quais, o rendimento em voláteis aumenta gradualmente com a temperatura mas logo após atingir $500-600^{\circ} \mathrm{C}$, a quantidade destes produtos formados varia muito pouco. Destarte que nas temperaturas mais altas - 600 , a 750 e $900^{\circ} \mathrm{C}$, predominou -se maior produção de voláteis não-condensáveis. Esta maior produção destes voláteis, após $600^{\circ} \mathrm{C}$, se deve à ocorrência de gaseificação do carvão. Até 500-600 C, desprende-se gases oxigenados e gases hidrogenados, onde sobrepõe-se a produção de hidrocarbonetos. Não sendo interrompido o prọesso 
e a temperatura ultrapassa valores acima desta faixa, como consequência, o găs hidrogēnio torna-se predominante. Esta deve ser a razão pela qual se explica, de certa forma, a geração ligeiramente maior de voláteis não-condensāveis astempe raturas mais altas. De maneira semelhante, FUCWSMAN (1980) verificou que a degradação da turfa tende a completar-se em torno de $600-700^{\circ} \mathrm{C}$, mas entre as temperaturas de 700 e $900^{\circ} \mathrm{C}$ ainda pode haver eliminação de produtos voláteis, possivel mente predominando o hidrogēnio. Estes produtos devem ser gerados devido a gaseificação do carvão que ocorre nesta fai xa de temperatura.

Os resultados obtidos na Tabela 7 mostraram que, com o aumento da taxa de aquecimento, ocorreu uma relativa e ligeira tendência do rendimento gravimétricn de voláteis condensāveis aunentar nas temperaturas mais baixas e, contrariamente, diminuir nas mais altas. Mas no geral, predominou-se uma queda suave na produção relativa de voláteis condensáveis com o aumento na taxa de aquecimento. Nas mesmas condições, o comportamento de voláteis não condensáveis foi, de maneira geral, aumentar-se com a elevação da taxa de aquecimento, notadamente nas temperaturas de 750 e $900^{\circ} \mathrm{C}$.

Pelos resultados ob́tidos para o carvão de turfa eca dese esperar, que $\circ$ tempo de permanēncia na temperatura final exercesse influência no rendimento de voläteis. Verifica-se que no período de 90 minutos houve maior produção de voíáteis 
quando comparado ao de 30 minutos, somente nas temperaturas de 300 e $450^{\circ} \mathrm{C}$.

De todo o observado e comentado, depreende-se que a temperatura final induziu efeito mais destacado, na pirólise da turfa para proọução de carvão de turfa e volāteis que os fatores tempo de permanēncia e taxa de aquecimento.

Em concordância com o observado, foi verifica do uma correlação significativa com coeficiente de correlação de $-0,9815$ entre rendimento em carvão de turfa e rendi mento em voláteis.

4.3. Taxa de redução granulométrica da turfa

A Tabela 10 apresenta os resultados médios para taxa de redução granulométrica da turfa frente a pirólise, enquanto na Tabela 11, tem-se os valores de F da anālise de variāncia.

A Tabela 12 mostra a relação entre temperatura final e taxa de aquecimento na redução granulómētrica do carvão. 
TABELA 10. Resultados médios da taxa de redução granulométrica da turfa frente a pirólise $e^{l}$.

\begin{tabular}{|c|c|c|c|}
\hline $\begin{array}{c}\text { Temperatura } \\
\text { final } \\
\left({ }^{\mathrm{C}}\right)\end{array}$ & $\begin{array}{l}\text { Taxa de } \\
\text { aquecimento } \\
\left(0^{\circ} / \mathrm{min}\right)\end{array}$ & $\begin{array}{l}\text { Tempo de } \\
\text { permanēncia } \\
\text { (min) }\end{array}$ & $\begin{array}{l}\text { Taxa de redução } \\
\text { granulométrical } \\
\quad \because\end{array}$ \\
\hline $\begin{array}{l}300 \\
300 \\
300 \\
300 \\
300 \\
300 \\
450 \\
450 \\
450 \\
450 \\
450 \\
450 \\
600 \\
600 \\
600 \\
600 \\
600 \\
600 \\
750 \\
750 \\
750 \\
750 \\
750 \\
750 \\
900 \\
900 \\
900 \\
900 \\
900 \\
900\end{array}$ & $\begin{array}{l}1 \\
1 \\
3 \\
3 \\
5 \\
5 \\
1 \\
1 \\
3 \\
3 \\
5 \\
5 \\
1 \\
1 \\
3 \\
3 \\
5 \\
5 \\
1 \\
1 \\
3 \\
3 \\
5 \\
5 \\
1 \\
1 \\
3 \\
3 \\
5\end{array}$ & $\begin{array}{l}30 \\
90 \\
30 \\
90 \\
30 \\
90 \\
30 \\
90 \\
30 \\
90 \\
30 \\
90 \\
30 \\
90 \\
30 \\
90 \\
30 \\
90 \\
30 \\
90 \\
30 \\
90 \\
30 \\
90 \\
30 \\
90 \\
30 \\
90 \\
30 \\
90\end{array}$ & $\begin{array}{l}0,802 \\
0,882 \\
0,507 \\
0,557 \\
0,460 \\
0,362 \\
0,772 \\
0,894 \\
0,716 \\
0,780 \\
0,748 \\
0,914 \\
0,806 \\
0,793 \\
0,633 \\
0,645 \\
0,650 \\
0,616 \\
0,887 \\
0,873 \\
0,774 \\
0,794 \\
0,589 \\
0,599 \\
0,791 \\
0,903 \\
0,645 \\
0,659 \\
0,569 \\
0,474\end{array}$ \\
\hline
\end{tabular}

1 Médias de duas repetições, expressa em arc sen $\sqrt{x / 100}$. 
TABELA 11. Valores de $F$ para taxa de redução granulométrica da turfa frente a pirólise.

Causa da variação

Valores de $F$

Temperatura final (A)

$6,69 * *$

Taxa de aquecimento (B)

$27,17 * *$

Tempo na temperatura final (C)

0,91 ns

Interação A x B

$2,78 *$

Interação $\mathrm{A} \times \mathrm{C}$

$0,70 \mathrm{~ns}$

Interação B X C

$0,51 \mathrm{~ns}$

Coeficiente de variação $(\%)$

15,14

ns = não significativo

* = significativo ao nivel de $5 \%$ de probabilidade ** = significativo ao nivel de $1 \%$ de probabilidade 
TABELA 12. Comparação de mēdias para taxa de redução granulométrica da turfa frente a interação taxa de aquecimento e temperatura final.

\begin{tabular}{llll}
\hline $\begin{array}{c}\text { Temperatura } \\
\text { final } \\
\text { ( } \mathrm{C})\end{array}$ & \multicolumn{4}{c}{ Taxa de reducão granulométrica } \\
\cline { 2 - 4 } & $1^{\circ} \mathrm{C} /$ minuto & $3^{\circ} \mathrm{C} /$ minuto & $5^{\circ} \mathrm{C} /$ minuto \\
\hline 300 & $0,842 \mathrm{aA}$ & $0,532 \mathrm{cB}$ & $0,411 \mathrm{cC}$ \\
450 & $0,833 \mathrm{aA}$ & $0,748 \mathrm{abAB}$ & $0,732 \mathrm{aB}$ \\
600 & $0,800 \mathrm{aA}$ & $0,639 \mathrm{bB}$ & $0,633 \mathrm{abB}$ \\
750 & $0,880 \mathrm{aA}$ & $0,784 \mathrm{aB}$ & $0,595 \mathrm{bC}$ \\
900 & $0,848 \mathrm{aA}$ & $0,652 \mathrm{bB}$ & $0,525 \mathrm{bcC}$
\end{tabular}

1 Médias expressa em arc seno $\sqrt{\mathrm{x} / 100}$.

* As médias na coluna com mesma letra minúscula ou na linha com mesma letra maiúscula não diferem entre si pelo teste de Waller-Duncan.

Os resultados individuais de taxa de redução granulométrica de cada tratamento bem como sua análise estatistica encontram-se, respectivamente, nas Tabelas 29 e 30 do Apēndice. Nas Tabelas 28 e 29 do Apêndice tambēm são apresentados os valores individuais da fração de turfa e carvão acima de 10 milimetros usadas nos cálculos da taxa de re dução granulométrica.

As ilustrações dos resultados médios considerando a temepratura final e taxa de aquecimento estão na Figura 5. 


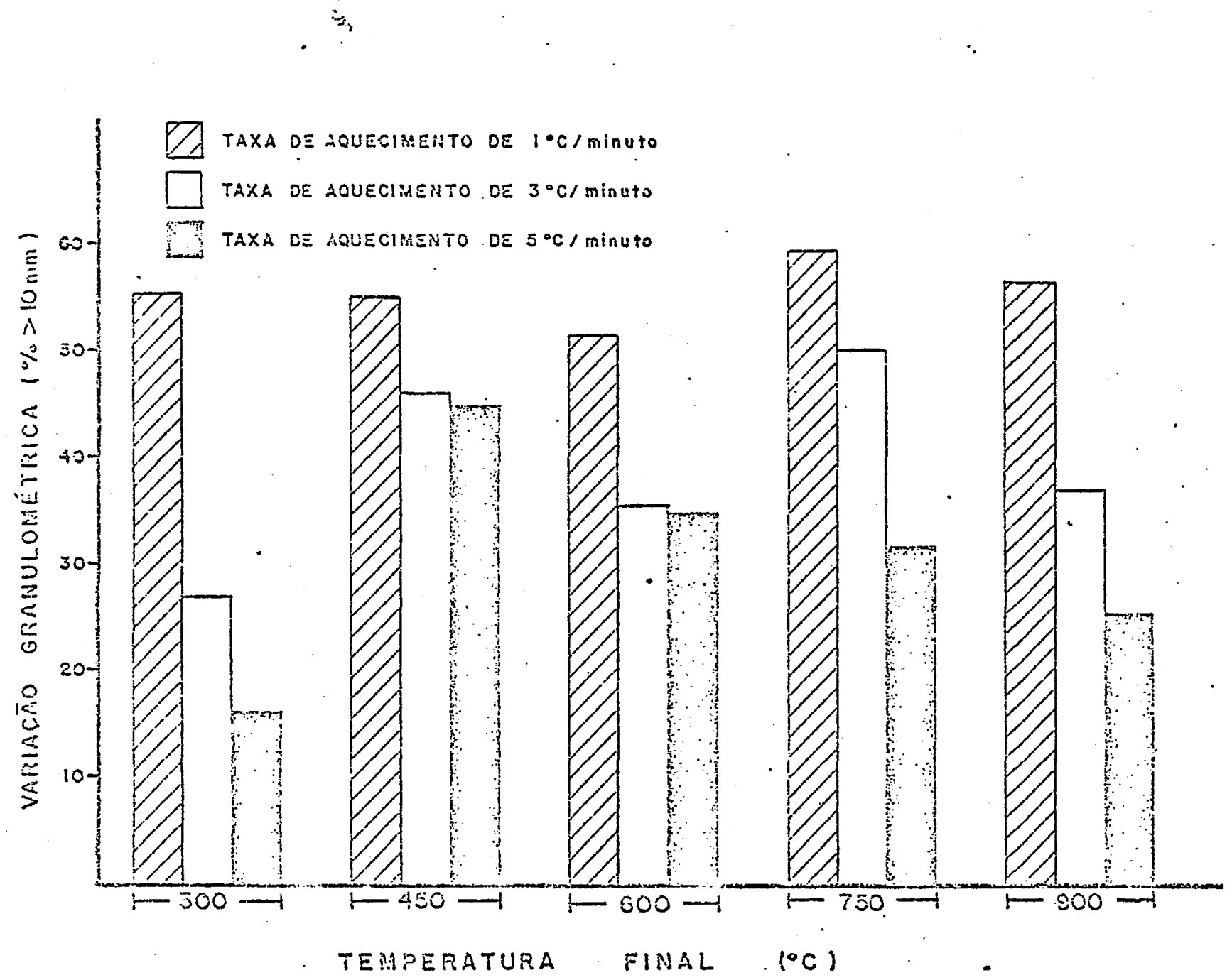

FIGURA 5. Efeito da taxa de aquecimento e temperatura final na taxa de redução granulomētrica da turfa. 
Com base nos valores de F, verifica-se que houve efeito significativo somente dos fatores temperatura final e taxa de aquecimento e da interação ocorrida entre es tes na taxa de redução granulométrica.

Na média, independente dos efeitos especificos de cada fator, ocorreu uma redução granulométrica em tor no de 40 a $45 \%$. De certa forma, este comportamento esta de acordo com observações feitas por FUCHSMAN (1980). Tal autor menciona que a redução no tamanho da turfa inicia-se a $250^{\circ} \mathrm{C}$ e atinge o gradiente máximo em torno de 450 e após $500^{\circ} \mathrm{C}$ ocorre pouca redução.

o fator que mais contribuiu para a diminuição na granulometrica da turfa frente a termodegradação, como po de ser verificado na Tabela 12 , foi a taxa de aquecimento.

Esta sensivel redução na granulometria em função da pirólise deve estar relacionada, muito pró vavelmente, com a taxa e a quantidade de voláteis eliminados durante o processo, bem como fenômenos ligados à ruptura e fragmentação da turfa. 


\subsection{Caracteristicas do carvão de turfa}

o carvão de turfa foi caracterizado através das determinações da densidade verdadeira, densidade aparente, porosidade, poder calorifico superior e anālise imediata. Logo a seguir, são apresentados e discutidos os resultados individualmente para cada parāmetro analisado. Enfatiza-se os efeitos que os fatores temperatura final, taxa de aquecimento e tempo de permanēncia na temperatura final, empregados na pirólise da turfa, induziram nas caracteristicas do seu carvão.

\subsubsection{Densidade e porosidade do carvão de turfa}

As condiçōes de pirólise empregadas no presente estudo influenciaram o comportamento da densidade verdadeira e da densidade aparente do carvão de turfa, notadamente a temperatura final.

A Tabela 13 apresenta os resultados médios globais enquanto na Tabela 14 é mostrado os valores de F obti dos nas análises de variāncia.

No Apēndice, a Tabela 31 lista os dados individuais dos tratamentos para densidade verdadeira, densidade 
TABELA 13. Resultados médios de densidade e porosidade do carvão de turfa.

\begin{tabular}{|c|c|c|c|c|c|}
\hline $\begin{array}{l}\text { Tempe- } \\
\text { ratura } \\
\text { final } \\
\left({ }^{\circ} \mathrm{C}\right)\end{array}$ & $\begin{array}{l}\text { Taxa de } \\
\text { aqueci- } \\
\text { mento } \\
(\text {. C/min) }\end{array}$ & $\begin{array}{c}\text { Tempo de } \\
\text { permanēn } \\
\text { cia } \\
\text { (min) }\end{array}$ & $\begin{array}{c}\text { Densidade } \\
\text { verdadeira } \\
\left(\mathrm{g} / \mathrm{cm}^{3}\right)\end{array}$ & $\begin{array}{l}\text { Densidade } \\
\text { aparente } \\
\left(\mathrm{kg} / \mathrm{m}^{3}\right)\end{array}$ & $\begin{array}{c}\text { Porosidade } \\
(\%)\end{array}$ \\
\hline $\begin{array}{l}300 \\
300 \\
300 \\
300 \\
300 \\
300 \\
450 \\
450 \\
450 \\
450 \\
450 \\
450 \\
600 \\
600 \\
600 \\
600 \\
600 \\
600 \\
750 \\
750 \\
750 \\
750 \\
750 \\
750 \\
900 \\
900 \\
900 \\
900 \\
900 \\
900\end{array}$ & $\begin{array}{l}1 \\
1 \\
3 \\
3 \\
5 \\
5 \\
1 \\
1 \\
3 \\
3 \\
5 \\
5 \\
1 \\
1 \\
3 \\
3 \\
5 \\
5 \\
1 \\
1 \\
3 \\
3 \\
5 \\
5 \\
1 \\
1 \\
3 \\
3 \\
5 \\
5\end{array}$ & $\begin{array}{l}30 \\
90 \\
30 \\
90 \\
30 \\
90 \\
30 \\
90 \\
30 \\
90 \\
30 \\
90 \\
30 \\
90 \\
30 \\
90 \\
30 \\
90 \\
30 \\
90 \\
30 \\
90 \\
30 \\
90 \\
30 \\
90 \\
30 \\
90 \\
30 \\
90\end{array}$ & $\begin{array}{l}1,49 \\
1,53 \\
1,46 \\
1,49 \\
1,43 \\
1,46 \\
1,49 \\
1,55 \\
1,54 \\
1,55 \\
1,57 \\
1,59 \\
1,81 \\
1,75 \\
1,73 \\
1,72 \\
1,79 \\
1,77 \\
1,76 \\
1,80 \\
1,73 \\
1,74 \\
1,75 \\
1,79 \\
1,78 \\
1,88 \\
2,08 \\
2,11 \\
1,99 \\
2,02\end{array}$ & $\begin{array}{l}491 \\
469 \\
496 \\
531 \\
499 \\
497 \\
501 \\
553 \\
535 \\
566 \\
557 \\
513 \\
622 \\
622 \\
571 \\
606 \\
631 \\
546 \\
629 \\
627 \\
605 \\
627 \\
621 \\
616 \\
787 \\
816 \\
772 \\
746 \\
657 \\
674\end{array}$ & $\begin{array}{l}67,16 \\
69,45 \\
66,13 \\
64,33 \\
65,21 \\
66,07 \\
66,44 \\
64,22 \\
65,24 \\
63,48 \\
64,63 \\
67,71 \\
65,71 \\
64,43 \\
67,08 \\
64,88 \\
64,79 \\
69,13 \\
64,35 \\
65,27 \\
65,10 \\
64,08 \\
64,61 \\
65,65 \\
55,70 \\
56,57 \\
62,88 \\
64,76 \\
67,04 \\
66,73\end{array}$ \\
\hline
\end{tabular}

1 Médias de duas repetições. 
aparente e porosidade enquanto nas Tabelas 32 a 34 , respecti vamente, são apresentadas as análise de variância.

TABELA 14. Valores de F para densidade e porosidade do carvão, de turfa.

\begin{tabular}{lcccc}
\hline Causa da variação & $\cdot$ & $\begin{array}{c}\text { Densidade } \\
\text { verdadeira }\end{array}$ & $\begin{array}{c}\text { Densidade } \\
\text { aparente }\end{array}$ & Porosidade \\
\hline Temperatura final (A) & $253,14 * *$ & $65,95 * *$ & $5,59 * *$ \\
Taxa de aquecimento (B) & $3,74 *$ & $3,28 \mathrm{~ns}$ & $4,49 *$ \\
Tempo de permanēncia (C) & $3,80 \mathrm{~ns}$ & $0,05 \mathrm{~ns}$ & $0,26 \mathrm{~ns}$ \\
Interação A x B & $10,95 * *$ & $2,75 *$ & $5,16 * *$ \\
Interação A x C & $1,75 \mathrm{~ns}$ & $0,24 \mathrm{~ns}$ & $0,09 \mathrm{~ns}$ \\
Interação B x C & $0,32 \mathrm{~ns}$ & $1,64 \mathrm{~ns}$ & $1,75 \mathrm{~ns}$ \\
\hline Coeficiente de variạão (o) & 2,52 & 6,66 & 3,64 \\
\hline
\end{tabular}

ns = não significativo

* = significativo ao nivel de 5\% de probabilidade ** = significativo ao nivel de 1 음 de probabilidade

Quando os valores de $F$ apresentaram-se significativos, procedeu-se o declobramento dos valores médios pa ra melhor visualização e discussão dos resultados. Tal desdobramento é apresentado na Tabela 15. 
TABELA 15. Comparação de médias de densidade verdadeira, den sidade aparente e porosidade do carvão de turfa em função da temperatura final e taxa de aqueci mento.

\begin{tabular}{|c|c|c|c|c|c|}
\hline \multirow[t]{2}{*}{ Parâmetro } & \multirow{2}{*}{$\begin{array}{c}\text { Temperatura } \\
\text { final } \\
\left({ }^{\circ} \mathrm{C}\right)\end{array}$} & \multicolumn{4}{|c|}{$\begin{array}{c}\text { Taxa de aquecimento } \\
\left({ }^{\circ} \mathrm{C} / \text { minuto }\right)\end{array}$} \\
\hline & & 1 & & 3 & 5 \\
\hline \multirow{5}{*}{$\begin{array}{l}\text { Densidade } \\
\text { verdadeira } \\
\left(\mathrm{g} / \mathrm{cm}^{3}\right)\end{array}$} & 300 & 1,51 & $c A^{*}$ & $1,48 \mathrm{cA}$ & $1,46 \mathrm{dA}$ \\
\hline & 450 & 1,52 & $\mathrm{CA}$ & $1,54 \mathrm{cA}$ & $1,58 \mathrm{cA}$ \\
\hline & 600 & 1,78 & $\mathrm{bA}$ & $1,73 \mathrm{bA}$ & $1,78 \mathrm{bA}$ \\
\hline & 750 & 1,78 & $\mathrm{bA}$ & $1,74 \mathrm{bA}$ & $1,77 \mathrm{bA}$ \\
\hline & 900 & 1,88 & $a B$ & $2,05 \mathrm{aA}$ & 2,01 aA \\
\hline \multirow{5}{*}{$\begin{array}{l}\text { Densidade } \\
\text { aparente } \\
\left(\mathrm{kg} / \mathrm{m}^{3}\right)\end{array}$} & 300 & $480 \mathrm{cA}$ & & $513 \mathrm{cA}$ & $498 \mathrm{dA}$ \\
\hline & 450 & $527 \mathrm{CA}$ & & $550 \mathrm{bcA}$ & $535 \mathrm{cdA}$ \\
\hline & 600 & $622 \mathrm{bA}$ & & $588 \mathrm{bA}$ & $589 \mathrm{bcA}$ \\
\hline & 750 & $628 \mathrm{bA}$ & & $616 \mathrm{bA}$ & $619 \mathrm{abA}$ \\
\hline & 900 & 774 aA & & 757 aA & $665 \mathrm{aB}$ \\
\hline \multirow[t]{5}{*}{ Porosidade $(\%)$} & 300 & 68,31 & $\mathrm{aA}$ & $65,23 \mathrm{aA}$ & 65,64 aA \\
\hline & 450 & 65,33 & $\mathrm{aA}$ & 64,36 aA & 66,17 aA \\
\hline & 600 & 65,08 & $a A$ & 65,98 aA & 66,96 aA \\
\hline & 750 & 66,81 & $a A$ & 64,59 aA & 65,13 aA \\
\hline & 900 & 58,83 & $\mathrm{bc}$ & 63,83 aB & 66,88 aA \\
\hline
\end{tabular}

* As médias na coluna com mesma letra minúscula ou na linha com mesma letra maiúscula não diferem entre si pelo teste de Waller-Duncan.

As Figuras de 6 a 8 mostram ilustrações dos efeitos dos fatores sobre os parâmetros de densidade e porosidade. 


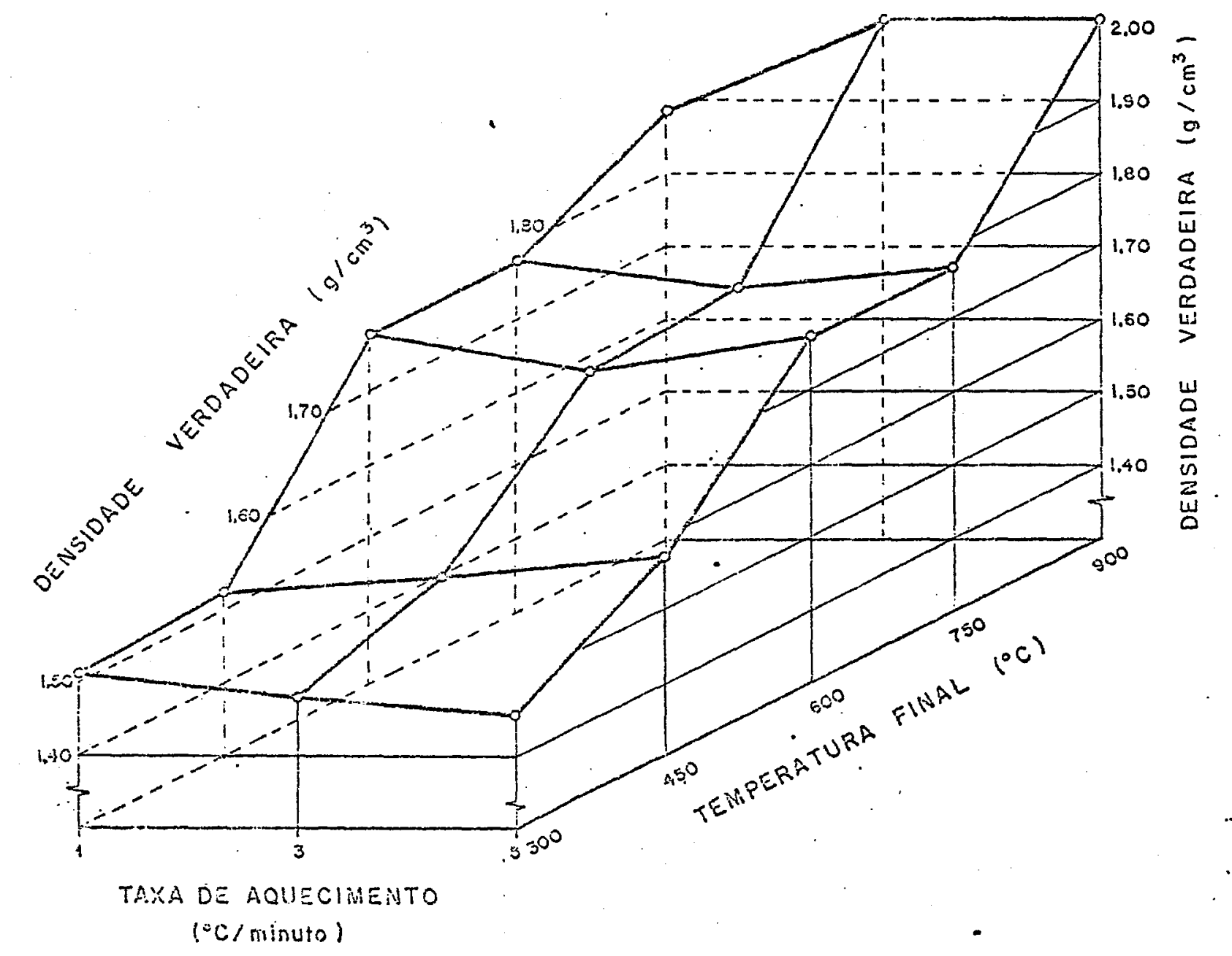

FIGURA 6. Efeito da taxa de aquecimento e temperatura filal na densidade verdadeira do carvão de turfa. 


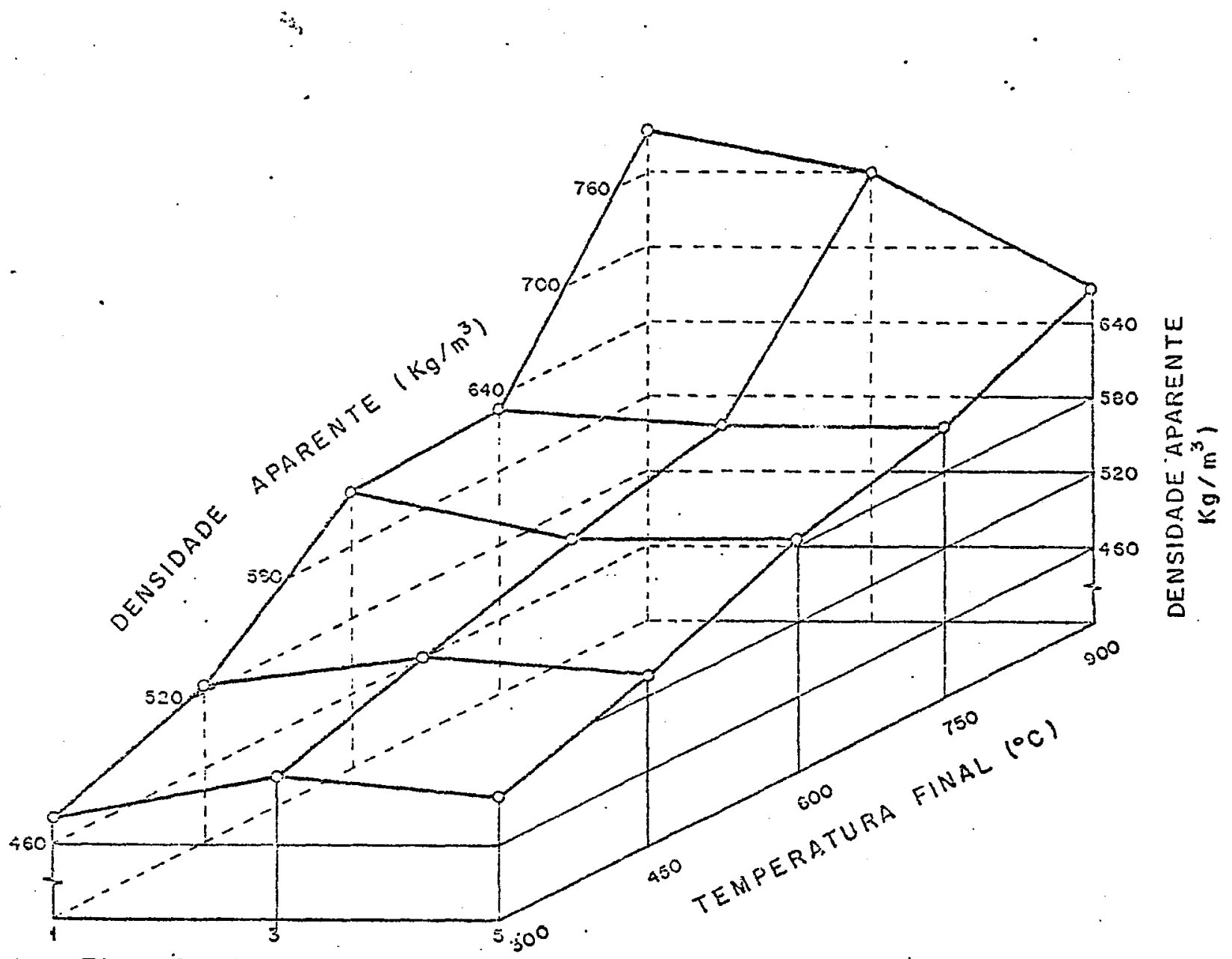

TAXA DE AQUECIMENTO

$\left({ }^{\circ} \mathrm{C} / \mathrm{minuto}\right)$

FIGURA 7. Efeito da taxa de aquecimento e temperatura final na densidade aparente do carvão de turfa. 


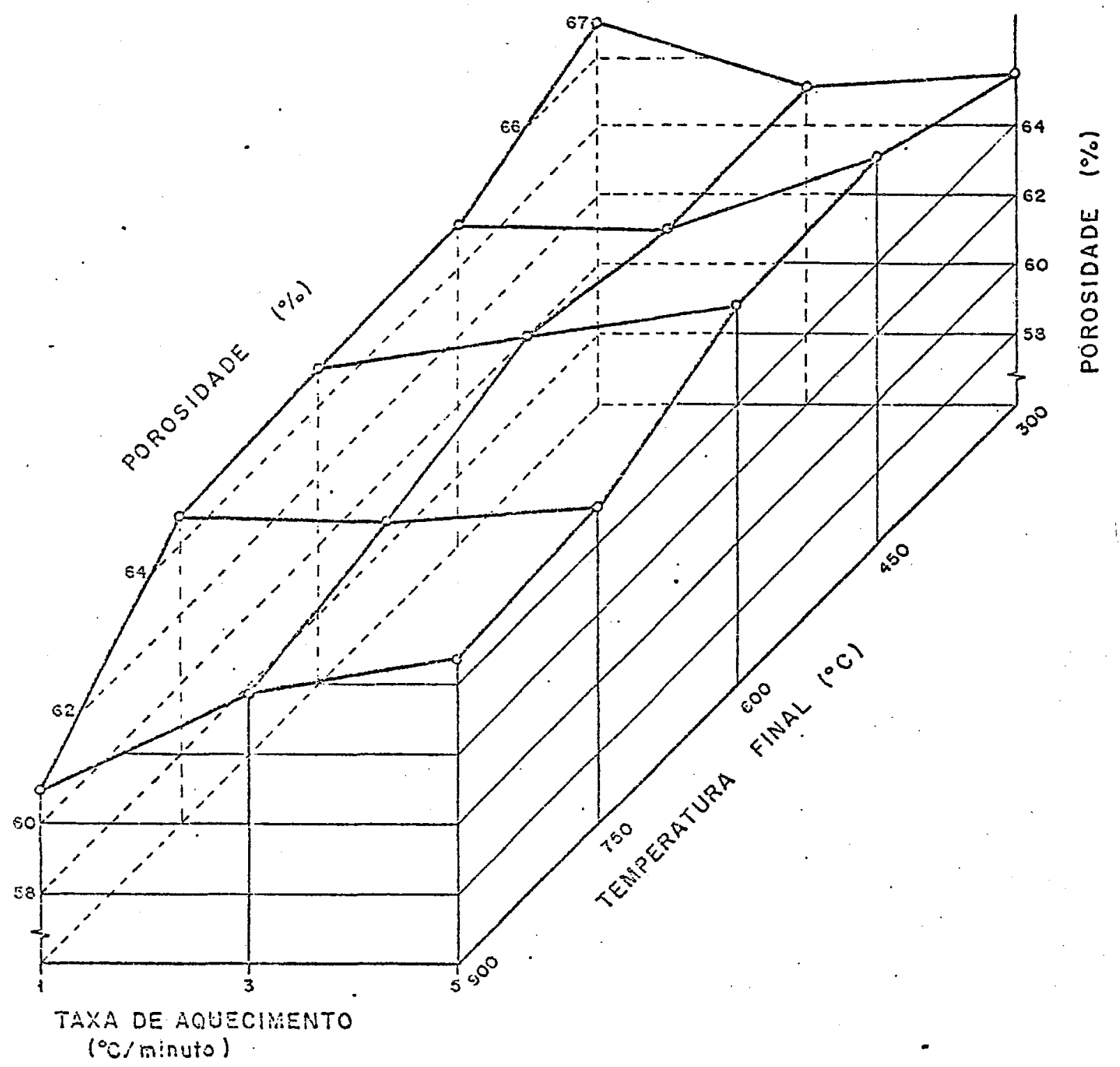

FIGURA 8. Efeito da taxa de aquecimento e temperatura final na porosidade do carvão de turfa. 
Conforme se pode notar pela Tabela 14 , a densidade verdadeira foi influenciada, estatisticamente, apenas pela temperatura final e taxa de aquecimento e pela interação ocorrida entre estes fatores.

Nas temperaturas de 300 e $450^{\circ} \mathrm{C}$ houve uma relativa redução da densidade verdadeira, considerando-se o va lor de $1,61 \mathrm{~g} / \mathrm{cm}^{3}$ originalmente existente na turfa.

Isto pode ser explicado pelo.grande efeito de perda de massa ocorridos em temperaturas mais baixas. Toda via, com a elevação da temperatura considerando toda a faixa de 300 à $900^{\circ} \mathrm{C}$, observou-se na média a tendência de acrésci mos sistemáticos na densidade verdadeira do carvão de turfa. Isto pode ser observado na Tabela 15. Este aumento foi mais acentuado na faixa de 300 à $600^{\circ} \mathrm{C}$, foi pequeno daí até $750^{\circ} \mathrm{C}$. Entretanto, de 750 a $900^{\circ} \mathrm{C}$ novamente houve um acréscimo bas tante acentuado na densidade verdadeira do carvão. Este com portamento tambēm tem sido observado para madeira. No ca so, MENDES et alii (1982) relata que isso ocorre em função' de um possivel rearranjo dos átomos de carbono resultando em uma estrutura mais ordenada. Outros autores que relatam a existência de um aumento nos valores da densidade verdadeira com a elevação da temperatura da pirólise da madeira são WENZL (1970), MENDES et alii (1982) e OLIVEIRA et alii 
(1982d). Da mesma forma SILVA (1986) com frutos de palmāceas e Grumpelt ${ }^{1}$ e Relander et alii ${ }^{2}$ citados por FUCHSMAN (1980) estudando a degradaçâo térmica da turfa.

Com relação a taxa de aquecimento, observa-se, em termos médios, que sua contribuição na variação da densidade verdadeira foi relativamente pequena.

Quanto a densidade aparente do carvão de turfa, com base nos valores de $F$ obtidos na análise de variância, listados na Tabela 14, verifica-se que somente a temperatura final e sua interação com a taxa de aquecimento produziram efeito com significāncia estatística.

Os valores médios da densidade a parente do carvão, foram maiores do que aquele encontrado originalmente na turfa. Isto pode ser explicado pela densidade verdadeira do carvão que é maior e inclusive pela ocorréncia de um teor mais elevado de cinzas do carvão, por ser este material rela tivamente inerte no processo de pirólise. Convém mencionar que a densidade das cinzas de turfa é bastante elevada. Determinação realizada à parte indicou um valor médio de $2.41 \mathrm{~g} / \mathrm{cm}^{3}$.

Quanto maiores foram as temperaturas finais

1 GRUMPELT, H. Glueckauf, 112, 599-607, 1976.

2 RELANDER, J.; HANNI, J. \& TUOMIKOSKI, E. Manufacture of metallurgical coke from peat. Outokumpu Oi, Espoo, Finland, 1975. 
de pirólise, maiores foram os valores de densidade aparente do carvão. Este aumento foi diretamente proporcional ao teor de cinzas do carvão que também foi aumentando con forme maiores foram estas temperaturas finais. Em parte, es ta è a razão para explicar o comportamento verificado para a densidade aparente.

Por outro lado, verifica-se que o carvão sofreu sensivel ređução em sua granulometria conforme já destạ cado anteriormente quando comparado com a turfa original. Es sa redução granulométrica conforme tambēm jā discutido pode ter surgido em função de uma redução de volume. Dai deduzir -se essa redução de volume proporcionando aumento da densida de aparente do carvão.

No geral, o aumento verificado na densidade aparente do carvão assemelha-se ao comportamento observado por Grumpelt ${ }^{1}$ e Relander et alii ${ }^{2}$, citados por FUCHSMAN (1980). Tais autores, por sinal, relatam que a densidade do produto sólido obtido da degradação térmica da turfa reflete o seu teor de cinzas e sua porosidade.

Na porosidade, os valores obtidos para $F$ na análise de variāncia indicam que a temperatura final e taxa

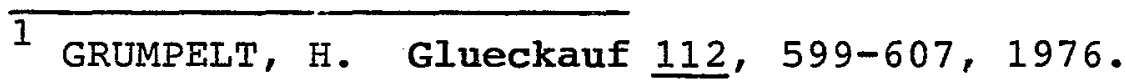
2 RELANDER, H.; HANNI, J. \& TUOMIKOSKI, E. Manufacture of metallurgical coke from peat. Outokumpu Oi, Espoo, Finland, 1975 . 
de aquecimento bem como a interação ocorrida entre os mesmos apresentaram significância estatística.

$$
\text { Observa-se que a variação da porosidade do }
$$
carvão de turfa em função das condições de termodegradação foi relativamente pequena. Isto é compreensivel, uma vez que a porosidade reflete a relação entre a densidade aparente e a densidade verdadeira. Conforme foi notado anterior mente, aquelas densidades aumentaram de maneira semelhante e proporcionalmente com a elevação da temperatura final. Como tal, a razão entre as duas modalidades de densidade foram mantidas mais ou menos constante. Por conseguinte, a porosi dade tornou-se praticamente constante diante dos tratamentos empregados.

Em relação a matēria prima original, a porosi dade do carvão foi inferior.

Para densidade e porosidade, o efeito da taxa de aquecimento foi verificado somente a $900^{\circ} \mathrm{C}$, o que pode ser uma indicação de condição de temperatura ocorrendo um maior rearranjo estrutural e possivelmente também. um maior gradiente de contração nas dimensões do carvão.

No geral, n eïeito da interação verificada en tre taxa de aquecimento e temperatura final foi pouco relevante para densidade e porosidade do carvão de turfa. 


\subsubsection{Poder calorífico superior do carvão de turfa}

Na Tabela 16 encontram-se os resultados médios para poder calorifico superior no carvão de turfa.

Os valores de $F$ obtidos na anālișe de variāncia são apresentados na Tabela 17, enquanto na Tabela 18 têm -se as médias de poder calorifico superior considerando isoladamente os fatores que compõem os tratamentos.

Nas Figuras 9 e 10 são ilustrados os resultados médios de poder calorifico superior do carvão de turfa, respectivamente, para as interaçōes ocorridas entre temperatura final e taxa de aquecimento e entre temperatura final e tempo de permanēncia.

Os resultados individuais de cada tratamento e análise de variância do poder calorifico superior do carvão de turfa estão, respectivamente, nas Tabelas ;35 e 36 do Apêndice.

Com base nos valores de $F$ apresentados na anā lise de variância, observa-se que a temperatura final e tempo de permanência induziram efeito estatisticamente significativo para poder calorífico superior. Ao contrário, as interações entre fatores bem como a taxa de aquecimento não in fluenciaram estatisticamente aquele parâmetro. 
TABELA 16. Resultados médios de poder calorifico superior pa ra carvão. de turfa.

\begin{tabular}{lccc}
\hline $\begin{array}{c}\text { Temperatura } \\
\text { final } \\
\text { (OC) }\end{array}$ & $\begin{array}{c}\text { Taxa de } \\
\text { aquecimento } \\
\text { ( C/min) }\end{array}$ & $\begin{array}{c}\text { Tempo de } \\
\text { permanencia } \\
\text { (min) }\end{array}$ & $\begin{array}{c}\text { Poder calorifico } \\
\text { superior } \\
\text { (kcal/kg) }\end{array}$ \\
\hline 300 & 1 & 30 & 5044 \\
300 & 1 & 90 & 5108 \\
300 & 3 & 30 & 5184 \\
300 & 3 & 90 & 5260 \\
300 & 5 & 30 & 5138 \\
300 & 5 & 90 & 5149 \\
450 & 1 & 30 & 5501 \\
450 & 1 & 90 & 5912 \\
450 & 3 & 30 & 5637 \\
450 & 3 & 90 & 5656 \\
450 & 5 & 30 & 5815 \\
450 & 5 & 90 & 6766 \\
600 & 1 & 30 & 6784 \\
600 & 1 & 90 & 6499 \\
600 & 3 & 30 & 6732 \\
600 & 3 & 90 & 6136 \\
600 & 5 & 30 & 6682 \\
600 & 5 & 90 & 6454 \\
750 & 1 & 30 & 6581 \\
750 & 1 & 90 & 6719 \\
750 & 3 & 30 & 6738 \\
750 & 3 & 90 & 6974 \\
750 & 5 & 30 & 6772 \\
750 & 5 & 90 & 6707 \\
900 & 1 & 30 & 6860 \\
900 & 1 & 90 & 6438 \\
900 & 3 & 30 & 6715 \\
900 & 3 & 90 & 6637 \\
900 & 5 & 30 & 6813 \\
900 & 5 & 90 & - \\
\hline
\end{tabular}

1 Médias de suas repetições 
TABELA 17. Valores de F para poder calorifico superior do carvão de turfa.

Causa da variação

F

Temperatura final (A)

$119,94 * *$

Taxa de aquecimento

(B)

$0,30 \mathrm{~ns}$

Tempo de permanēncia (C)

$6,97 *$

Interação A x B

$1,28 \mathrm{~ns}$

Interação $\mathrm{A} \times \mathrm{C}$

$1,54 \mathrm{~ns}$

Interação B x C

$0,51 \mathrm{~ns}$

Coeficiente de variação (\%)

3,59

$\mathrm{ns}=$ não significativo

* = significativo ao nivel de $5 \%$ de probabilidade

** = significativo ao nivel de $1 \%$ de probabilidade 
TABELA 18. Comparação de médias de poder calorífico superior do carvão de turfa em função de cada fator testado na pirólise.

\begin{tabular}{|c|c|c|c|c|}
\hline Fatores & $\begin{array}{l}\text { Temperatura final } \\
\left({ }^{\circ}\right)\end{array}$ & Poder & $\begin{array}{r}\text { calorifico } \\
(\mathrm{kcal} / \mathrm{kg})\end{array}$ & superior \\
\hline \multirow{5}{*}{$\begin{array}{c}\text { Temperatura } \\
\text { final } \\
\left({ }^{\circ}\right)\end{array}$} & 300 & & 5147 & $\mathrm{~d}$ \\
\hline & 450 & & 5714 & $c$ \\
\hline & 600 & & 6536 & $b$ \\
\hline & 750 & & 6707 & $\mathrm{a}$ \\
\hline & 900 & & 6695 & $a b$ \\
\hline \multirow{3}{*}{$\begin{array}{l}\text { Taxa de } \\
\text { aquecimento } \\
\left({ }^{\mathrm{C} / \mathrm{min})}\right.\end{array}$} & 1 & & 6134 & $a$ \\
\hline & 3 & & 6158 & $a$ \\
\hline & 5 & & 6188 & $a$ \\
\hline \multirow{2}{*}{$\begin{array}{l}\text { Tempo de } \\
\text { permanência } \\
\text { (min) }\end{array}$} & 30 & & 6085 & $\mathrm{~b}$ \\
\hline & 90 & & 6235 & $a$ \\
\hline
\end{tabular}

Média geral do experimento

$616 \mathrm{C}$

As médias seguidas pela mesma letra não diferem entre si pelo teste de Waller-Duncan 


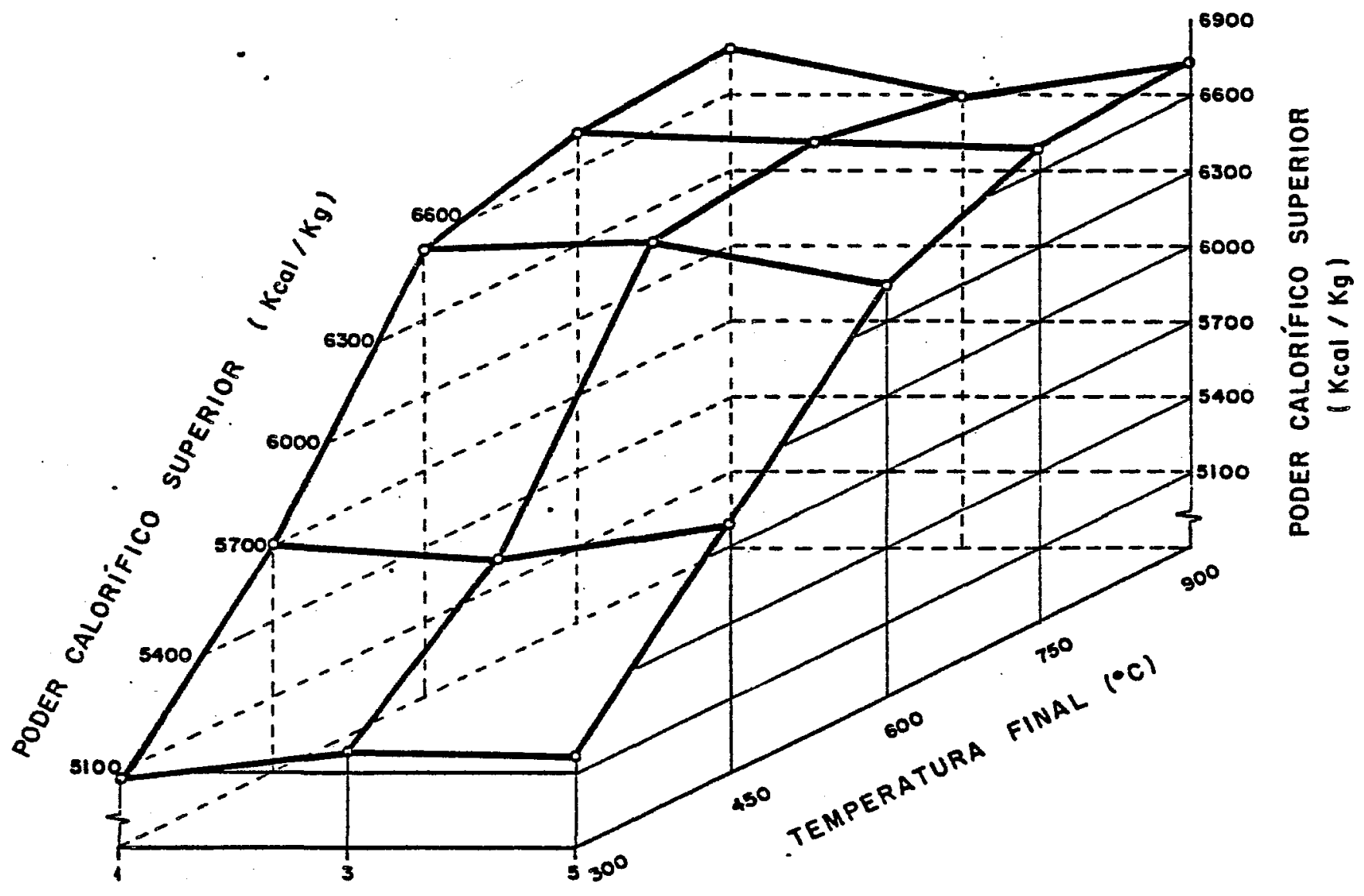

TAXA DE AOUECIMENTO

$\left({ }^{\circ} \mathrm{C} /\right.$ minuto $)$

FIGURA 9. Efeito da taxa de aquecimento e temperatura final no poder calorifico superior do carvão de turfa. 


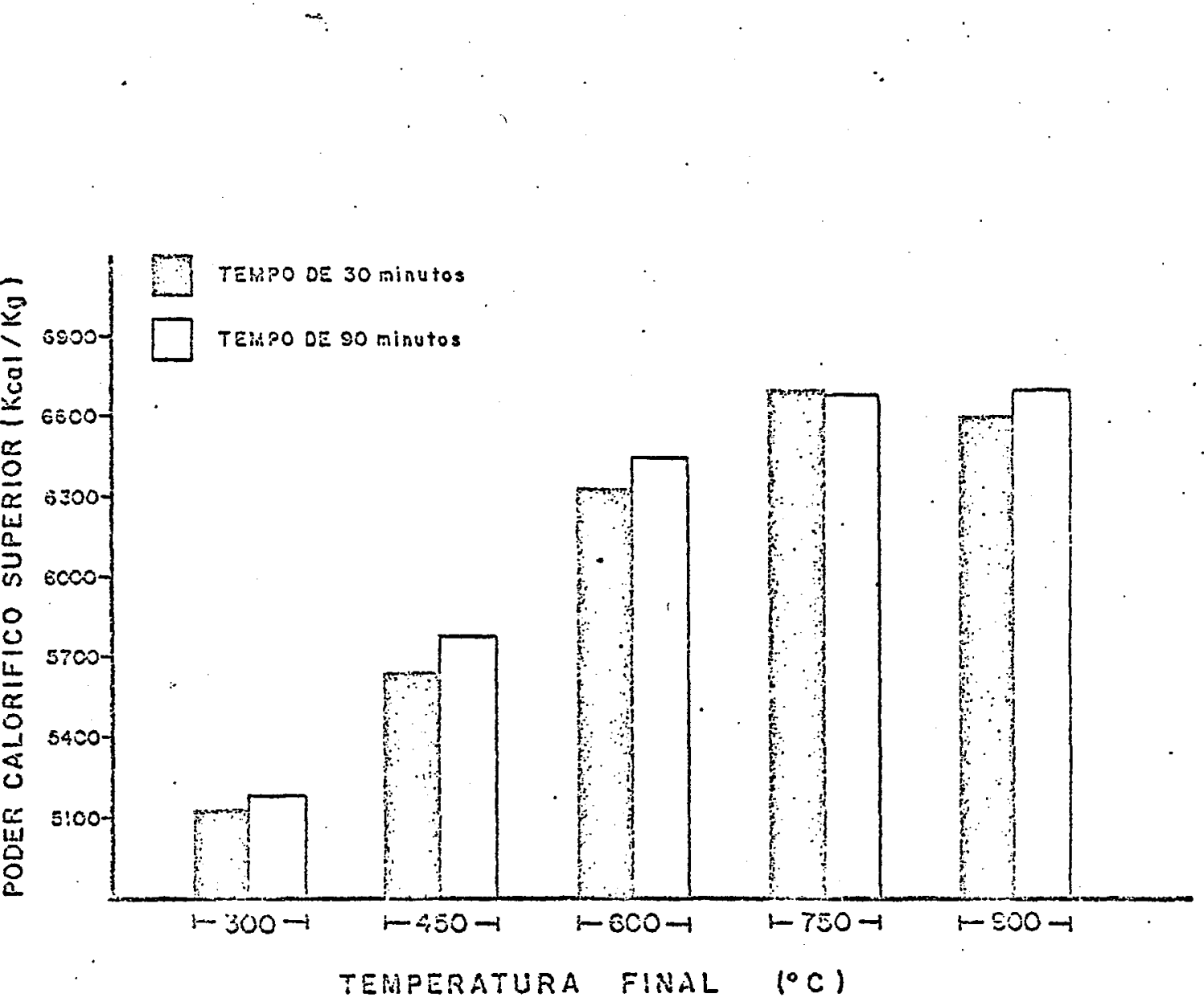

FIGURA 10. Efeito do tempo de permanência e temperatura final no poder calorífico superior do carvão.de turfa. 
A medida que elevou-se a temperatura, observa -se acréscimos nos valores do poder calorifico superior, sen do que nas temperaturas mais altas houve uma tendência de es tabilização.

Isto é compreensivel tendo em vista que o aumento na temperatura provoca maior concentração de carbono fixo e menor concentração no teor de matérias voláteis. Con firmando este comportamento foi observado que o poder calorí fico superior do carvão tem uma forte correlação positiva $(r=0,9012)$ com o teor de carbono fixo e uma negativa $(r=$ $-0,9371)$ com o teor de matérias voláteis.

o comportamento verificado no poder calorifico superior do carvão de turfạ está de acordo com averigua cões realizadas por FUCHSMAN (1980) para turfa e de COUTINHO (1984) e FARIA (1984) para madeira.

Por sua vez, o tempo de permanência na temperatura final influencia, positivamente, o poder calorifico superior do carvão.

Como era esperado e considerando os resultados médios do poder calorifico superior, observa-se que este è bem mais influenciado pela temperatura final do que pelos fatores taxa de aquecimento e tempo de permanência na temperatura final. 
No geral, o comportamento do poder calorifico superior do carvão de turfa assemelha-se ao verificado na lí. teratura tanto para turfa (FUCHSMAN, 1980), como pará madeiras (EARL, 1975; TROSSERO, 1981; COUTINHO, 1984 e FARIA, 1984).

Comparativamente aos dados de Keppeler e Holfamann ${ }^{1}$ citados por FUCHSMAN (1980) os resultados de poder calorifico superior foram ligeiramente inferiores. Isto pode ser explicado pelo alto teor de cinzas contido na turfa originalmente, que por conseguinte gerou um carvão com tambēm alto teor de cinzas, que atua como material inerte. Tan to é verdade, que o crescente aumento verificado no teor de cinzas, em função da elevação da temperatura, imprimiu um me nor gradiente de elevação no poder calorifico superior, em função de aumento naquele fator. Por outro lado, os valores médios do poder calorifico obtidos nos tratamentos com tempe ratura de $450^{\circ} \mathrm{C}$, estão de acordo com aqueles mencionados por SILVA \& BRITO (1987) para carvão de turfa com alto teor de cinzas e obtido em condições de pirōlise prōximas ao do presente estudo.

1 KEPPELER, G. \& HOLFFMANN, H. Brennstoff Chemie, 13:401-6, 1932 . 


\subsubsection{Análise imediata do carvão de turfa}

Os fatores temperatura final, taxa de aquecimento e tempo de permanência na temperatura final provocaram mudanças substanciais nos resultados da análise imediata do carvão de turfa, ou seja nós teores de materias voláteis, cinzas e carbono fixo.

Seus efeitos podem ser observados pelos resul tados médios da anālise imediata apresentados na Tabela 19 e pelos valores de $F$ obtidos nas análises de variāncia apresen tados na Tabela 20 .

Os resultados individuais globais, bem como as análises de variāncia são apresentados nas Tabelas :35 e de 37 a 39 do Apêndice.

As Figuras de 11 a 13 apresentam ilustrações sobre os efeitos dos fatores testados sobre a composição ime diata do carvão de turfa.

Quando os valores de F da Tabela 20 apresenta ram-se significativos para interação entre fatores, procedeu -se ao desdobramento dos valores médios dos parāmetros da composição imediata para melhor visualização e discussão dos resultados. Tais desdobramentos são mostrados nas Tabelas de 21 a 23 . 
TABELA 19. Resultados médios da análise imediata do carvão de turfal.

\begin{tabular}{|c|c|c|c|c|c|}
\hline $\begin{array}{c}\text { Temperatura } \\
\text { final } \\
\left({ }^{\circ} \mathrm{C}\right)\end{array}$ & $\begin{array}{l}\text { Taxa de } \\
\text { aqueci- } \\
\text { mento } \\
\left({ }^{\circ} \mathrm{C} / \mathrm{min}\right)\end{array}$ & $\begin{array}{c}\text { Tempo de } \\
\text { permanên } \\
\text { cia } \\
\text { (min) }\end{array}$ & $\begin{array}{c}\text { Teor de } \\
\text { matérias } \\
\text { voláteis } \\
\left(\frac{0}{0}\right)\end{array}$ & $\begin{array}{c}\text { Teor de } \\
\text { cinzas } \\
(\%)\end{array}$ & $\begin{array}{l}\text { Teor de } \\
\text { carbono } \\
\text { (\%) }\end{array}$ \\
\hline $\begin{array}{l}300 \\
300 \\
300 \\
300 \\
300 \\
300 \\
450 \\
450 \\
450 \\
450 \\
450 \\
450 \\
600 \\
600 \\
600 \\
600 \\
600 \\
600 \\
750 \\
750 \\
750 \\
750 \\
750 \\
750 \\
900 \\
900 \\
900 \\
900 \\
900 \\
900\end{array}$ & $\begin{array}{l}1 \\
1 \\
3 \\
3 \\
5 \\
5 \\
1 \\
1 \\
3 \\
3 \\
5 \\
5 \\
1 \\
1 \\
3 \\
3 \\
5 \\
5 \\
1 \\
1 \\
3 \\
3 \\
5 \\
5 \\
1 \\
1 \\
3 \\
3 \\
5 \\
5\end{array}$ & $\begin{array}{l}30 \\
90 \\
30 \\
90 \\
30 \\
90 \\
30 \\
90 \\
30 \\
90 \\
30 \\
90 \\
30 \\
90 \\
30 \\
90 \\
30 \\
90 \\
30 \\
90 \\
30 \\
90 \\
30 \\
90 \\
30 \\
90 \\
30 \\
90 \\
30 \\
90\end{array}$ & $\begin{array}{r}49,50 \\
45,29 \\
46,59 \\
46,67 \\
45,27 \\
45,00 \\
32,50 \\
25,26 \\
27,31 \\
26,61 \\
27,80 \\
23,53 \\
13,27 \\
12,04 \\
14,85 \\
13,99 \\
15,40 \\
14,21 \\
7,61 \\
7,74 \\
8,48 \\
7,11 \\
7,03 \\
6,82 \\
5,04 \\
3,74 \\
4,13 \\
3,60 \\
3,72 \\
3,30\end{array}$ & $\begin{array}{r}\ddots \\
20,41 \\
23,96 \\
23,35 \\
20,72 \\
22,22 \\
20,86 \\
23,09 \\
31,34 \\
30,13 \\
16,19 \\
24,13 \\
31,82 \\
37,05 \\
32,79 \\
26,92 \\
31,32 \\
30,94 \\
30,15 \\
39,65 \\
38,34 \\
39,04 \\
38,18 \\
35,51 \\
36,69 \\
39,59 \\
37,20 \\
40,28 \\
32,63 \\
34,67 \\
36,65\end{array}$ & $\begin{array}{l}30,08 \\
30,75 \\
30,05 \\
32,35 \\
32,50 \\
34,13 \\
44,41 \\
43,49 \\
42,53 \\
47,19 \\
48,06 \\
44,60 \\
49,67 \\
55,19 \\
58,23 \\
54,68 \\
53,65 \\
55,64 \\
52,74 \\
53,91 \\
52,47 \\
54,70 \\
59,45 \\
56,48 \\
55,57 \\
59,06 \\
55,58 \\
63,76 \\
61,60 \\
61,04\end{array}$ \\
\hline
\end{tabular}

1 Médias de duas repetições 
TABELA 20. Valores de $F$ para análise imediata do carvão de turfa.

\begin{tabular}{lrcc}
\hline Causa de variação & $\begin{array}{r}\text { Teor de } \\
\text { matérias } \\
\text { voláteis }\end{array}$ & $\begin{array}{c}\text { Teor de } \\
\text { cinzas }\end{array}$ & $\begin{array}{c}\text { Teor de } \\
\text { carbono } \\
\text { fixo }\end{array}$ \\
\hline Temperatura final (A) & $2441,86 *$ & $94,57 * *$ & $341,27 * *$ \\
Taxa de aquecimento (B) & $3,56 *$ & $4,15 *$ & $12,07 * *$ \\
Tempo de permanēncia (C) & $25,22 * *$ & $0,01 \mathrm{~ns}$ & $6,41 *$ \\
Interação A x B & $2,95 *$ & $1,63 \mathrm{~ns}$ & $1,29 \mathrm{~ns}$ \\
Interação A x C & $4,24 *$ & $3,46 *$ & $1,49 \mathrm{~ns}$ \\
Interação B x C & $3,95 *$ & $3,42 *$ & $3,76 *$ \\
\hline Coeficiente de variação (o) & $6,13$. & 7,51 & $4,23$. \\
\hline
\end{tabular}

$\mathrm{ns}=$ não significativo

* = significativo ao nivel de $5 \%$ de probabilidade

** = significativo ao nivel de $1 \%$ de probabilidade 


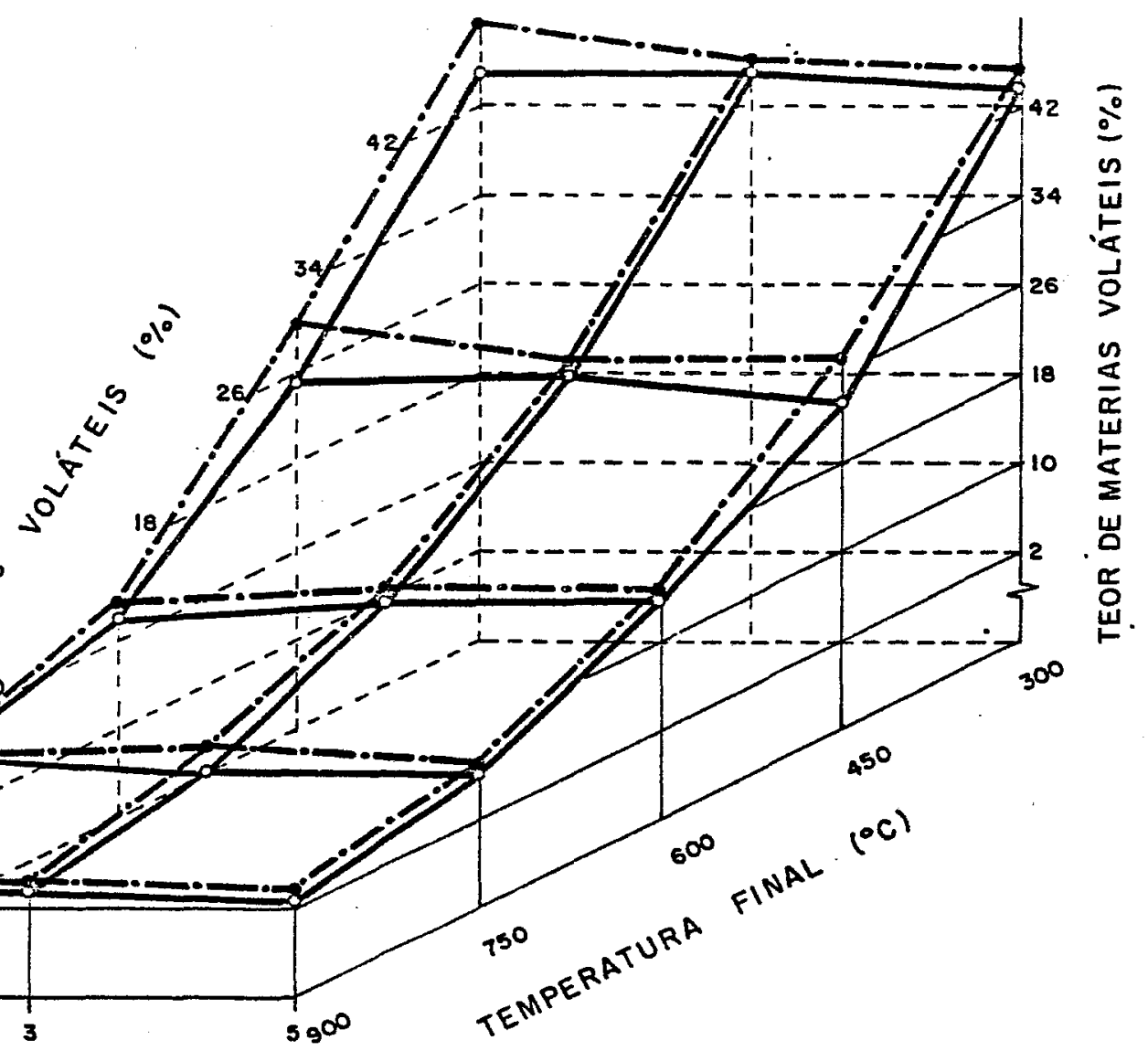

TAXA DE AQUECIMENTO

$\left({ }^{\circ} \mathrm{C} /\right.$ minuto )

FIGURA 11. Efeito da taxa de aquecimento, temperatura final e tempo de permanēncia no teor de matérias voláteis do carvão de turfa. 


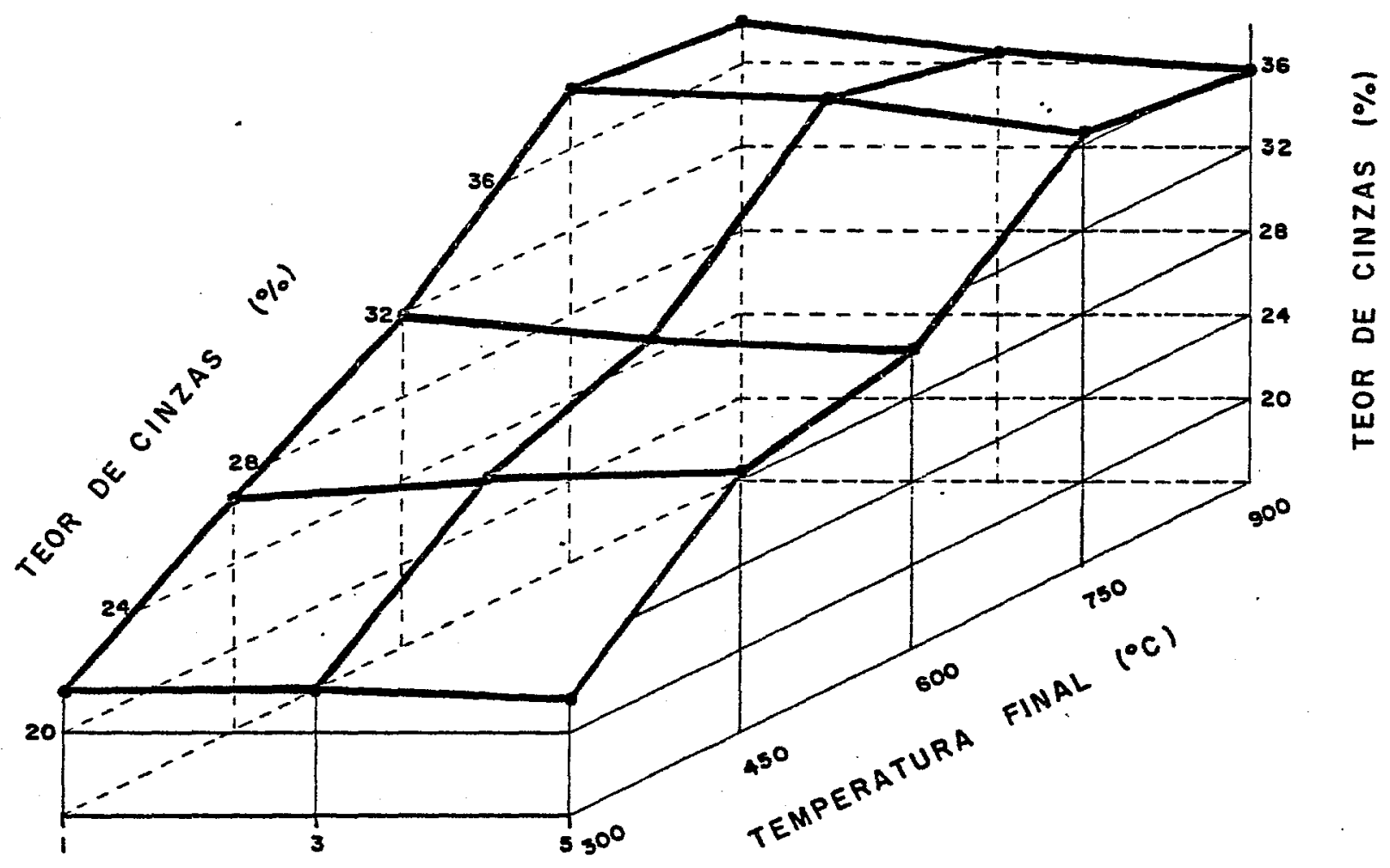

TAXA DE AQUECIMENTO

$\left({ }^{\circ} \mathrm{C} /\right.$ minuto $)$

FIGURA 12. Efeito da taxa de aquecimento e temperatura final no teor de cinzas do carvão de turfa. 


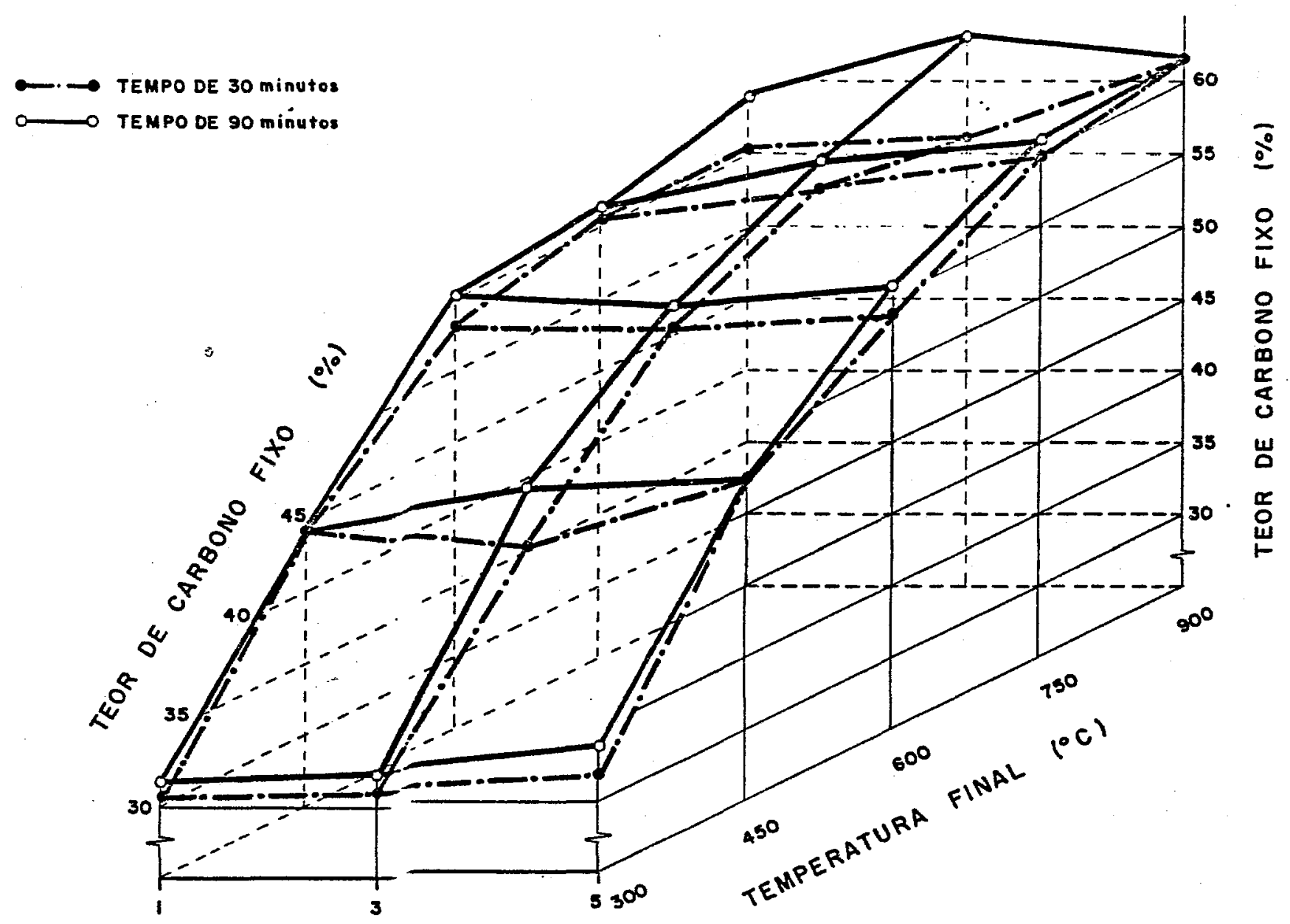

TAXA DE AQUF CIMENTO

(०C/minuto)

FIGURA 13. Efeito da taxa de aquecimento, temperatura final e tempo de permanência no teor de carbono fixo do carvão de turfa. 
TABELA 21. Comparação de médias do teor de matérias voláteis do carvão de turfa em função da temperatura final e da taxa de aquecimento.

\begin{tabular}{|c|c|c|c|c|c|}
\hline \multirow[t]{2}{*}{ Parâmetro. } & \multirow{2}{*}{$\begin{array}{l}\text { Temperatura } \\
\text { final } \\
\text { (o C) }\end{array}$} & \multicolumn{4}{|c|}{$\begin{array}{c}\text { Taxa de aquecimento } \\
\left({ }^{\circ} \mathrm{C} / \mathrm{min}\right)\end{array}$} \\
\hline & & 1 & & 2 & 3 \\
\hline \multirow{5}{*}{$\begin{array}{l}\text { Teor de } \\
\text { matérias } \\
\text { voláteis } \\
\quad(\%)\end{array}$} & 300 & 47,40 & $a A *$ & $46,63 \mathrm{aA}$ & $45,14 \mathrm{aB}$ \\
\hline & 450 & 28,88 & $\mathrm{bA}$ & $26,97 \mathrm{bA}$ & $25,66 \mathrm{bB}$ \\
\hline & 600 & 12,66 & $\mathrm{CB}$ & $14,42 \mathrm{CAB}$ & $14,81 \mathrm{cA}$ \\
\hline & 750 & 7,68 & $d A$ & $7,80 \mathrm{dA}$ & $6,93 \mathrm{dA}$ \\
\hline & 900 & 4,39 & $e A$ & 3,87 eA & $3,51 \mathrm{eA}$ \\
\hline
\end{tabular}

* As médias na coluna com mesma letra minúscula ou na linha com mesma letra maiúscula não diferem. entre si pelo teste de Waller-Duncan. 
TABELA 22. Comparação de médias do teor de matérias voláteis e de cinzas do carvão de turfa em função da tempe ratura final e tempo de permanència.

\begin{tabular}{|c|c|c|c|c|c|}
\hline \multirow[t]{2}{*}{ Parāmetro } & \multirow{2}{*}{$\begin{array}{c}\text { Temperatura } \\
\text { final } \\
\left({ }^{\circ} \mathrm{C}\right)\end{array}$} & \multicolumn{4}{|c|}{$\begin{array}{c}\begin{array}{c}\text { Tempo de permanência } \\
\text { (minutos) }\end{array} \\
\end{array}$} \\
\hline & & 30 & & 90 & \\
\hline \multirow{5}{*}{$\begin{array}{c}\text { Teor de matérias } \\
\text { voláteis (\%) }\end{array}$} & 300 & 47,12 & $a A *$ & 45,66 & $a A$ \\
\hline & 450 & 29,20 & $\mathrm{bA}$ & 25,13 & $\mathrm{bB}$ \\
\hline & 600 & 14,51 & $\mathrm{CA}$ & 13,41 & $\mathrm{CA}$ \\
\hline & 750 & 7,71 & $d A$ & 7,22 & $d A$ \\
\hline & 900 & 4,30 & eA & 3,55 & eA \\
\hline \multirow{5}{*}{$\begin{array}{c}\text { Teor de cinzas. } \\
(\%)\end{array}$} & 300 & 21,99 & $d A$ & 21,85 & $\mathrm{CA}$ \\
\hline & 450 & 25,78 & $C B$ & 29,78 & $\mathrm{bA}$ \\
\hline & 600 & 31,64 & $\mathrm{bA}$ & 31,42 & $\mathrm{bA}$ \\
\hline & 750 & 38,07 & $a A$ & 37,74 & $a A$ \\
\hline & 900 & 38,18 & $a A$ & 35,16 & $a B$ \\
\hline
\end{tabular}


TABELA 23. Comparação de médias de análise imediata do carvão de turfa em função da taxa de aquecimento e tempo de permanência.

\begin{tabular}{|c|c|c|c|}
\hline \multirow[t]{2}{*}{ Parâmetro } & \multirow{2}{*}{$\begin{array}{l}\text { Taxa de } \\
\text { aqueci- } \\
\text { mento } \\
\left({ }^{\circ} \mathrm{C} / \mathrm{min}\right)\end{array}$} & \multicolumn{2}{|c|}{$\begin{array}{c}\text { Tempo de permanência } \\
(\min )\end{array}$} \\
\hline & & 30 & 90 \\
\hline \multirow{3}{*}{$\begin{array}{l}\text { Teor de matérias } \\
\text { voláteis }(\%)\end{array}$} & 1 & 21,58 aA* & 18,81 aв \\
\hline & 3 & $20,28 \mathrm{bA}$ & $19,60 \mathrm{aA}$ \\
\hline & 5 & $19,85 \mathrm{cA}$ & 18,57 aA \\
\hline \multirow[t]{3}{*}{ Teor de cinzas $(\%)$} & 1 & 31,96 aA & 32,73 aA \\
\hline & 3 & 31,95 aA & $29,81 \mathrm{bA}$ \\
\hline & 5 & $29,50 \mathrm{bA}$ & $31,04 \mathrm{abA}$ \\
\hline \multirow[t]{3}{*}{ Teor de carbono fix } & \%) & $46,50 \mathrm{bB}$ & $48,48 \mathrm{bA}$ \\
\hline & 3 & $47,77 \mathrm{bB}$ & 50,54 aA \\
\hline & 5 & 51,05 aA & $50,38 \mathrm{aA}$ \\
\hline
\end{tabular}

* As médias na coluna com mesma letra minúscula ou na linha com mesma letra maiūscula não diferem entre si pelo teste de Waller-Duncan. 
Verifica-se que o teor de matërias. voläteis do carvão foi influenciado estatisticamente pela temperatura final, taxa de aquecimento e tempo de permanência, bem como pelas interações ocorridas entre estes fatores.

O decréscimo encontrado no teor de voláteis no carvão de turfa com a elevação da temperatura final está de acordo com observações feitas por CHUKANOV et alii (1962) para turfa e os resultados conseguidos por WENZI (1970), EARI (1975), MENDES et aIii (1982), OLIVEIRA et aIii (1982d) e ALMEIDA (1983) em carbonização de madeiras.

Isto é compreensivel tendo em vista que, o au mento de temperatura provoca a expansão dos gases e sua expulsão do interior da turfa durante sua pirólise.

Foi observada uma forte correlação positiva $(r=0,9812)$ entre o teor de matérias voláteis do carvão de turfa e o seu rendimento gravimētrico em carvão. Este rendị mento em carvão foi afetado de maneira inversa a variação na taxa de aquecimento. Por esta razão, observa-se, tambēm, um decréscimo no teor de matérias voláteis com o aumento da taxa de aquecimento (Figura 11 e Tabela 21).

Foi verificada uma correlação significativa e negativa entre o teor de matérias voláteis e o rendimento gravimétrico de voláteis condensáveis e não condensáveis. No 
item 4.2., através das Tabelas 5 e 8 , foi observado que o maior tempo de permanēncia, para uma determinada temperatura final, provoca umá maior eliminação de voláteis. Portanto, era esperado que o tempo de permanência exercesse influēncia de maneira inversa, como de fato verifica-se, sobre o teor de matérias voláteis no carvão de turfa.

Verifica-se tambēm, que para os materiais voláteis a temperatura final proporcionou efeito preponderante em relação aos outros fatores testados na pirólise da turfa.

Os resultados médios do teor de matérias voláteis do carvão, de certa forma, estão de acordo com aque les encontrados por FUCHSMAN (1980) que foram 28,15 e 17,50\%, respectivamente, nas temperaturas de 450 e $550^{\circ} \mathrm{C} \mathrm{com}$ turfa contendo $7,60 \%$ de umidade.

Quanto a cinza verifica-se que o seu teor foi estatisticamente, influenciado pela temperatura final e taxa de aquecimento e pelas interações ocorridas entre temperatura final e tempo de permanência e entre este com a taxa de aquecimento.

Presume-se que a quantidade real de cinzas contida originalmente na matéria prima vai permanecer a mesma encontrada: no produto sólido da pirólise. Portanto, a cinza torna-se uma matéria inerte na composição da tur 
fa.

Por outro lado, o tratamento térmico provoca a eliminação de voláteis com a consequente perda de massá por parte da turfa, aumentando-se a quantidade relativa de cinzas no, carvão obtido. Este aumento relativo de cinzas na composição do carvão é diretamente proporcional ao teor contido originalmente na matéria prima (Tabela 4) e o rendimento gravimétrico em voláteis.

o maior conteúdo relativo de cinzas no carvão foi encontrado nas temperaturas finais de $750 \mathrm{e} 900^{\circ} \mathrm{C}$, que por sua vez proporcionaram rendimento gravimētrico mais elevado em voláteis condensáveis e não condensáveis.

Verifica-se que é nitidamente destacado o efeito de temperatura final sob os demais fatores testados na termodegradação de turfa quanto ao teor de cinzas no carvão.

Em relação ao teor de carbono fixo, estatisti camente, ele foi influenciado pelos fatores testados na pirólise, bem como pela interação ocorrida entre a taxa de aquecimento e o tempo de permanência na temperatura final.

o aumento do teor de carbono fixo do carvão provocado pelo aumento da temperatura final até próximo de $\cdot 700^{\circ} \mathrm{C}$ já é bastante conhecido, mormente para carbonização de madeira, e tem sido mencionado por vârios autores como WENZL 
(1970), PETROFF \& DOAT (1978) e FARIA (1984), trabalhando com várias espécies florestais e por JUVILLAR (1980), MENDES et alii (1982), OLIVEIRA et alii (1982b) e OLIVEIRA et alii (1982d), trabalhando com espécies de Eucalyptus. Para a degradação térmica da turfa este comportamento foi observado por CHUKANOV et alii (1982) e FUCHSMAN (1980).

Na faixa de temperatura entre 300 e $600^{\circ} \mathrm{C}$, 0 ganho conseguido com 0 aumento no teor de carbono fixo no carvão de turfa foi bem destacado; entretanto, o ganho obser vado nas temperaturas acima de $600^{\circ} \mathrm{C}$ foi relativamente peque no.

A Tabela 23 mostra que houve um ligeiro ganho no teor de carbono fixo do carvão com a elevação da taxa de aquecimento e também com o aumento do tempo de permanência final.

Isto é compreensivel, pois, a medida que proporcionou-se uma : pirólise mais rápida, com maior taxa de aquecimento, houve uma tendência de liberar e expulsar os produtos voláteis da turfa mais abruptamente. Como consequência, tornou-se o produto sólido mais concentrado em carbono fixo. Por sua vez, é evidente que quanto maior for 0 tempo de permanēncia numa determinada temperatura final, maior vai ser a oportunidade para liberar mais voláteis, redundando num maịor teor de carbono fixo no produto sólido fi 
nal. Tal fato é ainda evidenciado pelo coeficiente de corre lação igual a 0,9387 verificado entre o teor de carbono fixo do carvão e o rendimento gravimétrico de voláteis condensáveis e não condensáveis. Este fato é ainda realçado pela forte correlação negativa ocorrida entre o teor de carbono fixo e o teor de matérias voláteis do carvão de turfa.

Com base nos valores de $F$ da análise de variância e pelas médias do teor de carbono fixo do carvão encontradas nas Tabelas 21 e 22, depreende-se que este parāmetro foi influenciado com maior evidência pela temperatura fi nál do que pelos demais fatores usados na ipirólise dá turfa. 


\section{CONCLUSÕES}

Com base nos resultados e considerando :o material e as condições empregadas neste estudo, pode concluir-se que:

a. a turfa utilizada è do tipo energētica;

b. os rendimentos dos produtos da pirólise de turfa e as características de seu carvão são influenciados pelos fatores de tratamento empregados;

c. a temperatura final foi o fator que exerceu maior efeito no rendimento gravimétrico dos produtos da pirólise de turfa; bem como nas características do seu carvão;

d. o rendimento gravimétrico de carvão sofreu ređuções enquanto os volāteis condensáveis e não-condensáveis sofre- 
ram acréscimos quanto maior foi a temperatura final da pi rólise de turfa;

e. nas temperaturas mais baixas de pirólise, observou-se que - rendimento gravimētrico de carvão de turfa diminuiu e de voláteis aumentou com a el evação da taxa de aquecimento e do tempo de permanência na temperatura final;

f. a turfa, originalmente classificada acima de $10 \mathrm{~mm}$, sofreu redução na granulometria a níveis de 40 a $45 \%$ apōs sua pirólise, sendo que o fator que mais contribuiu para este comportamento foi a taxa de aquecimento;

g: as densidades verdadeira e aparente do carvão aumentaram quanto maior foi a temperatura final da pirólise de turfa;

h. dentre os parâmetros analisados, a porosidade foi a que apresentou-se menos influenciada pelos fatores testados;

i. quanto maior foi a temperatura final da pirólise maior foi o valor do poder calorífico superior do carvão de tur fa atè a temperatura de $750^{\circ} \mathrm{C}$, acima desta houve tendència de estabilização;

j. quanto maior foi a temperatura final e o tempo de permanência da pirólise reduziu-se o teor de matērias volāteis e aumentou-se os teores de cinza e de carbono fixo do carvão de turfa; 
k o poder calorífico superior do carvão de turfa foi correlacionado, positivamente com a produção de voláteis duran te a pirólise e com o teor de carbono fixo e, negativamen com o rendimento gravimétrico en carvão de turfa e o seu teor de matérias voláteis; e,

1. è possivel obter-se carvão de turfa com diferentes características e, portanto, com possibilidades de múltiplas aplicações. 


\section{REFERENCIAS BIBLIOGRÁFICAS}

ALMEIDA, J.M. Efeito da temperatura sobre rendimento e propriedade dos produtos de carbonização de Eucalyptus grandis W. Hill ex Maiden. Viçosa; 1983. 40 p. (Tese - Mes trado - UFV).

ANSON, D.; HAZARD, H.R.; MURIN, J.M. \& HONEA, F.I. The potential for use of peat blends with coal for eletric power generation. In: AMERICAN SOCIETY OF MECHANICAL ENGINEERS - ASME/IEEF. Power Generation Conference. 4-8 october, 1981. $11 \mathrm{p}$.

ASSOCIAÇÃO BRASILEIRA DE NORMAS TECNICAS. ABNT. Normas Eéç nicas. NBR - No 8112 de 1983. Brasilia, 1983. 
ASSOCIAÇÃO BRASILEIRA DE NORMAS TECNICAS. ABNT. Normas téć. nicas NBR - № 8633 de 1985. Brasilia, 1985.

BEL'KEVICH, P.I. et alii. Thermal decomposition of individual components of seed peat. Ser. Khimyia Navuk (ㅁ) : 53-6, 1971. Apud Chemical Abstract, 76. $(8): 114$, 1972 .

BERTHELOT, C. \& KLING, M.A. La tourbe: exploitation et conditionnement, Ed. Dunop. Paris, 1943. 219 p.

BRASIL, MINISTERIO DAS MINAS E ENERGIA - Balanço energético nacional. Brasilia, 1986. 148 p.

BRITO, J.O. Uso energético da madeira. Piracicaba. ESALQ/ USP, 1978. 40p. (datilografado).

BRITO, J.O. \& BARRICHELO, L.E.G. Aspectos técnicos da utili zação da madeira e carvão vegetal como combustíveis. In: SEMINÁRIO DE ABASTECIMENTO ENERGETICO INDUSTRIAL COM RECURSOS FLORESTAIS. Anais, São Paulo, 1982. p.101-36.

BRITO, J.O. \& BARRICHELO, L.E.G. Comportamentos isolados de lignina e da celulose da madeira frente à carbönização. Circular Técnica. IPEF, Piracicaba, (28):1-4, 1977. 
CENCIG, M.O.; CENCIG, E.G.S.; SCHUCHARDT, U.; LUENGO, C.A. Insumos químicos a partir de hidrōlise do carvão. Energia Fontes Alternativas, $\underline{5}(24): 24-42,1983$.

CHRISTIASSON, B. Low temperature carbonization of peat and constituints. Acta Polytech. Chemi. Ser. $\underline{3}(6): 7-128$, 1953. Apud Chemical Abstract, $\underline{48}(11): 5080$ d, 1954.

CHUKANOV, Z.I.; KASHURICHEV, A.P. \& STOMANS, Ya.A. Effect of composition and of increase in yield of volatile products in fuel pyrolisis at high heating rates. Doch. Akad. Nauk. 555R. 143: 162-5, 1962. Apud Chemical Abstracts, $\underline{57}(\mathrm{~F}): 1200 \mathrm{~h}, 1962$.

COHEN, A.D. Obtaining more precise description of peats by use of oriented microtome sections. In: JARRET, P.M. Testing of Peats and Organic Soils, ASTM 820. New York, American Society for Testing and Materials, 1983. p. 37-51 .

CONCEIÇÃO, P.C. Tecnologia Outokumpu de processamento e uti zação de turfas. Energia Fontes Alternativas $\underline{4}(20)$ : 7281,1982 . 
COUTINHO, A.R. Qualidade do carvão vegetal correlacionada as caracteristicas da madeira de E. saligna e temperatura de carbonização. Piracicaba, 1984. 76 p. (Tese - Mestrado, ESALQ/USP) .

EARL, D.E. Forest energy and economic development, oxford, Claredon Press. 1975. 128 p.

FARIA, W.L.F. A jurema-preta (Mimosa hostilis Benth.) como fonte energética do semi-árido do Nordeste - Carvão. Curitiba, 1984. 113 p. (Tese - Mestrado - UFPr).

FARNHAM, R.S. Potential of peat for fuel. University of Minnesota, 1974. 29 p.

FUCHSMAN, C. Peat Industrial, Chemistry and Technology. New York, Academic Press, 1980. 278 p.

GOMES, P.A. \& OLIVEIRA, J.B. Teoria da carbonização da madeira. In: FUNDAÇÃO CENTRO TECNOLÓGICO DE MINAS GERAIS Uso da madeira para fins energéticos. Belo Horizonte, 1980. p. 27-42.

GOODWIN, E. A turfa no Brasil. Energia Fontes Alternativas. $\underline{5}(25 / 26): 7-8,1983$.

HARRIS, A.C. Charcoal production. In: WORLD FORESTRY CONGRESS, 8 , Jakarta, 1978. 15 p. (mimeografado) 
HINRICKSEN, D. Peat power: black to the bogs. Ambio, 10(5), 1981.

JAAKKO POYRY ENGENHARIA. Turfa uma alternativa enærgëtica, econōmica e regional. Energia Fontes Alternativas, $\underline{5}$ $(25 / 26): 9-14,1983$.

JUVILLAR, J.B. Carvão-vegetal, matēria prima energētica. In dústria e Produtividade, Rio de Janeiro (137) 23-6, jan/ fev, 1980 .

KEYS, D. Effect of peat type and decomposition on the calorific value of some New Brunswick peats. In: JARRETT, P.M. Testing and Organic Soils, ASTM STP 820. New York, American Society for Testing and Materials, 1983. p. $111-21$.

KIEHL, E.J. Fertilizantes orgānicos. São Paulo, Agronōmica Ceres, 1985. 492 p.

KUMOTo, E.T.; CONSTANzo Jr., J. \& MONTICEII, J.J. Carvão, turfa e rochas oleígenas. In: Companhia Energética de São Paulo, CESP, 1985. 58 p. (Série Pesquisa e Desenvol vimento, 14).

LARBALETRIER, A. La tourbe et les tourbēres. Paris, Masson et Cie. s.d. 189 p. 
LEMASTER, G.S.; BARTELLI, L.J. \& SMITH, M.R.

Characterization of Organic soils as energy sources. In: JARRETT, P.M. Testing of Peats and Organic Soils, ASTM STP 820. New York, American Society for Testing and Materials, 1983. p. 122-37.

LEPPA, K. Availability and utilization of peat and lignite as boiler fuel. TAPPI Anual Meeting, 1981. Proceedings, Atlanta, 1981. p. 339-41.

MARTINO, E.S. \& KURTH, G.M. Turfa - um combustivel a espera de utilização. Energia Fontes Alternativas 4. (20): 64$-71,1982$.

MATTAR, H. \& DELAZARO, W. Peat as an energy alternative in the State of São Paulo, Brasil. In: Symposium Papers of as an Energy Alternative, 1980, Institute of Gas Technology, Arlington, 1980.

MENDES, M.G.; GOMES, P.A. \& OLIVEIRA, J.B. Propriedades e controle de qualidade do carvão vegetal. In: FUNDAÇ̃̃o CENTRO TECNOLOGICO DE MINAS GERAIS. Produção e utilização do carvão vegetal. Belo Horizonte, 1982. p. 75-90.

OKAGAWA, H. Lavra experimental de turfa no rio Mogi-Guaçu. In: SEMINÁRIO SOBRE TURFA: PROSPECÇÃO, PRODUÇÃO E UCOS. São Paulo, 1985. Anais. São Paulo, Companhia Energética de são Paulo, 1985. p. 49-57. 
OLIVEIRA, L.T. \& ALMEIDA, M.R. Avaliação de carvão vegetal. In: FUNDAÇÃO CENTRO TECNOLOGICO DE MINAS GERAIS. Uso da madeira para fins energéticos. Belo Horizonte, 1980. p. 45-53.

OLIVEIRA; J.B.; GOMES, P.A. \& ALMEIDA, M.R. Cäracterização e otimização do processo de fabricação de carvão vegetal em fornos de alvenaria. In: FUNDAÇÃo CENTRO TECNOLÓGICO DE MINAS GERAIS. Carvão vegetal. Belo Horizonte, 1982a. p. 63-102.

OLIVEIRA, J.B.; GOMES, P.A. \& ALMEIDA, M.R. Estudos prelimi nares de normalização de testes de controle de qualidade do carvão vegetal. In: FunDAÇÃo CENTRO TECNOLÓGICO DE MI NAS GERAIS. Carvão Vegetal. Belo Horizonte, 1982b. p. $7-38$.

OLIVEIRA, J.B.; GOMES; P.A. \& ALMEIDA, M.R. Propriedades do carvão vegetal. In: FUNDAÇÃo CENTRO TECNOLÓGICO DE MINAS GERAIS. Carvão Vegetal. Belo Horizonte, 1982c. p. 3962 .

OLIVEIRA, J.B.; VIVACQUA Filho, A.; MENDES, M.G.`\& GOMES, P. A. Produção de carvão vegetal - aspectos técnicos. In: FUNDAÇÃO CENTRO TECNOLÓGICO DE MINAS GERAIS. Produção e Utilização de Carvão Vegetal. Belo Horizonte, 1982d. p. $59-74$. 
PETROFF, G. \& DOAT, J. Pirolise dés bois tropicaux: influencia de la composition chimique des bois sur les produits de destillation. Bois et Forets de Tropiques, Nogent-sur Marne, (117): 51-64, jan/fev. 1978.

PUNWANI, D.V. Peat as an energy alternative: $\ddot{n}$ overview. In: PEAT as an Energy Alternative. Arlington, Institute of Gas Technology, 1980a, 35 p.

PUNWANI, D.V. Synthetic fuels from peats. In: INTERNATIONAL PEAT CONGRESS, Duluth, August $17-23,1980 \mathrm{~b}$. p. 49-81 .

PUNWANI, D.V. \& RADER, A.M. Gas from peat: a good source of heat. Hidrocarbon Processing, :107-113, 1978.

RAMALHO, A.M. Carvões vegetais para gasogênios. Lisboa, Mi nistério da Economia. 1943. 110 p.

RODRIGUES, E.C. Solução energética. 2 ed. São Paulo, Editora Unidas, 1983. 361 p.

SHAFIZADEH, F.; SARKANEN, K.V. \& TILLMAN, D.A. Thermal uses and properties of carbohidrates and lignins. "New York, Academic Press, 1976. 320 p. 
SHAPATINA, E.A.; KASHURICHEV, A.P. \& KOUVAZINA, L.A. Thermal decomposition of peat and shale be heating with a sclid heat carrier. Energotexlud. Ispol'zovanie Topliva, Akad. Nank. S.S.S.R., Energt. Inst. in G.M. Krshizhanovg kogo, $\underline{1}: 171-201,1960$. Apud. Chemical Abstract, 55(7): $6823 b, 1961$.

SILVA, D.A. \& BRITO, J.O. Estudo comparativo da carbonização de três origens de turfas em relação a madeira de Eucalyptus grandis.: IPEF, Piracicaba (36) ago. 1987. (no prelo)

SILVA, J.C. Endocarpos de babaçu (Orbignya spp. Mart.) e de macaúba (Acrocomia sclerocarpa Mat.) comparados à madeira de Eucalyptus grandis W. Hill Ex. Maiden para a produção de carvão vegetal. Piracicaba, 1986. 112 p. (Tese Mestrado - ESALQ/USP) .

SILVA, O. A turfa agrícola no Brasil - Aproveitamento, produção e mercado real e potencial. In: SEMINÂRIO SOBRE TURFA: Prospeç̧̃̃o, Produção e Usos. São Paulo, 1985. Anais, São Paulo, Companhia Energética de São Paulo, 1985. p. $95-110$. 
SUSCZYNSKI, E.F. Turfa, o novo combustivel nacional. Energia Fontes Alternativas 4(2): 6-61, 1981.

TRONT, G. Pilot - plant peat cartonization design of industrial furnaces. Torfa 3 (2): 23-31, 1958. Apud. Chemicạl Abstract, 53, 3658c, 10 jan., 25 fev., 1959.

TROSSERO, M.A. Analisis de parametros de pirolisis de biomassa. Buenos Aires, Instituto Nacional de Tecnologia In dustrial, 1981. $14 \mathrm{p}$.

VALENTE, O.F.; ALMEIDA, J.M.; VITAL, B.R. \& DELLA LÚCIA, R. M. Efeito da temperatura de carbonização nos rendimentos e propriedades do carvão vegetal produzido. Revista Árvo re, Viçosa, $\underline{9}(1): 28-39,1985$.

WENZL, H.F.J. The chemical technology of wood. New York, Academic Press, 1970. 692 p.

ZHUKOV, V.R.; GRECHKO, K. \& TSERLYUKEVICH, Ya. An investigation of the thermal properties of peat wax and some its components. Khimiya Tverdogo Topliva, 14(4):85$-90,1980$. 
.105.

A P E N D I C E 
TABELA 24. Resultados de rendimento gravimétrico dos produtos da pirólise da turfa.

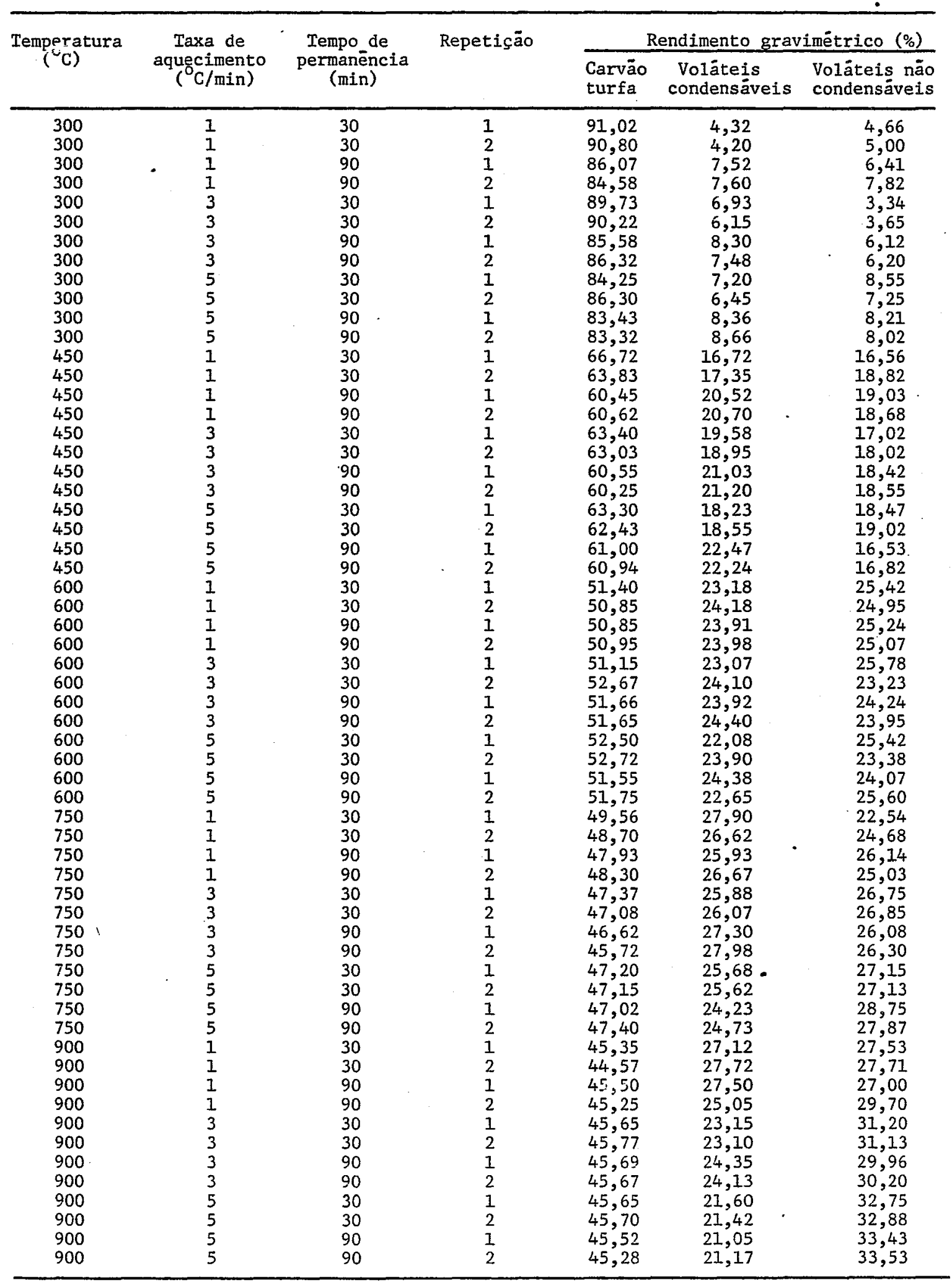


TABELA 25. Análise de variância para rendimento gravimétrico em carvão de turfa.

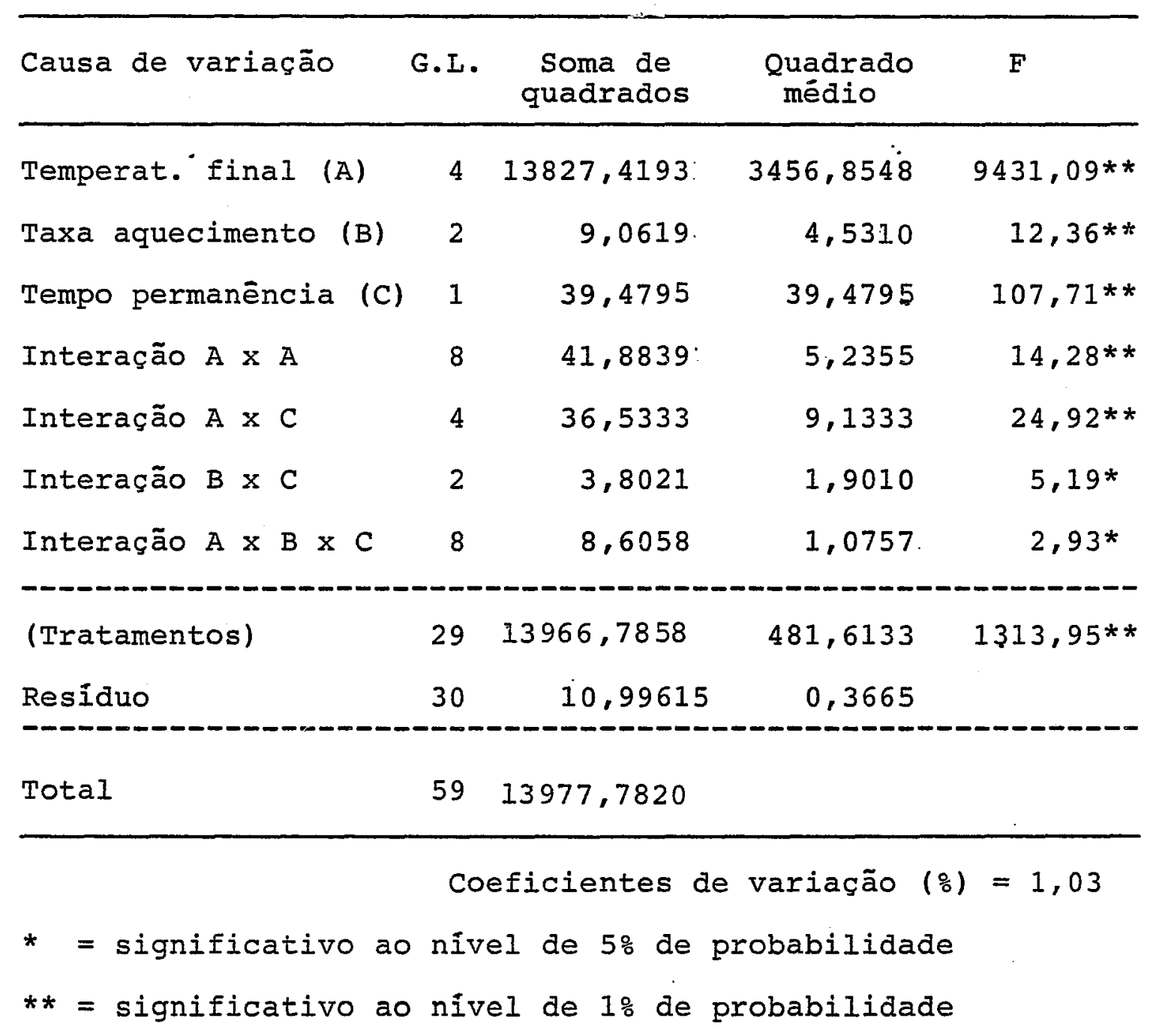


TABELA 26. Análise de variância para rendimento gravimētrico de volāteis condensāveis.

\begin{tabular}{|c|c|c|c|c|}
\hline Causa de variação & G.I. & $\begin{array}{l}\text { Soma de } \\
\text { quadrados }\end{array}$ & $\begin{array}{c}\text { Quadrado } \\
\text { médio }\end{array}$ & $F$ \\
\hline Temperat. final (A) & 4 & 2859,3903 & $714,8483^{\circ}$ & $2046,17 * *$ \\
\hline Taxa aquecimento $(B)$ & 2 & 9,9728 & 4,9864 & $14,27 * *$ \\
\hline Tempo permanência (C) & 1 & 17,5176 & $17,5176:$ & $50,14 * *$ \\
\hline Interação $A \times \mathrm{B}$ & 8 & 73,1527 & 9,1441 & $26,17 * *$ \\
\hline Interação $A \times C$ & 4 & 26,0007 & 6,5002 & $18,61 * *$ \\
\hline Interação B x C & 2 & 0,4151 & 0,2076 & $0,59 \mathrm{~ns}$ \\
\hline Interação A $x \mathrm{~B} \times \mathrm{C}$ & 8 & $11,9612:$ & 1,4951 & $4,28 *$ \\
\hline (Tratamentos) & 29 & 2998,4133 & 103,3936 & $295,95 * *$ \\
\hline Residuo & 30 & 10,4808 & 0,3494 & \\
\hline
\end{tabular}

Total

$59 \quad 3008,8941$

Coeficiente de variação $(\%)=2,94$

ns = não significativo

* = significativo ao nivel de 5\% de probabilidade ** = significativo ao nivel de $1 \%$ de probabilidade 
TABELA 27. Análise de variāncia para rendimento gravimétrico em voláteis não condensáveis.

\begin{tabular}{|c|c|c|c|c|}
\hline Causa de variação & G.L. & $\begin{array}{l}\text { Soma de } \\
\text { quadrados }\end{array}$ & $\begin{array}{l}\text { Quadrado } \\
\text { médio }\end{array}$ & F \\
\hline Temperat. final (A) & 4 & 4311,0706 & $1077,767^{\circ}$ & $1703,27 * *$ \\
\hline Taxa aquecimento (B) & 2 & 36,9306 & 18,4653 & $29,18 * *$ \\
\hline Tempo permanência (C) & 1 & 4,3470 & 4,3470 & $6,87 *$ \\
\hline Interação $\mathrm{A} \times \mathrm{B}$ & 8 & 59,2793 & 7,4099 & $11,71 * *$ \\
\hline Interação $\mathrm{A} \times \mathrm{C}$ & 4 & 6,7228 & 1,680 & $2,66 \mathrm{~ns}$ \\
\hline Interação $B \times C$ & 2 & 3,6573 & 1,8288 & $\dot{2}, 89 \mathrm{~ns}$ \\
\hline Interação $A \times B \times C$ & 8 & 12,3815 & 1,5477 & $2,45 *$ \\
\hline (Tratamentos) & 29 & 4434,3891 & 152,9000 & $241,65 * *$ \\
\hline Residuo & 30 & 18,9829 & 0,6327 & \\
\hline
\end{tabular}

Total

$59 \quad 4453,3720$

Coeficiente de variação $(\%)=3,76$

ns = não significativo

* = significativo ao nível de 5\% de probabilidade ** = significativo ao nivel de $1 \%$ de probabilidade 
TABELA 28. Granulometria da turfa.

Repetição

\% acima de $10 \mathrm{~mm}$

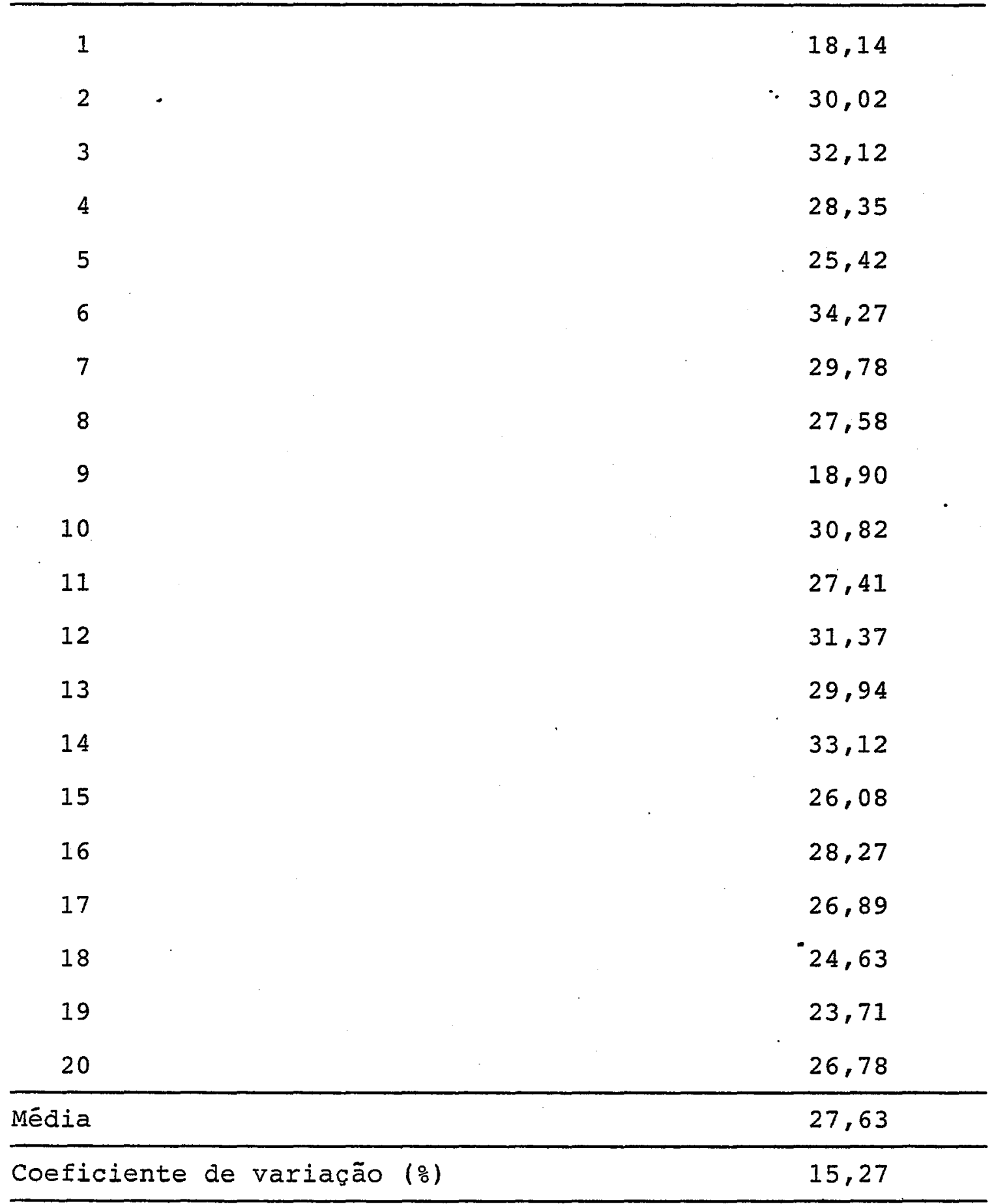


TABEIA 29. Resultados de granulometria do carvão de turfa e taxa de redução granulométrica.

\begin{tabular}{|c|c|c|c|c|c|}
\hline $\begin{array}{l}\text { Temperatura } \\
\text { final } \\
\quad\left({ }^{\circ} \mathrm{C}\right)\end{array}$ & $\begin{array}{c}\text { Taxa de } \\
\text { aquecimento } \\
\left({ }^{\circ} \mathrm{C} / \mathrm{min}\right)\end{array}$ & $\begin{array}{l}\text { Tempo na } \\
\text { temperatura } \\
\text { final } \\
\text { (min) }\end{array}$ & Repetição & $\begin{array}{l}\text { Granulometria } \\
(\%>10 \mathrm{~mm})\end{array}$ & $\begin{array}{c}\text { Taxa de reduçāo } \\
\text { granulométrica } \\
(\%)\end{array}$ \\
\hline $\begin{array}{l}300 \\
300 \\
300 \\
300 \\
300 \\
300 \\
300 \\
300 \\
300 \\
300 \\
300 \\
300 \\
450 \\
450 \\
450 \\
450 \\
450 \\
450 \\
450 \\
450 \\
450 \\
450 \\
450 \\
459 \\
600 \\
600 \\
600 \\
600 \\
600 \\
600 \\
600 \\
600 \\
600 \\
600 \\
600 \\
600 \\
750 \\
750 \\
750 \\
750 \\
750 \\
750 \\
750 \\
750 \\
750 \\
750 \\
750 \\
750 \\
900 \\
900 \\
900 \\
900 \\
900 \\
900 \\
900 \\
900 \\
900 \\
900 \\
900 \\
900\end{array}$ & $\begin{array}{c}1 \\
1 \\
1 \\
1 \\
1 \\
3 \\
3 \\
3 \\
3 \\
5 \\
5 \\
5 \\
5 \\
5 \\
1 \\
1 \\
1 \\
1 \\
1 \\
3 \\
3 \\
3 \\
3 \\
5 \\
5 \\
5 \\
5 \\
1 \\
1 \\
1 \\
1 \\
3 \\
3 \\
3 \\
3 \\
5 \\
5 \\
5 \\
5 \\
1 \\
1 \\
1 \\
1 \\
3 \\
3 \\
3 \\
3 \\
5 \\
5 \\
5 \\
5 \\
1 \\
1 \\
1 \\
7 \\
3 \\
3 \\
3 \\
3 \\
5 \\
5 \\
5 \\
5 \\
\end{array}$ & $\begin{array}{l}30 \\
30 \\
90 \\
90 \\
30 \\
30 \\
90 \\
90 \\
30 \\
30 \\
90 \\
90 \\
30 \\
30 \\
90 \\
90 \\
30 \\
30 \\
90 \\
90 \\
30 \\
30 \\
90 \\
90 \\
30 \\
30 \\
90 \\
90 \\
30 \\
90 \\
90 \\
90 \\
30 \\
30 \\
90 \\
90 \\
30 \\
30 \\
90 \\
90 \\
30 \\
30 \\
90 \\
90 \\
30 \\
30 \\
90 \\
90 \\
30 \\
30 \\
90 \\
90 \\
30 \\
30 \\
90 \\
90 \\
30 \\
30 \\
90 \\
90\end{array}$ & $\begin{array}{l}1 \\
2 \\
1 \\
2 \\
1 \\
2 \\
1 \\
2 \\
1 \\
2 \\
1 \\
2 \\
1 \\
2 \\
1 \\
2 \\
1 \\
2 \\
1 \\
2 \\
1 \\
2 \\
1 \\
2 \\
1 \\
2 \\
1 \\
2 \\
1 \\
2 \\
1 \\
2 \\
1 \\
2 \\
1 \\
2 \\
1 \\
2 \\
1 \\
2 \\
1 \\
2 \\
1 \\
2 \\
1 \\
2 \\
1 \\
2 \\
1 \\
2 \\
1 \\
2 \\
1 \\
2 \\
1 \\
2 \\
1 \\
2 \\
1 \\
2 \\
\end{array}$ & $\begin{array}{r}11,29 \\
15,37 \\
13,25 \\
9,06 \\
17,83 \\
13,81 \\
23,81 \\
15,33 \\
23,66 \\
21,59 \\
22,62 \\
22 \\
23,66 \\
24,53 \\
17,11 \\
11,17 \\
12,81 \\
8,88 \\
16,14 \\
15,19 \\
16,03 \\
11,07 \\
11,39 \\
17,39 \\
12,18 \\
11,66 \\
8,89 \\
11,68 \\
14,73 \\
13,95 \\
13,16 \\
16,57 \\
19,19 \\
19,\end{array}$ & $\begin{array}{l}59,05 \\
44,25 \\
51,94 \\
67,14 \\
35,33 \\
13,63 \\
44,40 \\
14,18 \\
21,69 \\
17,95 \\
14,18 \\
11,03 \\
37,93 \\
59,48 \\
53,53 \\
67,79 \\
41,45 \\
44,90 \\
39,11 \\
59,84 \\
36,92 \\
55,82 \\
57,70 \\
67,75 \\
57,63 \\
46,57 \\
49,40 \\
52,26 \\
39,89 \\
30,39 \\
45,59 \\
27,27 \\
30,61 \\
42,98 \\
26,69 \\
30,28 \\
53,60 \\
66,52 \\
54,84 \\
62,56 \\
51,03 \\
46,89 \\
46,53 \\
55,20 \\
33,00 \\
28,90 \\
37,21 \\
26,73 \\
55,02 \\
46,28 \\
65,54 \\
57,88 \\
26,58 \\
46,46 \\
40,76 \\
34,31 \\
31,91 \\
26,30 \\
34,27 \\
10,11 \\
\end{array}$ \\
\hline
\end{tabular}


TABELA 30 . Anālise de variāncia ${ }^{1}$ para taxa de redução granulométrica da turfa.

\begin{tabular}{lrrrrr}
\hline Causa de variação & G.L. & $\begin{array}{c}\text { Soma de } \\
\text { quadrados }\end{array}$ & $\begin{array}{c}\text { Quadrado } \\
\text { médio }\end{array}$ & $F$ \\
\hline Temperat. final (A) & 4 & 0,30394467 & 0,0759861 & $6,69 * *$ \\
Taxa aquecimento (B) & 2 & 0,61692229 & 0,3084611 & $27,17 * *$ \\
Tempo permanência (C) & 1 & 0,01031917 & 0,0103192 & $0,91 \mathrm{~ns}$ \\
Interação A x B & 8 & 0,25242757 & 0,0315534 & $2,78 *$ \\
Interação A x C & 4 & 0,03197810 & 0,0039945 & $0,70 \mathrm{~ns}$ \\
Interação B x C & 2 & 0,01165127 & 0,0058256 & $0,51 \mathrm{~ns}$ \\
Interação A x B x C & 8 & 0,03518834 & 0,0043985 & $0,39 \mathrm{~ns}$ \\
- & & 29 & 1,26243142 & 0,04353212 & $3,89 *$ \\
(Tratamentos) & 30 & 0,34063050 & 0,01135435 & \\
Residuo & & &
\end{tabular}

Total

$59 \quad 1,60306192$

Coeficiente de variação $(\%)=15,14$.

1 Obtida de dados transformados em arc seno $\sqrt{\mathrm{x} / 100}$ $\mathrm{ns}=$ não significativo

* = significativo ao nível de $5 \%$ de probabilidade

** = significativo ao nivel de $1 \%$ de probabilidade 
TABELA 31. Resultados do experimento para densidade e porosidade do carvão de turfa.

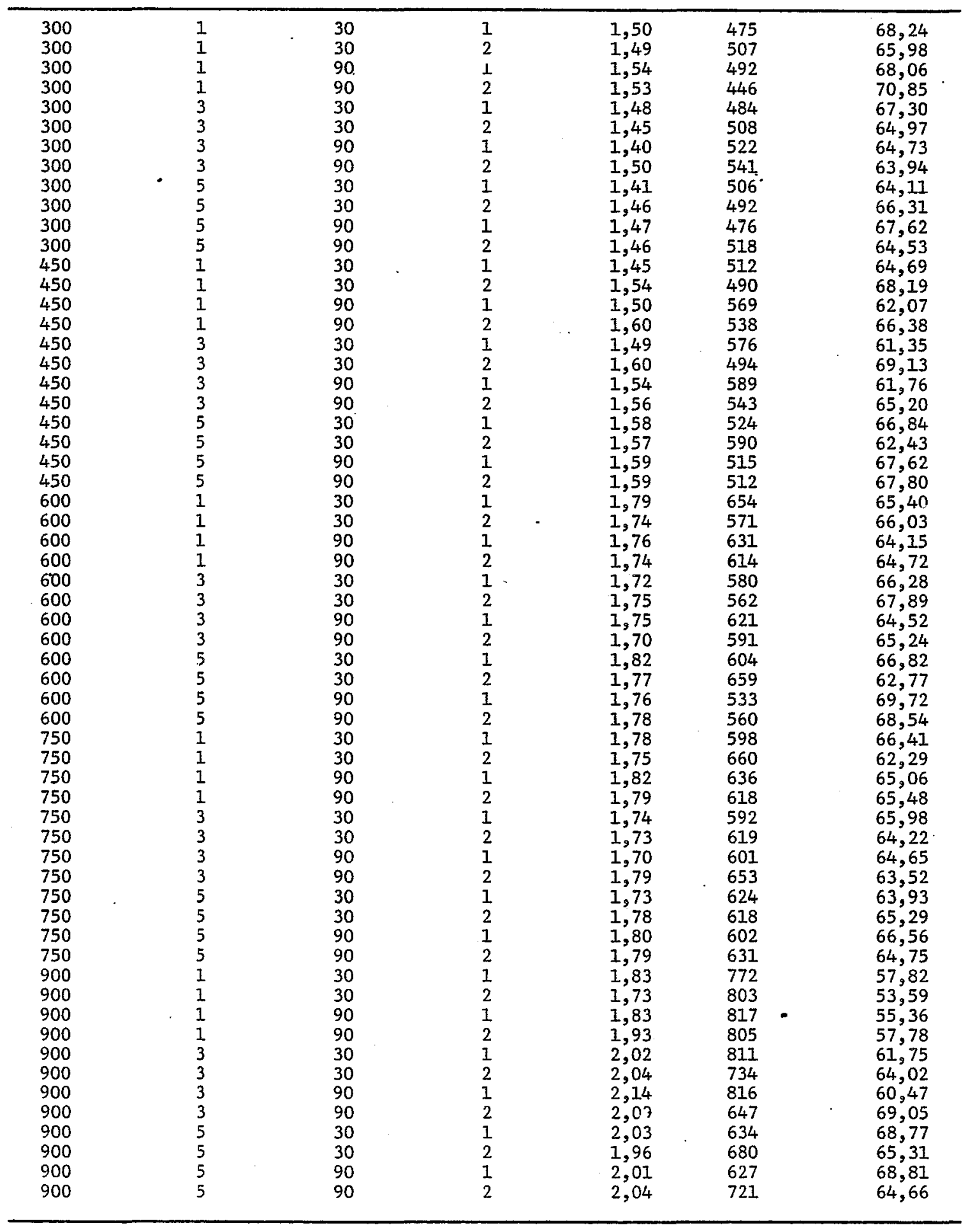


TABELA 32. Análise de variāncia para densidade verdadeira do carvão.

\begin{tabular}{lcccc}
\hline Causa da variação & G.L. & $\begin{array}{c}\text { Soma de } \\
\text { quadrados }\end{array}$ & $\begin{array}{c}\text { Quadrado } \\
\text { médio }\end{array}$ & $F$ \\
\hline Temperat. final (A) & 4 & 1,8783 & 0,469 & $253,14 *$ \\
Taxa aquecimento (B) & 2 & 0,0139 & 0,0069 & $3,74 *$ \\
Tempo permanência (C) & 1 & 0,0070 & 0,0070 & $3,80 \mathrm{~ns}$ \\
Interação A x B & 8 & 0,1625 & 0,0158 & $10,95 *$ \\
Interação A x C & 4 & 0,0130 & 0,0032 & $1,75 \mathrm{~ns}$ \\
Interação B x C & 2 & 0,0012 & 0,0006 & $0,32 \mathrm{~ns}$ \\
Interação A x B x C & 8 & 0,0056 & 0,0007 & $0,38 \mathrm{~ns}$ \\
- & & & & \\
\hline (Tratamentos) & 29 & 2,0815 & 0,0718 & $39,69 *$ \\
Residuo & 30 & 0,0556 & 0,0018 &
\end{tabular}

Total

$59 \quad 2,1372$

Coeficiente de variação $\left(\frac{\circ}{6}\right)=2,52$

$\mathrm{ns}=$ não significativo

* = significativo ao nivel de $5 \%$ de probabilidade

** = significativo ao nivel de $1 \%$ de probabilidade 
TABELA 33. Análise de variância para densidade aparente do carvão.

Causa de variação G.I. $\begin{gathered}\text { Soma de } \\ \text { quadrado }\end{gathered} \begin{gathered}\text { Quadrado } \\ \text { médio }\end{gathered} \quad F$

Temperat. 'final

(A) $4421420,7667 \quad 105355,1917 \quad 65,95 * *$

Taxa aquecimento

$\begin{array}{lllll}\text { (B) } & 2 & 10467,7333 & 5233,8666^{\circ} \quad 3,28 \mathrm{~ns}\end{array}$

Tempo permanência

(C)

$186,4000 \quad 86,4000 \quad 0,05 \mathrm{~ns}$

Interação A X B

$8 \quad 35187,9333$

$4398,4917 \quad 2,75^{*}$

Interação A $\mathrm{x}$ C

$4 \quad 1526,1000$

381,5250

0,24 ns

Interação B x C

$2 \quad 5230,0000$

2615,0000

$1,64 \mathrm{~ns}$

Interação A x B x C

11229,0000

1403,6250

$0,88 \mathrm{~ns}$

(Tratamentos)

$29 \quad 485147,9333$

16729,2390

$10,47 * *$

Residuo

30

47924,0000

1597,4666

Total

$59 \quad 533071,9333$.

Coeficiente de variação $(\%)=6,66$

ns = não significativo

* = significativo ao nivel de $5 \%$ de probabilidade

** = significativo ao nivel de $1 \%$ de probabilidade 
TABELA 34. Análise de variância para porosidade do carvão. de turfa.

\begin{tabular}{|c|c|c|c|c|}
\hline Causa de variação & G.L. & $\begin{array}{l}\text { Soma de } \\
\text { quadrados }\end{array}$ & $\begin{array}{l}\text { Quadrado } \\
\text { médio }\end{array}$ & $F$ \\
\hline Temperat. final (A) & 4 & 125,3365 & 31,3341 & $5,59 * *$ \\
\hline Taxa aquecimento (B) & 2 & 50,4120 & 25,2060 & $4,49 *$ \\
\hline Tempo permanēncia (C) & 1 & 1,4695 & 1,4595 & $0,26 \mathrm{~ns}$ \\
\hline Interação $\mathrm{A} \times \mathrm{B}$ & 8 & 231,5220 & 28,9402 & $5,16 * *$ \\
\hline Interação $\mathrm{A} \times \mathrm{C}$ & 4 & 1,9351 & 0,4837 & $0,09 \mathrm{~ns}$ \\
\hline Interação $B \times C$ & 2 & 19,664 & 9,8323 & $1,75 \mathrm{~ns}$ \\
\hline Interação $\mathrm{A} \times \mathrm{B} \times \mathrm{C}$ & 8 & 36,2635 & 4,5329 & $0,81 \mathrm{~ns}$ \\
\hline (Tratamentos) & 29 & 466,6034 & 16,0897 & $2,87 * *$ \\
\hline Residuo & 30 & 168,2271 & 5,6075 & \\
\hline \multirow[t]{2}{*}{ Total } & 59 & 634,8305 & & \\
\hline & Coe & iente de & riação (\%) & 3,64 \\
\hline \multicolumn{5}{|c|}{$n s$ = não significativo } \\
\hline
\end{tabular}


TABELA 35. Resultados do experimento para poder calorífico superior e com posição química do carvão de turfa.

\begin{tabular}{|c|c|c|c|c|c|c|c|}
\hline Temperatura & $\begin{array}{l}\text { Taxa de } \\
\text { aquecimento } \\
\left({ }^{\circ} / \text { min }\right)\end{array}$ & $\begin{array}{l}\text { Tempo de } \\
\text { permanencia } \\
\quad(\text { min })\end{array}$ & Repetiçāo & $\begin{array}{c}\text { Poder } \\
\text { calorifico } \\
\text { superior } \\
(\mathrm{kcal} / \mathrm{kg}) \\
\end{array}$ & $\begin{array}{l}\text { Teor } \\
\text { matérias } \\
\text { voláteis } \\
(\%) \\
\end{array}$ & $\begin{array}{l}\text { Teor } \\
\text { cinzas } \\
(\%)\end{array}$ & $\begin{array}{l}\text { Teor } \\
\text { carbonn } \\
\text { fixo } \\
(\%) \\
\end{array}$ \\
\hline $\begin{array}{l}300 \\
300 \\
300 \\
300 \\
300 \\
300 \\
300 \\
300 \\
300 \\
300 \\
300 \\
300 \\
450 \\
450 \\
450 \\
450 \\
450 \\
450 \\
450 \\
450 \\
450 \\
450 \\
450 \\
450 \\
600 \\
600 \\
600 \\
600 \\
600 \\
600 \\
600 \\
600 \\
600 \\
600 \\
600 \\
600 \\
750 \\
750 \\
750 \\
750 \\
750 \\
750 \\
750 \\
750 \\
750 \\
750 \\
750 \\
750 \\
900 \\
900 \\
900 \\
900 \\
900 \\
900 \\
900 \\
900 \\
900 \\
900 \\
\end{array}$ & 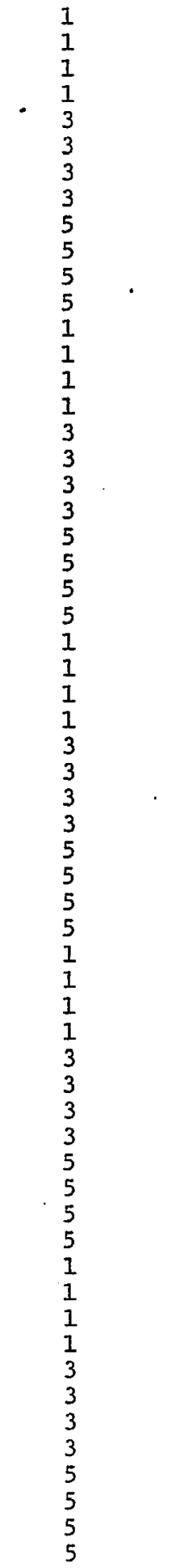 & 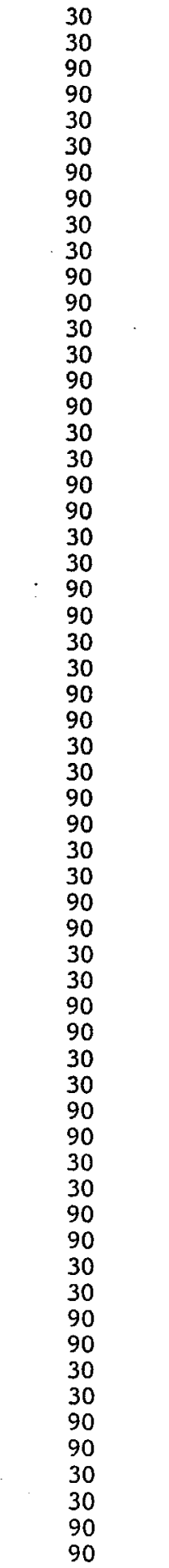 & 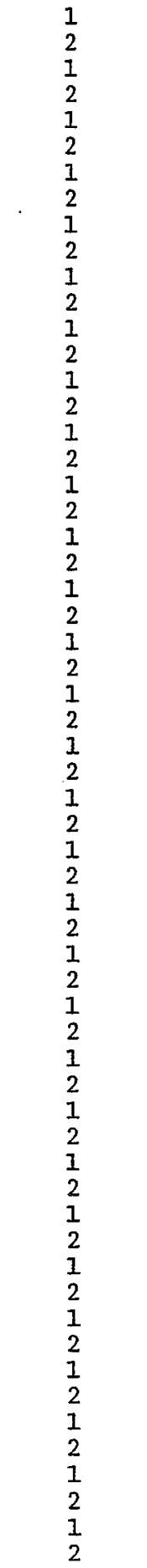 & $\begin{array}{l}5117,0 \\
4971,7 \\
5078,8 \\
5137,3 \\
5064,6 \\
5304,3 \\
5176,2 \\
5343,8 \\
5119,8 \\
5156,6 \\
5185,8 \\
5112,7 \\
5515,6 \\
5488,1 \\
5914,0 \\
5911,1 \\
5451,3 \\
5823,1 \\
5734,1 \\
5578,0 \\
5857,3 \\
5772,8 \\
5458,2 \\
6075,3 \\
6466,2 \\
6305,5 \\
6889,1 \\
6880,4 \\
6590,8 \\
6408,2 \\
6470,0 \\
6994,6 \\
6435,6 \\
5836,5 \\
6842,5 \\
6521,2 \\
6266,1 \\
6643,6 \\
6879,7 \\
6283,0 \\
6850,2 \\
6588,4 \\
6644,8 \\
6833,1 \\
7268,7 \\
6680,5 \\
6810,1 \\
6735,2 \\
6581,7 \\
6832,8 \\
6829,0 \\
6892,1 \\
6664,7 \\
6212,9 \\
6803,4 \\
6628,3 \\
6833,7 \\
6441,4 \\
6761,3 \\
6865,1\end{array}$ & 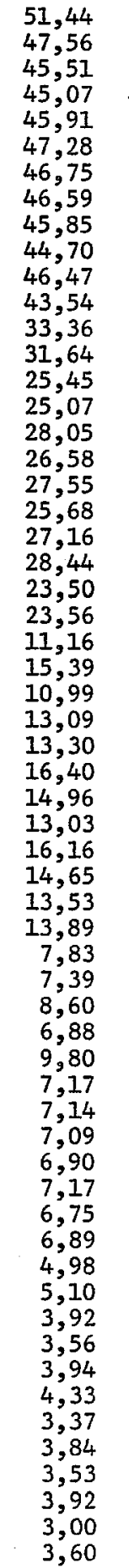 & $\begin{array}{l}20,08 \\
20,75 \\
24,37 \\
23,55 \\
24,27 \\
22,43 \\
20,59 \\
20,86 \\
20,53 \\
23,91 \\
18,70 \\
23,02 \\
22,26 \\
23,92 \\
32,33 \\
30,35 \\
31,09 \\
29,17 \\
27,11 \\
25,28 \\
24,79 \\
23,48 \\
29,47 \\
34,17 \\
36,58 \\
37,52 \\
36,48 \\
29,10 \\
25,30 \\
28,54 \\
27,50 \\
35,14 \\
30,27 \\
31,62 \\
30,98 \\
29,32 \\
36,90 \\
42,40 \\
38,15 \\
38,54 \\
37,35 \\
40,74 \\
38,05 \\
38,32 \\
39,73 \\
31,30 \\
36,00 \\
37,39 \\
39,90 \\
39,28 \\
37,48 \\
36,92 \\
41,53 \\
39,04 \\
32,73 \\
32,54 \\
33,80 \\
35,54 \\
36,51 \\
34,80\end{array}$ & 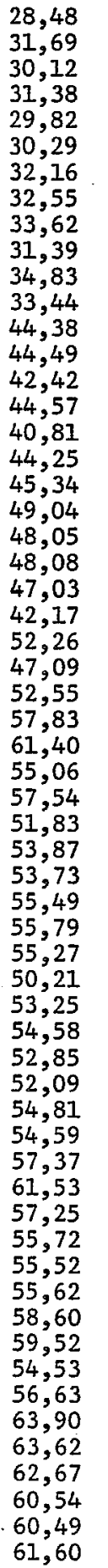 \\
\hline
\end{tabular}


TABELA 36. Análise de variância para poder calorifico superioŕ do carvão de turfa.

\begin{tabular}{|c|c|c|c|c|}
\hline Causa da variação & G.I. & $\begin{array}{l}\text { Soma de } \\
\text { quadrado }\end{array}$ & $\begin{array}{l}\text { Quadrado } \\
\text { médio }\end{array}$ & F \\
\hline Temperat. final (A) & 4 & 23416673,476 & 5854168,369 & $119,94 * *$ \\
\hline Taxa aquecim. (B) & 2 & 29716,087 & 14858,043 & $0,30 \mathrm{~ns}$ \\
\hline Tempo perman. (C) & 1 & 340340,953 & 340340,953 & $6,97 *$ \\
\hline Interação $A \times B$ & 8 & 501150,383 & 62643,797 & $1,28 \mathrm{~ns}$ \\
\hline Interação $A \times C$ & 4 & 301415,240 & 75353,810 & $1,54 \mathrm{~ns}$ \\
\hline Interação B X C & 2 & 49988,811 & 24994,405 & $0,51 \mathrm{~ns}$ \\
\hline Interação A x B x C & 8 & 189221,032 & 23652,629 & $0,48 \mathrm{~ns}$ \\
\hline (Tratamentos) & 29 & 24828505,983 & 856155,378 & $17,84 * *$ \\
\hline Residuo & 30 & 1464277,925 & 48809,264 & \\
\hline
\end{tabular}

Total

$59 \quad 26292783,908$

Coeficiente de variação $(\%)=3,59$

ns = não significativo

* = significativo ao nivel de $5 \%$ de probabilidade

** = significativo ao nivel de $1 \%$ de probabilidade 
TABELA 37. Análise de variância para teor de matérias voláteis do carvão.

\begin{tabular}{lrrrrc}
\hline Causa dá variaça & G.L. & $\begin{array}{r}\text { soma de } \\
\text { quadrado }\end{array}$ & $\begin{array}{c}\text { Quadrado } \\
\text { médio }\end{array}$ & $F$ \\
\hline Temperat. final (A) & 4 & 14394,0987 & 3598,5246 & $2441,86 * *$ \\
Taxa aquecim. (B) & 2 & 10,1051 & 5,2525 & $3,56 *$ \\
Tempo perman. (C) & 1 & 37,1614 & 37,1614 & $25,22 * *$ \\
Interação A X B & 8 & 34,7979 & $4,3497$. & $2,95 *$ \\
Interação A x C & 4 & 24,9983 & 6,2495 & $4,24 *$ \\
Interação B x C & 2 & 11,6431 & 5,2815 & $3,95 *$ \\
Interação A x B x C & 8 & 22,9154 & $2,8644$. & $1,94 \mathrm{~ns}$
\end{tabular}

(Tratamentos)

29

14536,1209

$501,2455^{\circ} 340,13^{* *}$

Resíảuo

30

44,2105

1,4737

Total

Coeficiente de variação $(\%)=6,14$

$\mathrm{ns}=$ não significativo

* = significativo ao nivel de $5 \%$ de probabilidade ** = significativo ao nivel de $1 \%$ de probabilidade 
TABELA 38. Anālise de variância para teor de cinzas do carvão de turfa.

\begin{tabular}{|c|c|c|c|c|}
\hline Causa da variação & G.I. & $\begin{array}{l}\text { Soma de } \\
\text { quadrado }\end{array}$ & $\begin{array}{l}\text { Quadrado } \\
\text { mêdio }\end{array}$ & F \\
\hline Temperat. final $(A)$ & 4 & 2073,2111 & 518,3027 & $94,57 * *$ \\
\hline Taxa aquecim. (B) & 2 & $45,5354^{\circ}$ & 22,7676 & $4,15 *$ \\
\hline Tempo perman. (C) & 1 & 0,0499 & 0,0498 & $0,01 \mathrm{~ns}$ \\
\hline Interação $A \times \mathrm{B}$ & 8 & 71,3832 & 8,9229 & $1,63 \mathrm{~ns}$ \\
\hline Interação $\mathrm{A} \times \mathrm{C}$ & 4 & $75,812 I$ & 18,9530 & $3,46 *$ \\
\hline Interação $B \times C$ & 2 & 37,5116 & 18,7558 & $3,42 *$ \\
\hline Interação $\mathrm{A} \times \mathrm{B} \times \mathrm{C}$ & 8 & 157,7191 & 19,7148 & $3,60 *$ \\
\hline \multirow{2}{*}{\multicolumn{5}{|c|}{ (montomantor }} \\
\hline (Tratamentos) & & & & $15,49 * *$ \\
\hline Residuo & 30 & 164,4136 & 5,4804 & \\
\hline \multicolumn{5}{|c|}{ 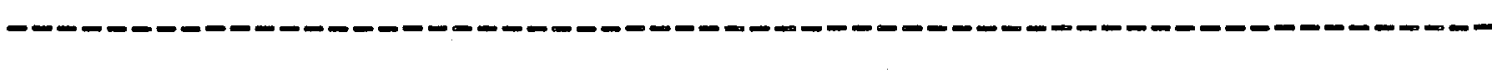 } \\
\hline Total & 59 & 2625,63602 & & \\
\hline
\end{tabular}

Coeficiente de variação $(\%)=7,51$

$\mathrm{ns}=$ não significativo

* = significativo ao nivel de $5 \%$ de probabilidade

** = significativo ao nivel de $1 \%$ de probabilidade 
TABELA 39. Análise de variância para teor de carbono fixo do carvão de turfa.

\begin{tabular}{|c|c|c|c|c|}
\hline Causa da variação & G.I. & $\begin{array}{l}\text { Soma de } \\
\text { quadrado }\end{array}$ & $\begin{array}{l}\text { Quadrado } \\
\text { médio }\end{array}$ & $F$ \\
\hline Temperat. final (A) & 4 & $5897,7120:$ & 1474,4280 . & $341,27 * *$ \\
\hline Taxa aquecim. (B) & 2 & 104,3005 & 52,1502 & $12,07 * *$ \\
\hline Tempo perman. (C) & 1 & 27,7032 : & 27,7032 & $6,41 *$ \\
\hline Interação $\mathrm{A} \times \mathrm{B}$ & 8 & 44,6627 & 5,5828 & $1,29 \mathrm{~ns}$ \\
\hline Interação $A \times C$ & 4 & 25,7967 & 6,4491 & $1,49 \mathrm{~ns}$ \\
\hline Interação $B \times C$ & 2 & 32,5153 & 16,2576 & $3,46 *$ \\
\hline Interação A $\times$ B $\times$ & 8 & 98,4262 & 12,3032 & $2,85^{*}$ \\
\hline (Tratamentos) & 29 & 6233,1166 & 214,8660 & $47,73 * *$ \\
\hline Residuo & 30 & 129,6106 & 4,3203 & \\
\hline
\end{tabular}

Total

59

6360,7272

Coeficiente de variação $\left(\frac{\circ}{6}\right)=4,23$

ns = não significativo

* = significativo ao nivel de 5\% de probabilidade

** = significativo ao nível de $1 \%$ de probabilidade 